\title{
STRATEGI GURU DALAM MEMBENTUK KARAKTER \\ KEMANDIRIAN BELAJAR SISWA BERBKEBUTUHAN KHUSUS \\ MELALUI METODE PEMBIASAAN DI SDLB TUNARUNGU NEGERI TULUNGAGUNG
}

\section{TESIS}

Oleh:

Faidl Mabrurotul Hasanah

NIM 16761024

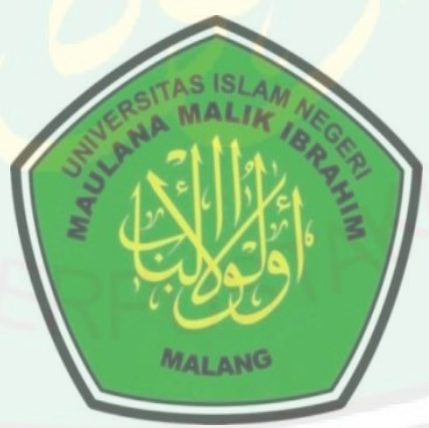

MAGISTER PENDIDIKAN GURU MADRASAH IBTIDAIYAH PASCASARJANA

UNIVERSITAS ISLAM NEGERI MAULANA MALIK IBRAHIM MALANG 


\section{STRATEGI GURU DALAM MEMBENTUK KARAKTER \\ KEMANDIRIAN BELAJAR SISWA BERBKEBUTUHAN KHUSUS \\ MELALUI METODE PEMBIASAAN DI SDLB TUNARUNGU NEGERI \\ TULUNGAGUNG}

\section{Tesis}

Diajukan kepada

Pascasarjana Universitas Maulana Malik Ibrahim Malang

Untuk memenuhi salah satu persyaratan dalam menyelesaika

Program Magister Pendidikan Guru Madrsah Ibtidaiyah

Oleh:

Faidl Mabrurotul Hasanah

NIM 16761024

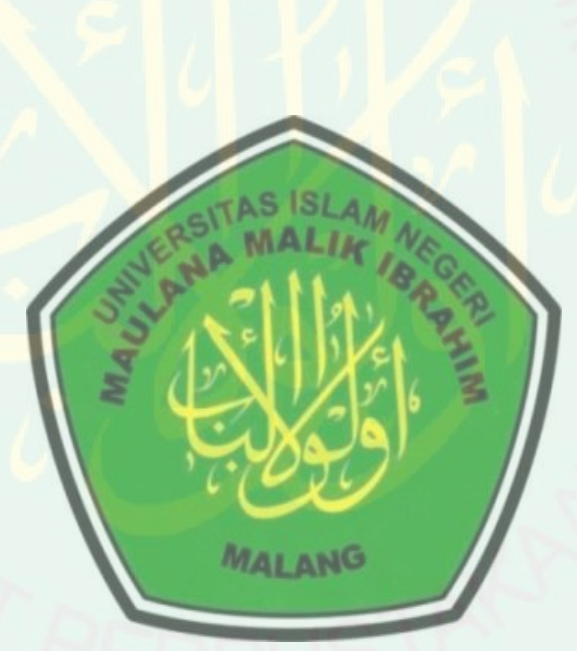

MAGISTER PENDIDIKAN GURU MADRASAH IBTIDAIYAH PASCASARJANA

UNIVERSITAS ISLAM NEGERI MAULANA MALIK IBRAHIM MALANG

2018 


\section{LEMBAR PERSETUJUAN UJIAN TESIS}

Tesis dengan judul Strategi Guru Dalam Membentuk Karakter Kemandirian

Belajar Siswa Berkebutuhan Khusus Melalui Pembiasaan Di SDLB

Tunarungu Negeri Tulungagung

Ini telah diperiksa dan disetujui untuk diuji,

Malang, 10 Desember 2018

Pembimbing 1

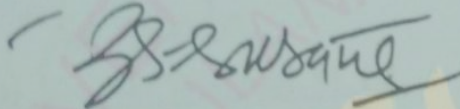

H. Djoko Susanto, M.Ed, Ph.D

NIP, 196705292000031001

Malang, 11 Desember 2018

Pembimbing II

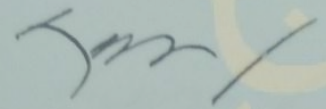

Dr. Langgeng Budianto. M.Pd

NIP. 197110142003121001

Malang, 11 Desember 2018

Mengetahui,

Ketua Program Magister Pendidikan Guru Madrasah Ibtidaiyah

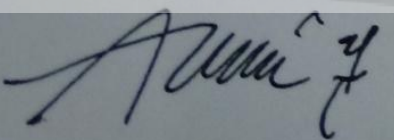

Dr. H. Ahmad Fatah Yasin, M.Ag.

NIP. 1967122201998031002 


\section{LEMBAR PENGESAHAN}

Tesis dengan judul Strategi Guru Dalam Membentuk Karakter Kemandirian

Belajar Siswa Berkebutuhan Khusus Melatui Pembiasaan Di SDLB

Tunarungu Negeri Tulungagung ini telah dan dipertahankan di depan sidang

dewan penguji pada tanggal 21 Desember 2018.

Dewan Penguji,

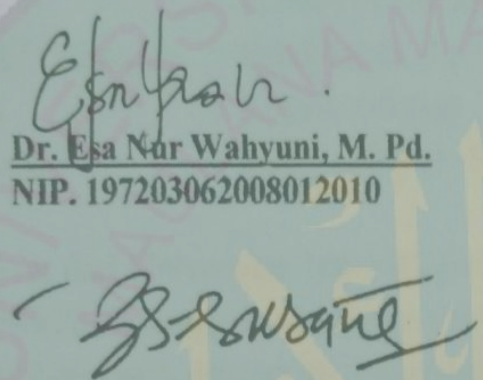

H. Djoko Susanto, M.Ed, Ph.D. NIP. 196705292000031001

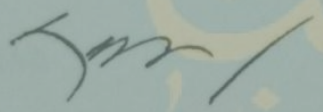

Dr. Langgeng Budianto. M.Pd. NIP. 197110142003121001

Penguji Utama

Anggota

Anggota

Mengetahui,

Direktur Pascasarjana

UIN Maulana Malik Ibrahim Malang

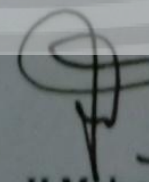

Prof. Dr. H.Mullyadi, M.Pd.I.

NIP. 195507171982031005 


\section{PEDOMAN TRANSLITERASI ARAB LATIN}

Penulisan transliterasi Arab-Latin dalam skripsi ini menggunakan pedoman transliterasi berdasarkan keputusan bersama Menteri Agama RI dan Menteri Pendidikan dan Kebudayaan RI no. 158 tahun 1987 dan no. 0543 b/U/1987 yang secara garis besar dapat diuraikan sebagai berikut:

Huruf
$1=\mathrm{a}$
$j=Z$
$3=\mathrm{q}$
$\varphi=b$
s) $=\mathrm{k}$
$=\mathrm{t}$
ش $=$ sy
$J=1$
$\star=$ ts
, $=\mathrm{m}$
ج $=\mathrm{j}$
ن $=\mathrm{n}$
$\tau=\underline{h}$
, $=\mathrm{w}$
$\dot{\tau}=\mathrm{kh}$
$ه=h$
, $=\mathrm{d}$
j $=\mathrm{dz}$
$ض=\mathrm{dl}$
b $=$ th
b $=\mathrm{zh}$
$\varepsilon=$
$\dot{\varepsilon}=\mathrm{gh}$
s $=y$
, $=\mathrm{r}$
$\dot{\omega}=\mathrm{f}$

\section{Vokal Panjang}

$\begin{array}{ll}\text { Vokal (a) panjang } & =\hat{\mathrm{a}} \\ \text { Vokal (i) panjang } & =\hat{\mathrm{i}} \\ \text { Vokal (u) panjang } & =\hat{\mathrm{u}}\end{array}$

\section{Vokal Dipotong}

$$
\begin{aligned}
& \hat{1}=\mathrm{aw} \\
& \mathrm{i}=\mathrm{ay} \\
& \mathrm{i}=\hat{\mathrm{u}} \\
& \mathrm{i}=\hat{\mathrm{i}}
\end{aligned}
$$




\section{SURAT PERNYATAAN ORISINALITAS PENELITIAN}

Saya yang bertanda tangan di bawah ini:

Nama $\quad$ : Faidl Mabrurotul Hasanah

NIM $\quad: 16761024$

Program Studi : Magister Pendidikan Guru Madrasah Ibtidaiyah

Judul Tesis : Strategi Guru Dalam Membentuk Karakter Kemandirian Belajar

Siswa Berkebutuhan Khusus Melalui Metode Pembiasaan Di

SDLB Tunarungu Negeri Tulungagung

Menyatakan dengan sebenar-benarnya bahwa dalam penelitian saya ini tidak terdapat unsur-unsur penjiplakan karya penelitian atau karya ilmiah yang pernah dilakukan atau dibuat oleh orang lain, kecuali secara tertulis dikutip dalam naskah ini dan disebutkan dalam sumber kutipan dan daftar rujukan.

Apabila dikemudian hari ternyata penelitian ini terbukti terdapat unsurunsur penjiplakan dan ada klaim dari pihak lain, maka saya bersedia untuk diproses sesuai dengan peraturan perundang-undangan yang berlaku.

Demikian surat pernyataan ini dibuat dengan sebenarnya dan tanpa paksaan dari siapapun.

Malang, 14 Desember 2018

Hormat saya,

Faidl Mabrurotul Hasanah 


\section{KATA PENGANTAR}

Segala puji syukur bagi Allah SWT. Yang telah melimpahkan rahmat, hidayah, dan taufik-Nya kepada seluruh umat manusia, sehingga kita tetap Iman dan Islam, serta komitmen sebagai insan yang haus akan ilmu pengetahuan.

Tesis ini disusun untuk memenuhi tugas akhir, sebagaimana syarat yang harus dipenuhi dalam jenjang perkuliahan di pascasarjana khususnya di Universitas Islam Negeri Maulana Malik Ibrahim Malang.

Selesainya penyusunan Tesis berkat bimbingan dari dosen yang sudah ditetapkan, dan juga berkat bantuan dari beberapa pihak. Oleh karena itu, sudah sepatutnya penulis menyampaikan ucapan terima kasih kepada:

1. Bapak Prof. Dr. Abdul Haris, M.Ag selaku Rektor Universitas Islam Negeri Maulana Malik Ibrahim Malang yang telah memberikan izin kepada penulis untuk menyusun Tesis.

2. Bapak Prof. Dr. H. Mulyadi, M.Pd.I selaku Direktur Pascasarjana yang selalu memberikan dorongan semangat dalam mengemban ilmu pengetahuan selama perkuliahan.

3. Bapak Dr. H. Ahmad Fatah Yasin,, M.Ag. Selaku Ketua Program Studi Magister Pendidikan Guru Madrasah Ibtidaiyah

4. Bapak H. Djoko Susanto, M.Ed, Ph.D. selaku dosen Pembimbing I dan bapak

Dr. H. Langgeng Budianto, M. Pd. Selaku pembimbing II yang telah membimbing, memberikan saran, kritik dan koreksinya dalam penulisan tesis ini. 
5. Segenap Bapak dan Ibu Dosen Pascasarjana Universitas Islam Negeri Maulana Malik Ibrahim Malang yang telah berjasa menghantarkan penulis untuk mengetahui arti pentingnya ilmu pengetahuan.

6. Bapak Sudarminto Selaku Kepala Sekolah Dasar Luar Biasa B Negeri Tulungagung yang telah memberikan izin kepada penulis untuk melakukan penelitian.

7. Ibu tercinta yang telah memberikan bimbingan, dukungan moral dan spiritual selama studi, serta senantiasa memberikan nasehat serta kasih sayangnya yang tidak ternilai harganya dan juga teruntuk suamiku tercinta yang sudah memberikan dukungan baik material dan non material.

8. Teman-teman angkatan tahun 2016/2017 program Studi Magister Pendidikan Guru Madrasah Ibtidaiyah yang selalu ada dalam kebersamaan dan bantuannya, baik suka maupun duka selama ini, serta memberikan motivasi.

Dengan penuh harapan, semoga jasa kebaikan mereka diterima Allah SWT. Dan tercatat sebagai amal shalih. Jazakumullah khoirul jazae. Akhirnya, karya ini penulis suguhkan kepada segenap pembaca dengan harapan adanya saran dan kritik yang bersifat konstruktif demi pengembangan dan perbaikan, serta pengembangan lebih sempurna dalam kajian-kajian pendidikan Islam. Semoga karya ini bermanfaat dan mendapat ridho Allah SWT. Aamiin.

Malang, 14 Desember 2018

Penulis

Faidl Mabrurotul Hasanah 


\section{DAFTAR ISI}

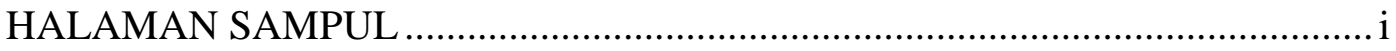

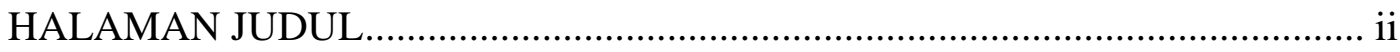

LEMBAR PERSETUJUAN...............................................................................

LEMBAR PENGESAHAN …............................................................. iv

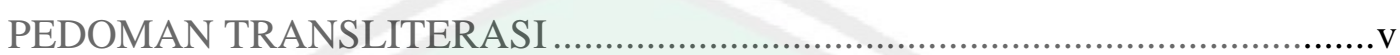

PERNYATAAN KEASLIAN ............................................................ vi

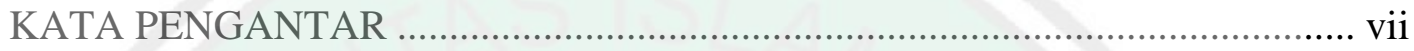

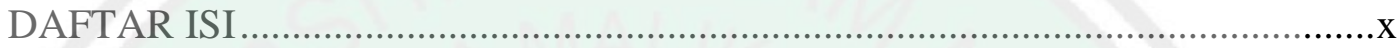

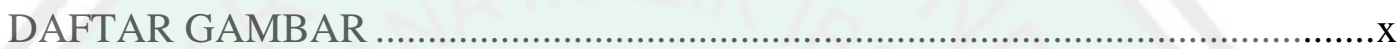

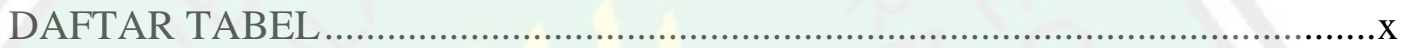

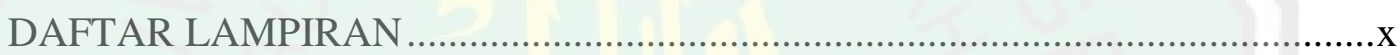

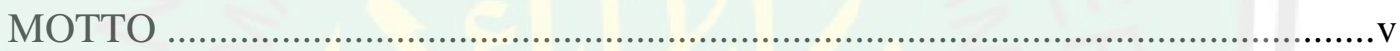

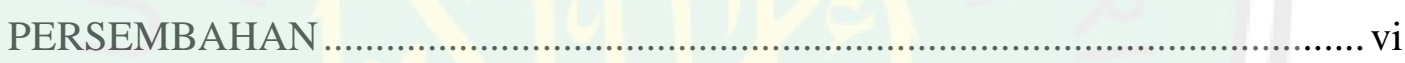

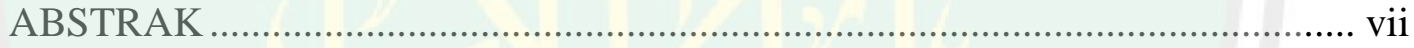

BAB I PENDAHULUAN

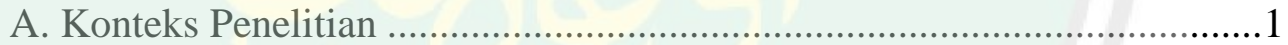

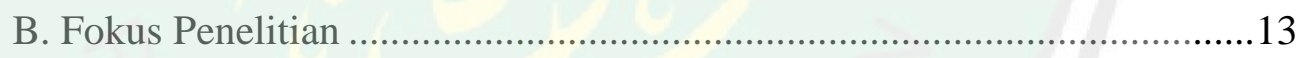

C. Tujuan Penelitian.............................................................................. 14

D. Manfaat Penelitian........................................................................... 14

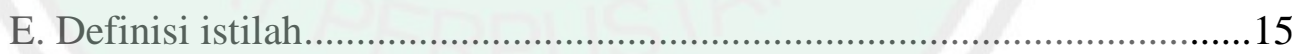

F. Sistematika Pembahasan ..................................................................... 17

BAB II KAJIAN PUSTAKA

A. Pendidikan Karakter .......................................................................20

1. Pengertian Pendidikan Karakter....................................................20

2. Tujuan Pendidikan Karakter ...........................................................21

3. Fungsi Pendidikan Karakter .............................................................22

4. Jenis-Jenis Pendidikan Karakter ....................................................22

5. Tahapan dalam Pendidikan Karakter ................................................23 


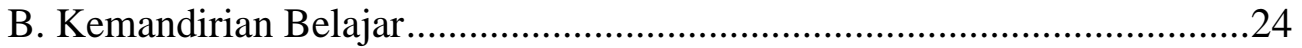

1. Pengertian Kemandirian Belajar ........................................................24

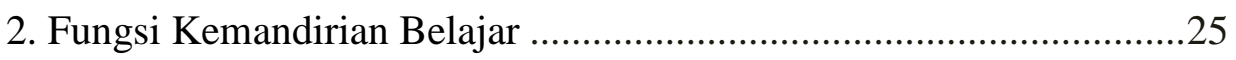

3. Faktor-faktor yang Mempengaruhi Kemandirian Belajar...................25

4. Indikator Kemandirian Belajar...........................................................2

5. Langkah-Langkah Menciptakan Kemandirian Belajar ........................29

6. Pendidikan Karakter Kemandirian di Sekolah .......................................29

C. Dampak dalam Pendidikan Karakter .........................................................32

D. Anak Berkebutuhan Khusus.....................................................................

1. Pengertian Anak Berkebutuhan Khusus ................................................32

2. Jenis-Jenis Anak Berkebutuhan Khusus ...............................................33

3. Penyebab Anak Berkebutuhan Khusus ...................................................35

E. Metode Pembiasaan ...............................................................................36

1. Pengertian Metode Pembiasaan ..........................................................36

2. Landasan Metode Pembiasaan .................................................................39

3. Dasar dan Tujuan Pembiasaan..................................................................40

4. Bentuk-bentuk Pembiasaan ...................................................................

5. Kelebihan dan Kekurangan Metode Pembiasaan ..................................42

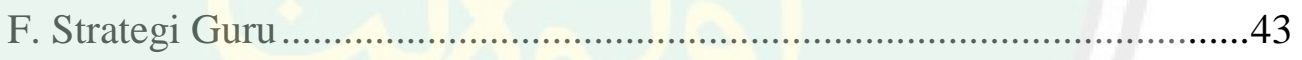

1. Pengertian Strategi Guru ....................................................................

2. Strategi Guru dalam Implementasi Pendidikan Karakter ....................46

G. Strategi Guru dalam Perspektif Islam ......................................................51

H. Pendidikan Karakter dalam Perspektif Islam .............................................52

I. Kerangka Pikir Penelitian ...........................................................................53

\section{BAB III METODE PENELITIAN}

A. Pendekatan dan Jenis Penelitian ..............................................................54

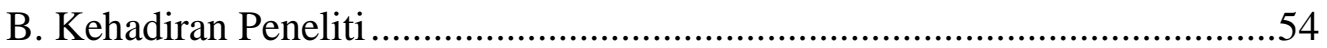

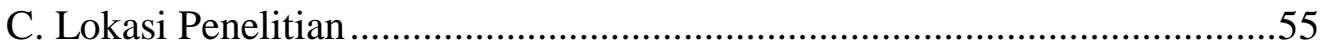

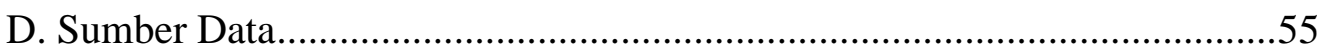

E. Teknik Pengumpulan Data …………………………………....................56

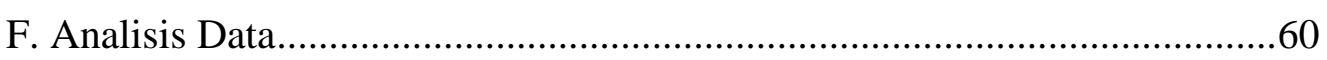

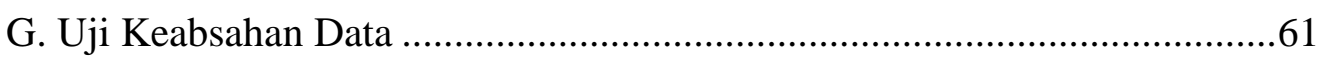




\section{BAB IV PAPARAN DATA DAN HASIL PENELITIAN}

A. Paparan Data .65

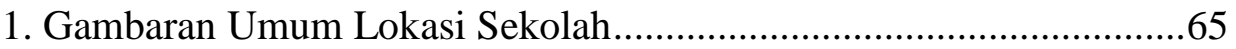

2. Visi Misi dan Tujuan Sekolah..........................................................66

3. Jumlah Guru dan Tenaga Pendidik ..................................................66

4. Jumlah Peserta Didik dan Jumlah Kelas ..........................................67

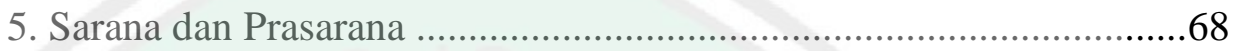

B. Hasil Penelitian...

1. Strategi Guru Dalam Membentuk Karakter Kemandirian Belajar

Siswa Berkebutuhan Khusus melalui metode pembiasaan di SDLB

Tunarungu Negeri Tulungagung.

2. Strategi Guru Dalam Pelaksanaan Pembentukan Karakter

Kemandirian Belajar Siswa Berkebutuhan Khusus melalui metode pembiasaan di SDLB Tunarungu Negeri Tulungagung

3. Dampak Pembentukan Karakter Kemandirian Belajar Siswa Berkebutuhan Khusus melalui metode pembiasaan di SDLB Tunarungu Negeri Tulungagung.

BAB V PEMBAHASAN

A. Strategi Guru Dalam Membentuk Karakter Kemandirian Belajar Siswa Berkebutuhan Khusus di SDLB B Negeri Tulungagung. .80

B. Strategi Guru Dalam Pelaksanaan Pembentukan Karakter Kemandirian Belajar Siswa Berkebutuhan Khusus di SDLB B Negeri

Tulungagung.

C. Dampak Pembentukan Karakter Kemandirian Belajar Siswa

Berkebutuhan Khusus di SDLB B Negeri Tulungagung .86

BAB VI PENUTUP

A. Kesimpulan .88

B. Implikasi

C. Saran .90

\section{DAFTAR RUJUKAN}




\section{DAFTAR GAMBAR}

Gambar

Halaman

Gambar 1. Kerangka Pikir Penelitian ....................................53

Gambar 2. Prosedur Penelitian ..........................................62 


\section{DAFTAR TABEL}

Tabel

Halaman

Tabel 1. Dokumentasi Yang Diperlukan ...........................................................58

Tabel 2. Keterkaitan Data Sumber Data dan Pengumpulan Data.........................59

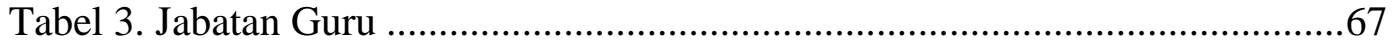

Tabel 4. Jumlah Peserta Didik ..........................................................................68

Tabel 5. Sarana dan Prasarana ..........................................................................69 


\section{DAFTAR LAMPIRAN}

Daftar

Halaman

1. Visi dan Misi ......................................................... 97

2. Tata Tertib Sekolah ...................................................... 98

3. Tata Tertib Kelas .................................................... 101

4. Instrumen Wawancara Untuk Kepala Sekolah ...................... 103

5. Instrumen Wawancara Untuk Guru dan Wali Kelas ................... 105

6. Pedoman Pengumpulan Data ........................................ 106

7. Lembar Observasi Sarana dan Prasarana ............................... 109

8. Daftar Nama-nama Guru .......................................... 110

9. Lembar Wawancara .................................................. 111

10. Foto-foto ......................................................... 117

11. Surat Keterangan Penelitian ..................................... 119

12. Biodata Mahasiswa ................................................ 120 


\section{Motto}

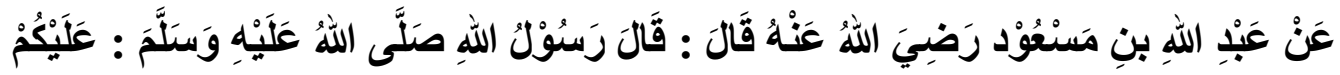

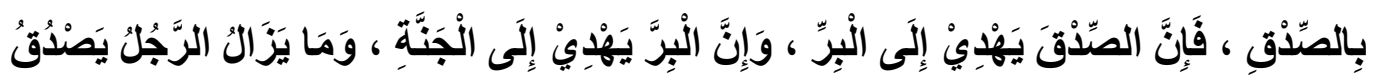

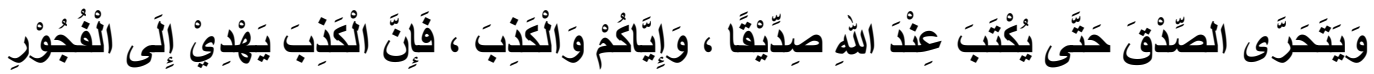

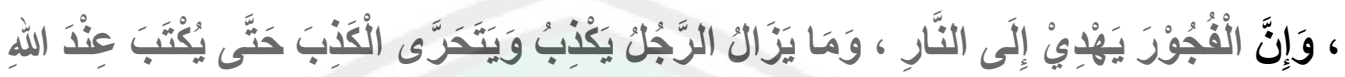
كَذََّبًا

Diriwayatkan dari 'Abdullah bin Mas'ud ra, Rasulullah saw. bersabda, "Hendaklah kamu berlaku jujur karena kejujuran menuntunmu pada kebenaran, dan kebenaran menuntunmu ke surga. Dan sesantiasa seseorang berlaku jujur dan selalu jujur sehingga dia tercatat di sisi Allah Swt. sebagai orang yang jujur. Dan hindarilah olehmu berlaku dusta karena kedustaan menuntunmu pada kejahatan, dan kejahatan menuntunmu ke neraka. Dan seseorang senantiasa berlaku dusta dan selalu dusta sehingga dia tercatat di sisi Allah Swt. sebagai pendusta." (H.R. Muslim) 


\section{PERSEMBAHAN}

Teriring dzikir dan do ${ }^{\text {ee }}$ penuh harap Kepada-Mu Ya Allah SWT. Sebagai ibadahku dalam menuntut ilmu atas perintah-Mu dan atas segala Ridho-Mu yang selalu mengiringi setiap langkahku.

Atas nama cinta setulus hati karya ini ku persembahkan kepada:

Almarhum Ayah tercinta (Alm H. Iskandar), Ibunda tercinta (Zuriyah), Suamiku tercinta (Mohammad Nasrudin) kakak-kakakku (M. Taufiq, Isna Lutfiatur dan Fita), keponakanku (Izza dan Fatih) dan segenap keluarga besarku yang selalu sabar membimbing dan memberikan jutaan kasih sayangnya selalu mendo'akan dengan penuh ikhlas dan memberi motivasi padaku untuk berusaha selalu memberikan yang terbaik.

Para Guru dan Dosen yang telah memberikan ilmu tiada henti semoga untaian do'a tiada jenuh teralir hingga yaumul akhir amin. 


\begin{abstract}
ABSTRAK
Faidl Mabrurotul Hasanah, 2018 strategi guru dalam membentuk karakter kemandirian belajar siswa berkebutuhan khusus melalui metode pembiasaan di SDLB Tunarungu Negeri Tulungagung. Tesis. Program Magister Pendidikan Guru Madrasah Ibtidaiyah. Pascasarjana. Universitas Islam Negeri Maulana Malik Ibrahim Malang. Pembimbing (I) H. Djoko Susanto, M.Ed, Ph.D. Pembimbing (II) Dr. H. Langgeng Budianto, M. Pd.
\end{abstract}

Kata kunci : Strategi, Karakter kemandirian, Siswa Berkebutuhan Khusus, Pembiasaan

Penelitian ini dilatarbelakangi oleh pentingnya penerapan karakter kemandirian belajara siswa berkebutuhan khusus bagian tuna rungu, dimana siswa berkebutuhan khusus membutuhkan penanganan khusus dalam berbagai hal, pada Sekolah Dasar Luar Biasa Tunarungu Negeri Tulungagung ini masih belum semua siswanya mempunyai karakter kemandirian belajar. Dalam hal ini peran kepala sekolah dan guru sangat penting dalam menumbuhkan karakter kemandirian belajar siswa.

Penelitian bertujuan : Pertama mendeskripsikan dan menganalisis strategi guru dalam pembentukan karakter kemandirian belajar siswa berkebutuhan khusus melalui metode pembiasaan di Sekolah Dasar Luar Biasa Tunarungu Negeri Tulungagung. Kedua mendeskripdikan dan menganalisis strategi guru dalam pelaksanaan pembentukan karakter kemandirian belajar siswa berkebutuhan khusus melalui metode pembiasaan di Sekolah Dasar Luar Biasa Tunarungu Negeri Tulungagung. Ketiga mendeskripsikan dampak pembentukan karakter kemandirian belajar siswa berkebutuhan khusus melalui metode pembiasaan di Sekolah Dasar Luar Biasa Tunarungu Negeri Tulungagung.

Penelitian ini menggunakan pendekatan kualitatif dengan teknik pemaparan informan temuan secara deskriptif. Teknik pengumpulan data dalam penelitian ini adalah wawancara, observasi, dan dokumentasi. Teknik analisis datanya menggunakan pengelompokan data, reduksi data dan penarikan kesimpulan dan verifikasi.

Hasil penelitian ini menyimpulkan bahwa strategi guru dalam pembentukan karakter di sekolah dasar melalui metode pembiasaan antara lain setiap bulannya mengadakan lomba mewarnai untuk kelas 1 sampai 3 dan mengadakan lomba memasak dan menyulam untuk kelas 4 sampai 5. Strategi guru dalam pelaksanaan pembentukan karakter siswa melalui metode pembiasaan diantaranya setiap masuk kelas harus bersalaman dengan semua guru, siswa diajarkan untuk menyiapkan peralatan sekolah sendiri, siswa diajarkan untuk membersihkan kelasnya sendiri. Dampak pembentukan karakter kemandirian belajar siswa melalui metode pembiasaan diantaranya siswa jadi bisa mengurus 
kebutuhan sekolahnya sendiri, siswa jadi berani menampilkan bakat yang dimiliki, siswa lebih berani melakukan aktifitasnya sendiri dan terampil dalam berbagai bidang. 


\begin{abstract}
Faidl Mabrurotul Hasanah, 2018 teacher strategy in shaping the character of learning independence of students with special needs through habituation methods at SDLB Tunarungu Negeri Tulungagung. Thesis. Master Program in Madrasah Ibtidaiyah Teacher Education. Postgraduate. Maulana Malik Ibrahim State Islamic University Malang. Advisor (I) H. Djoko Susanto, M.Ed, Ph.D. Advisor (II) Dr. H. Langgeng Budianto, M. Pd.
\end{abstract}

Keywords: Strategy, Character of independence, Students with Special Needs, Habituation.

This research is motivated by the importance of applying the character of learning independence of students with special needs for the deaf part, where students with special needs need special handling in various ways, in this extraordinary elementary school Tulungagung Deaf Deaf still not all students have character of learning independence. In this case the role of the principal and teacher is very important in growing the character of student learning independence.

The research aims: First to describe and analyze the teacher's strategy in forming the character of learning independence of students with special needs through habituation methods in the Extraordinary Elementary School Tunarungu Negeri of Tulungagung, The second describes and analyzes the teacher's strategy in implementing the formation of the character of learning independence for students with special needs through habituation methods in the Extraordinary Elementary School Tunarungu Negeri of Tulungagung, The third describes the impact of the formation of the character of learning independence for students with special needs through habituation methods in the Extraordinary Elementary School Tunarungu Negeri of Tulungagung.

This study used a qualitative approach with the descriptive technique of informant findings. Data collection techniques in this study were interviews, observation, and documentation. Data analysis techniques use grouping data, data reduction and drawing conclusions and verification.

The results of this study conclude that the teacher's strategy in character building in elementary schools includes monthly coloring competitions for grades 1 to 3 and holding cooking and embroidering competitions for grades 4 to 5 . The teacher's strategy in implementing student character building each class must shake hands with all teachers, students are taught to prepare their own school equipment, students are taught to clean their own classes. The impact of the formation of the character of student learning independence includes students being able to take care of their own school needs, students become bold in displaying their talents, students are more daring to do their own activities. 


\section{ملخص البحث}

فأض. ـ1 1 • r. استراتيجية المعلم في تشكيل شخصية الاستقلالية لتعلم الطلاب ذوي الاحتياجات الخاصة من خلال طريقة التعود في المدرسة الابتدائية الحكومية الاستثنائية ( SDLB) تولونغاكونج. الرسالة الماجستير، برنامج الدراسة الماجستير التربية المعلم المدرسة الابتدائية

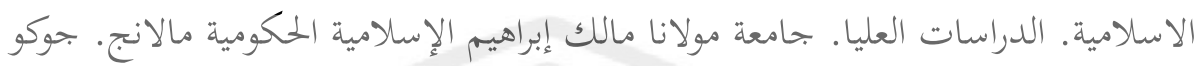
سوسنتو، الحج الماجستير، الدكتور لانغكينج بودينتو، الحج الماجستير

الكلمات الئيسية: استراتيجية ، شخصية ، استقلالية ، الطلاب ذوي احتياجات خاصة، التعود الحلفية البحث هي لاهمية عن تطبيق شخصية الاستقلالية لتعلم الطلاب ذوي الاحتياجات

الخاصة للجزء الأصم ، حيث يمتاجهم إلى معالجة خاصة بطرق مختلفة ، في هذه المدرسة الابتدائية الحكومية الاستثنئية تولونغاكونج هي ليس كل الطلاب لديهم شخصية الاستقلالية. في هذه الحالة ، يكون دور المدير المدرسة والمعلم مهمًا جدًا في تعزيز شخصية الاستقلالية لتعلم الطلاب. بحيث يمكن أن يزيد شخصية الاستقلالية لتعلم الطلاب

يهاف البحث إلى: أولا، وصف وتحليل استراتيجية المعلم في تشكيل شخصية الاستقلالية لتعلم الطلاب ذوي الاحتياجات الخاصة من خلال طريقة التعود في المدرسة الابتدائية الحكومية الاستثنائية تولونغاكونج. ثانيا، وصف وتحليل استراتيجية المعلم في تنفيذ التشكيل شخصية الاستقلالية لتعلم الطلاب ذوي الاحتياجات الخاصة من خلال طريقة التعود في المدرسة الابتدائية الحكومية الاستثنائية تولونغاكونج. ثالثا، يصف الاثر لتشكيل شخصية الاستقلالية لتعلم الطالب ذوي الاحتياجات الخاصة من خلال طريقة التعود في المدرسة الابتدائية الحكومية الاستثائية ( SDLB) تولونغاكونج استخدم هذا البحث فجًا كميًا باستخدام عرض المخبر النتائج وصفيا. كانت تقنيات جمع البيانات في هذت البحث المقابلات والملاحظة والتوثيق. استخدمت تقنيات تحليل البيانات بيانات التجميع وتقليل البيانات والخلاصة والتحقق. خلصت نتائج هذا البحث إلى أن إستراتيجية المعلم في تشكيل الشخصية في المدرسة الابتدائية تتضمن مسابقة التلوين لكل شهر للصف الأول إلى الثالث وعقد مسابقة الطهي والتطريز للصف الرابع حتى الخامس. وتتمثل استراتيجية المعلم في تنفيذ التشكيل الشخصية أن تصافح عند دخول الفصل مع إن جميع المعلمين ، يدرس الطلاب لإعداد معداهم المدرسية ، ويعلم الطلاب لتنظيف الفصل. الاثر لتشكيل

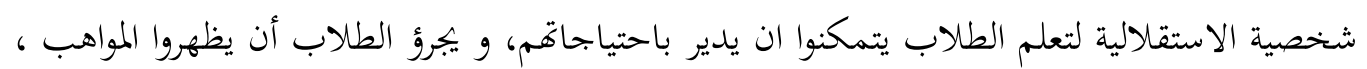
والطلاب أكثر جرأة للقيام بأنشطتهم 


\section{BAB I}

\section{PENDAHULUAN}

\section{A. Konteks Penelitian}

Pembangunan karakter merupakan hal yang penting untuk kehidupan berbangsa dan bernegara. Menurut Kemendiknas pembangunan karakter merupakan upaya perwujudan amanat Pancasila dan pembukaan UUD 1945 dilatar belakangi oleh realita permasalahan kebangsaan yang berkembang saat ini, seperti: disorientasi dan belum dihayatinya nilai-nilai Pancasila, keterbatasan perangkat kebijakan terpadu dalam mewujudkan nilai-nilai Pancasila, bergesernya nilai etika dalam kehidupan berbangsa dan bernegara, memudarnya kesadaran terhadap nilai-nilai budaya bangsa, ancaman disintegrasi bangsa dan melemahnya kemandirian bangsa. ${ }^{1}$

Pendidikan karakter untuk mewujudkan cita-cita pembangunan karakter sebagaimana diamanatkan dalam Pancasila dan Pembukaan UUD 1945 serta mengatasi permasalahan kebangsaan saat ini. Berdasarkan hal itu maka pemerintah menjadikan pembangunan karakter sebagai salah satu program prioritas pembangunan nasional. Pendidikan karakter ditempatkan sebagai landasan untuk mewujudkan visi pembangunan nasional, yaitu mewujudkan masyarakat berakhlak mulia, bermoral, beretika, berbudaya, dan beradab berdasarkan falsafah pancasila. $^{2}$

1 Kemendiknas, Panduan Pelaksanaan Pendidikan Karakter, (Jakarta: Puskurbuk Kemendiknas, 2011), hal. 5.

${ }^{2}$ Kemendiknas, Panduan Pelaksanaan Pendidikan Karakter ..., hal. 6. 
Upaya mewujudkan pendidikan karakter sebagaimana yang diamanatkan dalam rencana pembangunan jangka panjang yang menjelaskan bahwa sesungguhnya tujuan pendidikan nasional yaitu pendidikan nasional berfungsi mengembangkan dan membentuk watak serta peradaban bangsa yang bermartabat dalam rangka mencerdaskan kehidupan bangsa, bertujuan untuk berkembangnya potensi peserta didik agar menjadi manusia yang beriman dan bertakwa kepada Tuhan Yang Maha Esa, berakhlak mulia, sehat, berilmu, cakap, kreatif, mandiri dan menjadi warga negara yang demokratis serta bertanggung jawab. ${ }^{3}$

Karakter menurut cara pandang Islam merupakan bentuk lain dari akhlak yang mencakup pengetahuan dan pengalaman langsung yang membentuk watak dan sifat seseorang yang bersifat melekat dan secara praktis berimbas pada perilaku nyata seseorang yang menjadi kebiasaan. Watak manusia dan perbuatannya merupakan satu kesatuan yang tidak dapat dipisahkan antara satu dengan yang lainnya, dan terdapat jalinan yang sangat erat. Jika watak seseorang dibentuk oleh pengalaman dan pengetahuan buruk, maka perbuatannya juga akan cenderung mengarah ke sana. Demikian sebaliknya jika baik, maka perbuatannya akan baik. Orang yang watak dan perbuatannya terbiasa dengan hal-hal yang baik maka akan tidak nyaman jika diperintahkan untuk melakukan kejahatan, dia akan merasa bersalah, gelisah dan terus diliputi suasana hati yang tidak tenteram. Penyebabnya adalah karena kebiasaan yang sudah terbentuk menjadi wataknya. ${ }^{4}$

Kegagalan dalam belajar bukan karena kecerdasan tetapi karena karakter siswa. Joseph Zins dkk. menjelaskan berbagai hasil penelitian tentang pengaruh

\footnotetext{
Nasional.

${ }^{3}$ Undang-undang Republik Indonesia Nomor 20 Tahun 2003 tentang Sistem Pendidikan

${ }^{4}$ Amin Syukur, Studi akhlak, (Semarang: Wali Songo Press, 2010), hal. 5.
} 
positif kecerdasan emosi siswa terhadap keberhasilan di sekolah. Dikatakan bahwa terdapat beberapa faktor resiko penyebab kegagalan siswa di sekolah. Faktor-faktor resiko yang disebutkan ternyata bukan terletak pada kecerdasan otak tetapi pada karakter yaitu rasa percaya diri, bekerja sama, mandiri, bersosialisasi, berkonsentrasi, rasa empati dan komunikasi. ${ }^{5}$

Banyak faktor yang menyebabkan kepribadian atau karakter siswa memburuk. Hal ini dapat dilihat dari prilaku atau etika siswa dalam belajar; mudah putus asa jika belum bisa, tidak jujur dalam belajar. Kurang dapat menghargai pendapat teman, kurang demokratis, tidak disiplin dalam belajar, tidak mandiri dalam belajar, dan juga kurang kreatif. Pada pembelajaran akhlak misalnya, siswa kurang biasa menunjukkan prilaku yang kontraproduktif dalam persoalan-persoalan akhlak. Mereka membaca tetapi tidak memahami makna dari suatu pertanyaan, tidak mencerna informasi yang diperoleh, tidak yakin dengan cara yang digunakan untuk menyelesaikan soal, dan cepat menyerah ketika tidak tahu bagaimana menyelesaikan soal tersebut. Dari kesehari-harian prilaku atau etika siswa di kelas yang demikian berakibat lunturnya/memburuknya karakter siswa. $^{6}$

Pendidikan karakter bisa dilakukan dengan pembiasaan untuk berperilaku positif dan menjauhi perilaku negatif. The Character Education Partnership menyusun 11 prinsip pendidikan karakter yang efektif ${ }^{7}$ yaitu: (1) mempromosikan nilai-nilai kode etik berdasarkan karakter positif; (2) mendefinisikan karakter

\footnotetext{
${ }^{5}$ Joseph Zins, Roger Weissberg, Margaret Wang dan Herbert Walberg, Building Academic Succes on Social and Emotional Learning, (New York and London: Teachers College Press, 2004).

${ }^{6}$ Rianawati, Internalisasi Karakter Kemandirian Melalui Pembelajaran Konstruktif Di Perguruan Tinggi, (At-Turats, Jurnal Pemikiran Pendidikan Islam, Vo. 8, No. 2, 2014), hal 1.

${ }^{7}$ Endang Mulyatiningsih, Analisis Model-model Pendidikan Karakter Usia Aanak-anak, Remaja dan Dewasa, Jurnal UNY, Volume 4, hal. 4.
} 
secara komprehensip untuk berpikir, berperasaan dan berperilaku; (3) menggunakan pendekatan yang efektif, komprehensif, intensif dan proaktif; (4) menciptakan komunitas sekolah yang penuh kepedulian; (5) menyediakan kesempatan kepada siswa untuk melakukan dan mengembangkan tindakan bermoral; (6) menyusun kurikulum yang menantang dan bermakna untuk membantu agar semua siswa dapat mencapai kesuksesan; (7) membangkitkan motivasi instrinsik siswa untuk belajar dan menjadi orang yang baik di lingkungannya; (8) menganjurkan semua guru sebagai komunitas yang profesional dan bermoral dalam proses pembelajaran; (9) merangsang tumbuhnya kepemimpinan yang transformasional untuk mengembangkan pendidikan karakter sepanjang hayat; (10) melibatkan anggota keluarga dan masyarakat sebagai mitra dalam pendidikan karakter; (11) mengevaluasi karakter warga sekolah untuk memperoleh informasi dan merancang usaha-usaha pendidikan karakter selanjutnya. ${ }^{8}$

Karakter yang dikembangkan menurut Kemendiknas ${ }^{9}$ digolongkan menjadi 18 karakter. Karakter tersebut terdiri dari: Religius, Jujur, Toleransi, Disiplin, Kerja Keras, Kreatif, Mandiri, Demokratis, Rasa Ingin Tahu, Semangat Kebangsaan, Cinta Tanah Air, Menghargai Prestasi, Bersahabat/Komunikatif, Cinta Damai, Gemar Membaca, Peduli Lingkungan, Peduli Sosial, Tanggung Jawab.

${ }^{8}$ Victor Battistich, Character Education, Preventation, and Positive Youth Development of University of Missouri St Louis. (Journal of social Scine, Vol. 01, No. 2, 2010), hal. 3.

${ }^{9}$ Kemendiknas, Penerapan Pendidikan Karakter Bangsa, (Jakarta: Badan Penelitian dan Pengembangan Pusat Kurikulum, 2010), hal. 9. 
Melihat dari 18 karakter yang telah diuraikan, karakter mandiri menjadi salah satu karakter yang cukup penting dan perlu ditanamkan pada siswa. Banyak orang tua maupun guru mengeluh anak atau siswanya kurang mandiri, melaksanakan tugas-tugasnya sendiri. Anita Lie dan Sarah Prasasti ${ }^{10}$ mengemukakan bahwa kemandirian adalah kemampuan untuk melakukan kegiatan atau tugas sehari-hari sendiri atau dengan sedikit bimbingan, sesuai dengan tahap perkembangannya. Bagi anak usia SD, kemandirian merupakan faktor psikologis yang fundamental, sebab sebagai jembatan untuk lepas dari ikatan emosional orang lain. Bagi anak, kemandirian yang kuat akan menjadi dasar bagi kemandirian pada masa remaja, dewasa, dan seterusnya. Bahkan pentingnya kemandirian yang diperoleh anak terkait dengan pencapaian identitas diri kelak pada masa remaja. Oleh karena itu, anak usia SD harus mulai dengan gigih dalam memperjuangkan kemandirian. Mengacu pada pendapat tersebut bahwa siswa yang dapat melakukan kegiatan atau menyelesaikan tugas sendiri dengan sedikit bimbingan mengerucut pada siswa kelas tinggi.

Hasil penelitian mengemukakan adanya kaitan prestasi akademik pada siswa dengan tingginya kemandirian belajar. ${ }^{11}$ Kemandirian belajar siswa diperlukan agar mereka mempunyai tanggung jawab dalam mengatur dan mendisplinkan dirinya. Selain itu, dalam mengembangkan kemampuan belajar dan kemauan sendiri, sikap-sikap tersebut perlu dimiliki oleh siswa sebagai

${ }^{10}$ Anita Lie, Sarah Prasasti, Menjadi Orang Tua Bijak, 101 Cara Membina Kemandirian dan Tanggung Jawab Anak, (Jakarta: Elex Media Komputindo, 2004), hal. 2.

${ }^{11}$ M. Bong, Academic motivation in self-efficacy, task value, achievement goal orientation and attributional beliefs. Journal of Educational Research, 97(6), 2004, hal. 115-125; Lounsbury, J.W., Levy, J. J., Park, S.-H., Gibson, L.W. \& Smith, R., An investigation of the construct validity of the personality trait of self-directed learning. International Journal of Learning and Individual Differences, Vol. 19, No. 4, 2009), hal. 203-256. 
peserta didik karena hal tersebut merupakan ciri dari kedewasaan orang terpelajar. $^{12}$

Siswa dituntut untuk lebih mandiri, sehingga tidak canggung dalam menapaki pendidikan selanjutnya. Kemandirian akan membentuk rasa percaya diri, eksploratif dan kreatif pada diri siswa, sehingga dalam proses pembelajaran akan tercipta kondisi kelas yang hidup dan diharapkan mencapai prestasi yang tinggi pula. ${ }^{13}$ Kemandirian yang seharusnya diterapkan kepada siswa yaitu pada saat proses belajar mengajar seharusnya siswa lebih aktif, tidak tergantung kepada orang lain, dan siswa seharusnya lebih fokus pada saat proses pembelajaran sehingga pada saat guru memberikan tugas siswa tidak terlihat kebingungan dan gugup. ${ }^{14}$ Siswa yang mandiri dalam belajar berarti siswa tersebut memiliki sikap dan prilaku, merasakan sesuatu, bernalar dan mengambil keputusan sesuai dengan kemampuannya sendiri. ${ }^{15}$

Fakta saat ini masih banyak terdapat siswa yang kemandirian belajarnya masih rendah yang ditandai dengan adanya siswa yang tidak tahan lama dalam belajar, malas belajar, dan baru belajar jika menjelang ujian. ${ }^{16}$ Siswa yang memiliki kemandirian belajar rendah memiliki resiko lebih tinggi untuk mengalami kegagalan dalam studinya ketika belajar di lingkungan sekolah yang

${ }^{12}$ Miftaqul Al Fatihah, Hubungan Antara Kemandirian Belajar dengan Prestasi Belajar Pai Siswa Kelas III SDN Panularan Surakarta, (At-Tanbawi, Vol. 1, No. 2, 2016), hal. 197-203.

${ }^{13}$ P. Suparno, Reformasi pendidikan, (Yogyakarta: Kanisius, 2002), hal. 20.

${ }^{14} \mathrm{Ni}$ Md. Sri Jayantini, Made Sulastri, Gede Sedanayasa, Hubungan Pola Asuh Orang Tua terhadap Kemandirian Belajar Siswa Kelas XI SMA Negeri 1 Sukasada Tahun Pelajaran 2013/2014, (E-journal Undiksa Jurusan Bimbingan Konseling, Vol. 2, No 1, 2014), hal. 1-10.

${ }^{15}$ Haerudin, Pembelajaran dengan Pendekatan Savi untuk Meningkatkan Kemampuan Penalaran Matematik dan Kemandirian Belajar Siswa SMP, (Jurnal Pendidikan Unsika, Vol. 3, No. 1, 2015), hal. 23-33.

${ }^{16}$ Jayantini, S., Sulastri, M. dan Sedanayasa, G, Hubungan Pola Asuh Orang Tua terhadap Kemandirian Belajar Siswa Kelas XI SMA Negeri 1 Sukasada, (Jurnal Bimbingan Konseling, Vol. 2, No. 1, 2014), hal. 98-125. 
memiliki kurikulum dan media pembelajaran yang kompleks dan modern. ${ }^{17}$ Malas belajar, cepat menyerah, kurang aktif dalam kegiatan pembelajaran, acuh tak acuh, tidak memperhatikan penjelasan dari dosen atau teman, cepat putus asa menunjukkan lunturnya atau memburuknya karakter atau kepribadian. ${ }^{18}$

Kemandirian belajar sering dikaitkan dengan metode pembiasaan dimana metode pembiasaan merupakan sebuah cara yang dapat dilakukan untuk membiasakan anak didik berfikir, bersikap dan bertindak sesuai dengan aturan yang ada. Pembiasaan merupakan upaya praktis dalam pendidikan dan pembinaan anak. Hasil dari pembiasaan yang dilakukan seorang pendidik adalah terciptanya suatu kebiasaan bagi anak didiknya, dengan diadakannya pembiasaan bisa menciptakan karakter kemandirian belajar siswa yang efektif. Kebiasaan yang buruk juga bisa berakibat dengan karakter siswa tersebut terutama karakter kemandirian belajar siswa.

Rendahnya kemandirian belajar ini tidak hanya dialami siswa normal akan tetapi juga dialami oleh anak berkebutuhan khusus, dimana anak berkebutuhan khusus berbeda dengan anak normal pada umumnya. Menurut Dermawan anak berkebutuhan khusus (ABK) adalah anak yang secara signifikan mengalami kelainan atau penyimpangan (fisik, mental-intelektual, sosial, dan emosional) dalam proses pertumbuh kembangannya dibandingkan dengan anakanak lain yang seusia sehingga memerlukan pelayanan pendidikan khusus. ${ }^{19}$ ABK adalah anak yang dalam pendidikan memerlukan pelayanan yang spesifik,

\footnotetext{
${ }^{17}$ Abar, B. dan Loken, E., Self-regulated Learning and Self-directed Study in A Precollege Sample, (Learning and Individual Differences, Vol. 20, No. 1, 2010), hal. 25-29.

${ }^{18}$ Rianawati, Internalisasi Karakter Kemandirian Melalui Pembelajaran Konstruktif Di Perguruan Tinggi, (At-Turats, Jurnal Pemikiran Pendidikan Islam, Vo. 8, No. 2, 2014), hal. 2.

19 Oki Dermawan, Strategi Pembelajaran bagi Anak Berkebutuhan Khusus di SLB, Psympathic, (Jurnal Ilmiah Psikologi, Vol. 4, No.2, 2013), hal. 886-897.
} 
berbeda dengan anak pada umumnya. ABK mengalami hambatan dalam belajar dan perkembangan, oleh sebab itu mereka memerlukan layanan pendidikan yang sesuai dengan kebutuhan belajar masing-masing anak..$^{20}$

Pasal 32 ayat 1 Undang-Undang No. 20 Tahun 2003 memberikan batasan bahwa pendidikan khusus merupakan pendidikan bagi peserta didik yang memiliki tingkat kesulitan dalam mengikuti proses pembelajaran karena kelainan fisik, emosional, mental, sosial, dan/atau memiliki potensi kecerdasan dan bakat

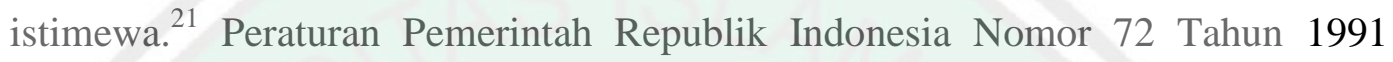
tentang Pendidikan Luar Biasa menyatakan bahwa peserta didik berkebutuhan khusus mempunyai hak: (1) memperoleh perlakuan sesuai dengan bakat, minat, kemampuan, dan kelainannya; (2) memperoleh pendidikan agama sesuai dengan agama yang dianutnya; (3) mengikuti program pendidikan yang bersangkutan atas dasar pendidikan berkelanjutan, baik untuk mengembangkan kemampuan diri maupun untuk memperoleh pengakuan tingkat pendidikan tertentu yang telah dibakukan; (4) memperoleh bantuan fasilitas belajar, beasiswa, atau bantuan lain sesuai dengan kelainan yang disandang dan persyaratan yang berlaku; (5) pindah ke sekolah yang sejajar atau melanjutkan ke tingkat yang lebih tinggi sesuai dengan kelainan yang disandang dan persyaratan penerimaan siswa pada sekolah yang hendak dimasuki; (6) memperoleh penilaian hasil belajar; (7) menyelesaikan program pendidikan lebih awal dari waktu yang ditentukan; dan (8) memperoleh pelayanan khusus sesuai dengan jenis kelainan yang disandang. ${ }^{22}$

${ }^{20}$ Lilik Maftuhatin, Evaluasi Pembelajaran Anak Berkebutuhan Khusus (ABK) di Kelas Inklusif di SD Plus Darul 'Ulum Jombang, (Religi: Jurnal Studi Islam, Vol. 5, No. 2, 2014), hal. 201-227.

${ }^{21}$ Undang-Undang Nomor 20 tahun 2003 tentang Sistem Pendidikan Nasional Indonesia. Luar Biasa.

${ }^{22}$ Peraturan Pemerintah Republik Indonesia Nomor 72 Tahun 1991 tentang Pendidikan 
Dari uraian di atas dijelaskan bahwa tentang pendidikan anak berkebutuhan khusus (ABK) mempunyai hak yang sama dengan anak normal pada umumnya, begitu juga dalam pencapaian hasil belajar. Hasil belajar siswa juga dipengaruhi oleh kemandirian belajar siswanya. Dalam hal ini menurut Mashur, Rena Lestari dan Dahlia kemandirian belajar memiliki indikator yaitu mengatur waktu Belajar, mengulang materi pelajaran di rumah, mengerjakan tugas, konsentrasi dan fasilitas belajar. ${ }^{23}$ Sedangkan untuk indikator kemandirian belajar pada anak berkebutuhan khusus diantaranya yaitu bertanggung jawab atas tugasnya, percaya diri dalam melakukan suatu hal, menyesuaikan diri dengan lingkungan, mengembangkan diri untuk berkembang. ${ }^{24}$

Anak berkebutuhan khusus mempunyai variasi dan kelainan, ini mencakup anak-anak yang mengalami kelainan fisik, mental intelektual, sosial emosional, maupun masalah akademik dan anak autis. Anak-anak berkelainan fisik meliputi anak tuna netra (ganngguan fungsi penglihatan), anak tuna rungu(gangguan fungsi pendengaran), anak tuna daksa (gangguan cacat tubuh). Anak yang mengalami kelainan sosial emosional yaitu anak tuna grahita (gangguan fungsi kecerdasan), anak tuna laras (gangguan prilaku). Anak yang mengalami kelainan akademik yaitu anak berbakat (IQ tinggi) dan anak yang mengalami kesulitan belajar. ${ }^{25}$

Pembelajaran pada ABK membutuhkan suatu strategi tersendiri sesuai dengan kebutuhan masing-masing siswa. Menurut Agustin dan Pandi pada anak

\footnotetext{
${ }^{23}$ Mashur, Rena Lestari dan Dahlia, Analisis Kemandirian Belajar Siswa Kelas Vii Pada Mata Pelajaran Ipa Terpadu Di Smp Negeri 1 Rambah Samo Kabupten Rokan Hulu Tahun Pembelajaran 2014/2015, (E-jurnal Mahasiswa Prodi Biologi, Vo. 1, No. 1, 2015), hal. 1-3. hal. 130.

${ }^{24}$ Syamsu Yusuf, Psikologi Perkembangan Anak, (Bandung: Remaja Rosdakarya, 2008),

25 Muhamad Afandi dan Galuh, Pendidikan Anak Berkebutuhan Khusus, (Semarang: Unisulla Press, 2013), hal. 7.
} 
ABK mereka memiliki keterbatasan. Guru dituntut untuk berperan lebih banyak dalam mengoptimalkan cognitive process ABK. Oleh karena itu, peran guru amatlah penting. ${ }^{26}$

ABK dididik dalam sistem pendidikan di sekolah luar biasa (SLB). Menurut Suparno merupakan pendidikan bagi peserta didik yang memiliki tingkat kesulitan dalam mengikuti proses pembelajaran karena kelainan fisik, emosional, mental sosial, tetapi memiliki potensi kecerdasan dan bakat istimewa. ${ }^{27}$ SLB adalah sebuah lembaga pendidikan formal yang melayani pendidikan bagi anakanak berkebutuhan khusus. Sebagai lembaga pendidikan SLB dibentuk oleh banyak unsur yang diarahkan untuk mencapai tujuan pendidikan yang mana proses intinya adalah pembelajaran bagi peserta didik. Jadi SLB merupakan lembaga pendidikan khusus yang menyelenggarakan program pendidikan bagi $\mathrm{ABK}^{28}$

Salah satu SDLB di Kabupaten Tulungagung adalah SDLB Negeri Tulungagung. SDLB ini berlokasi di Jl.P Diponegoro V /2 Tulungagung, Kelurahan Tamanan, Kecamatan Tulungagung, Kabupaten Tulungagung, Provinsi Jawa Timur. SDLB Negeri Tulungagung memiliki guru yang berjumlah 9, penyelenggaraan pendidikan terdiri dari 6 rombongan dengan siswa berjumalah 34. SDLB ini khusus SDLB bagian B atau tuna rungu, dimana tuna rungu adalah individu yang mengalami gangguan dalam indera pendengaran, individu ini memiliki hambatan dalam berbicara sehingga mereka biasa disebut tunawicara.

\footnotetext{
${ }^{26}$ Leonita Dwi Agustin dan Weny Savitry S. Pandi, Pemahaman Pedagogik Guru dalam Mengajar Anak Berkebutuhan Khusus di Sekolah Inklusi, (Provitae Jurnal Psikologi Pendidikan, Vol. 6, No. 1, 2014), hal. 73-98. 2007), hal. 97.

27 Suparno, Pendidikan Anak Berkebutuhan Khusus, (Jakarta: Dirjen Dikti Depdiknas,

${ }^{28}$ I Nyoman Bayu Pramartha, Sejarah dan Sistem Pendidikan Sekolah Luar Biasa bagian a Negeri Denpasar Bali, (Jurnal Historia, Vol. 3, No. 2, 2015), 67-74.
} 
Metode pengajaran bagi anak tuna rungu menggunakan tiga metode yaitu dengan membaca ujaran, ujarannya melalui gerakan bibirnya. Metode ke dua yaitu melalui metode dengar, individu tuna rungu dapat memperoleh manfaat dari alat bantu dengar. Metode terkhir yang digunakan adalah metode pembelajaran secara manual yaitu dengan menggunakan bahasa isyarat, untuk tujuan universal berbagai Negara telah mengembangkan bahasa isyarat yang dibakukan secara nasional, komunikasi manual dengan bahasa isyarat yang baku memberikan gambaran lengkap tentang bahasa kepada tunarungu.

Pada SDLB B ini menggunakan kurikulum K13 dengan bobot yang berbeda dan disesuaikan dengan kebutuhannya, RPP yang digunakan di SDLB sama dengan RPP yang ada disekolah regular namun tetap disesuaikan dengan kondisi kelas, dimana ada tiga kriteria yang dimiliki oleh anak yaitu total, sedang dan ringan. Keberhasilan yang dicapai oleh setiap anak pun berbeda, ada yang bisa menangkap dalam waktu sehari, seminggu, sebulan bahkan tahunan tergantung kemampuan anak tersebut dalam menangkap materi pembelajaran.

Penelitian ini difokuskan pada siswa SDLB bagian B yaitu tunarungu kelas 1 dan 4, kelas 1 dijadikan sample pada penelitian ini dikarenakan sebagai pengamatan untuk kelas rendah, sedangkan kelas 4 sebagai pengamatan untuk kelas tinggi. Sedangkan guru sebagai informan utama dalam penelitian.

Hasil penelitian terdahulu tentang ABK dilakukan oleh Supardjo tahun 2016 tentang pengelolaan pembelajaran anak berkebutuhan khusus di Sekolah Dasar penyelenggaran pendidikan inklusif Sekolah Dasar Negeri III Giriwono Wonogiri. Dalam penelitiannya menjelaskan tentang pengelolaan pembelajaran untuk ABK di sekolah inklusi yang mana hasilnya dari segi perencanaan, 
pelaksanaan dan evaluasi sudah sesuai dengan kurikulum yang ada, namun masih menemui kendala, dalam pembelajaran anak ABK masih kesulitan dalam menerima pembelajaran karena bercampur dengan anak normal. ${ }^{29}$ Hasil penelitian Fida Rahmantika Hadi tahun 2014 tentang analisis proses pembelajaran matematika pada anak berkebutuhan khusus ( $\mathrm{ABK}$ ) slow learners di kelas inklusi (penelitian dilakukan di SD Al Firdaus Surakarta). Hasil penelitiannya menunjukkan adanya kendala yang dialami ABK yaitu kesulitan dalam menanamkan konsep matematika. ${ }^{30}$ Hasil penelitian Muhdar Mahmud tahun 2003 tentang layanan bimbingan bagi anak berkebutuhan khusus di Sekolah Dasar Wilayah Kota Bandung. Penelitian ini menunjukkan bahwa pada layanan bimbingan bagi anak berkebutuhan khusus sangatlah penting, kendalanya masih banyak sekolah ABK yang belum menggunakan layanan bimbingan ini. ${ }^{31}$ Hasil penelitian Evi Marlinda tahun 2011 tentang pengalaman ibu dalam merawat anak dengan keutuhan khusus: autis di Banjarbaru Kalimantan Selatan. Hasil penelitiannya membuktikan bahwa anak yang berkebutuhan khusus lebih ekstra dalam perawatannya, yang mana anak tersebut tidak bisa diperlakukan keras. ${ }^{32}$

Persamaan penelitian ini dengan penelitian di atas terletak pada penjelasan tentang pembelajaran pada ABK dan penanganan pada ABK. Perbedaan penelitian ini dengan penelitian di atas yaitu penelitian ini lebih menekankan pada strategi pembelajaran dalam membentuk karakter pada ABK di SLB, yang mana

${ }^{29}$ Supardjo, Pengelolaan Pembelajaran Anak Berkebutuhan Khusus Di Sekolah Dasar Penyelenggaran Pendidikan Inklusif Sekolah Dasar Negeri III Giriwono Wonogiri, (Tesis, Pascasarjana, Universitas Muhammadiyah Surakarta, 2016).

30 Fida Rahmantika Hadi, Analisis Proses Pembelajaran Matematika pada Anak Berkebutuhan Khusus (ABK) Slow Learners di Kelas Inklusi (Penelitian Dilakukan di SD Al Firdaus Surakarta), (Tesis, Pascasarjana, Universitas Sebelas Maret Surakarta, 2014).

${ }^{31}$ Muhdar Mahmud, Layanan Bimbingan bagi Anak Berkebutuhan Khusus di Sekolah Dasar Wilayah Kota Bandung, (Tesis, Pascasarjana, Universitas Pendidikan Indonesia, 2003).

${ }^{32}$ Evi Marlinda, Pengalaman Ibu dalam Merawat Anak dengan Keutuhan Khusus: Autis di Banjarbaru Kalimantan Selatan, (Tesis, Pascasarjana, Universitas Indonesia, 2011). 
dengan adanya penelitian karakter kemandirian belajar pada ABK bisa memudahkan siswa ABK dalam mendapatkan pembelajaran. Orisinalitas pada penelitian ini yaitu strategi pembelajaran untuk membentuk karakter kemandirian belajar pada ABK di SDLB.

Berdasarkan pentingnya program pendidikan dalam membentuk kemandirian belajar siswa ABK maka guru pendidikan luar biasa mempunyai tanggung jawab besar dalam membentuk karakter ABK. Oleh karena itu diperlukan sebuah penelitian tentang strategi guru dalam membentuk karakter kemandirian belajar siswa berkebutuhan khusus melalui metode pembiasaan di SDLB Tunarungu Negeri Tulungagung.

\section{B. Fokus Penelitian}

1. Bagaimana strategi guru dalam pembentukan karakter kemandirian belajar pada siswa berkebutuhan khusus melalui metode pembiasaan di SDLB Tunarungu Negeri Tulungagung?

2. Bagaimana pelaksanaan strategi guru dalam pembentukan karakter kemandirian belajar pada siswa berkebutuhan khusus melalui metode pembiasaan di SDLB Tunarungu Negeri Tulungagung?

3. Apa dampak dalam pembentukan karakter kemandirian belajar pada siswa berkebutuhan khusus melalui metode pembiasaan di SDLB Tunarungu Negeri Tulungagung? 


\section{Tujuan Penelitian}

1. Mengungkap strategi guru dalam pembentukan karakter kemandirian belajar pada siswa berkebutuhan khusus melalui metode pembiasaan di SDLB Tunarungu Negeri Tulungagung.

2. Mengungkap pelaksanaan strategi guru dalam pembentukan karakter kemandirian belajar pada siswa berkebutuhan khusus melalui metode pembiasaan di SDLB Tunarungu Negeri Tulungagung.

3. Mengungkap dampak dalam pembentukan karakter kemandirian belajar pada pada siswa berkebutuhan khusus melalui metode pembiasaan di SDLB Tunarungu Negeri Tulungagung.

\section{Manfaat Penelitian}

Manfaat penelitian ini terdiri dari manfaat teoritis dan manfaat praktis. Manfaat penelitian dijelaskan sebagai berikut.

1. Manfaat Teoritis

Penelitian ini memberikan sumbangan keilmuan tentang strategi pembelajaran dalam membentuk karakter siswa ABK. Penelitian ini mempertegas terminologi tentang strategi guru.

2. Manfaat Praktis

Manfaat praktis penelitian ini dijelaskan sebagai berikut.

a) Manfaat untuk Guru

Penelitian ini memberikan masukan bagi guru bahwa strategi pembelajaran yang tepat dapat membentuk karakter kemandirian belajar pada siswa $\mathrm{ABK}$. 
b) Manfaat untuk Kepala Madrasah

Penelitian ini sebagai masukan dalam pengambilan kebijakan kepala sekolah dalam penyelenggaraan pembelajaran untuk ABK.

\section{E. Definisi Istilah}

Definisi operasional yang digunakan dalam penelitian ini dijelaskan sebagai berikut.

1. Strategi guru

Strategi adalah garis besar haluan bertindak untuk mencapai sasaran yang telah ditentukan. Strategi juga diartikan sebagai perencanaan yang berisi tentang serangkaian kegiatan yang didesain untuk mencapai tujuan pendidikan tertentu. ${ }^{33}$ Jadi strategi guru adalah suatu upaya yang dilakukan guru dalam mengelola kelas untuk memberikan rasa kondusif pada anak dalam rangka mencapai tujuan pendidikan.

2. Pendidikan karakter

Pendidikan karakter sebagai pendidikan yang menanamkan dan mengembangkan karakter-karakter luhur kepada anak didik sehingga mereka memiliki karakter luhur, menerapkan dan mempraktikkan dalam kehidupannya, sebagai keluarga, anggota masyarakat dan warga negara. ${ }^{34}$ Pendidikan karakter sebagai pedoman bagi siswa dalam bersikap dan bertindak. Keberhasilan siswa terletak pada bagaimana karakter siswa tersebut.

${ }^{33}$ Hamdani, Strategi Belajar Mengajar, (Bandung: Pustaka Setia, 2011), hal. 18.

34 Syamsul Kurniawan, Pendidikan Karakter: Konsepsi \& Implementasinya secara Terpadu di Lingkungan Keluarga, Sekolah, Perguruan Tinggi, dan Masyarakat, (Yogyakarta: ArRuzz Media, 2014), hal. 31. 


\section{Kemandirian belajar}

Kemandirian belajar adalah sebuah proses di mana individu mengambil inisiatif tanpa bantuan orang lain dalam memenuhi kebutuhan belajar. ${ }^{35}$ Jadi kemandirian belajar merupakan suatu perubahan dalam diri seseorang untuk melakukan aktivitas belajar dengan cara mandiri atas dasar motivasinya sendiri.

4. Sekolah Luar Biasa

Sekolah luar biasa adalah bentuk layanan pendidikan bagi anak berkebutuhan khusus.

5. Anak berkebutuhan khusus

Anak berkebutuhan khusus adalah anak yang memiliki kelainan dalam fisik, mental maupun karakteristik perilaku sosialnya yang berbeda dari ratarata umumnya ${ }^{36}$. ABK memiliki klasifikasi tertentu diantaranya anak tuna netra (gangguan penglihatan), tuna netra (gangguan pendengaran), tuna daksa (gangguan cacat fisik).

6. Metode pembiasaan

Metode pembiasaan yaitu sebuah metode dalam pendidikan berupa proses penanaman kebiasaan Inti dari pembiasaan ialah pengulangan. Jika guru setiap masuk kelas mengucapkan salam, itu telah dapat diartikan sebagai usaha membiasakan, pembiasaan dapat diartikan sebagai sebuah cara yang

${ }^{35}$ Wuri Wuryandani, Implementasi Karakter Kemandirian di Muhammadiyah Boarding School, Jurnal cakrawala Pendidikan, Juni 2016, Th 35, No. 2, hal. 210.

${ }^{36}$ Abdurrahman Mulyono, Pendidikan Bagi Anak Berkesulitan belajar, (Jakarta: Rineka Cipta, 2010), hal. 25. 
dapat dilakukan untuk membiasakan anak didik berfikir, bersikap dan bertindak sesuai dengan aturan yang ada.

\section{F. Sistematika Pembahasan}

Untuk memudahkan arah yang tepat, perumusan sistematika pembahasan di susun sebagai berikut:

Bab pertama berisi tentang pendahuluan, yang terdiri dari konteks penelitian, fokus penelitian, tujuan penelitian, manfaat penelitian, definisi istilah, dan sistematika pembahasan.

Bab kedua berisi tentang kajian pustaka di dalamnya membahas pendidikan karakter yang meliputi pengertian pendidikan karakter, tujuan pendidikan karakter, fungsi pendidikan karakter, jenis-jenis pendidikan karakter, tahapan dalam pendidikan karakter, selanjutnya membahas tentang kemandirian belajar yang meliputi pengertian kemandirian belajar, fungsi kemandirian belajar, faktor-faktor yang mempengaruhi kemandirian belajar, indikator kemandirian belajar, langkah-langkah menciptakan kemandirian belajar, pendidikan karakter kemandirian di sekolah, selanjutnya membahas tentang dampak pelaksanaan pendidikan karakter, selanjutnya ada pengertian anak berkebutuhan khusus, jenisjenis anak berkebutuhan khusus, dan penyebab anak berkebutuhan khusus, kemudian dalam bab dua ini juga membahas tentang pengertian metode pembiasaan, landasan metode pembiasaan, tujuan metode pembiasaan, bentukbentuk metode pembiasaan, dan kelebihan dan kekurangan metode pembiasaan, selanjutnya membahas tentang strategi guru dalam membentuk karakter kemandirian belajar siswa, yang terakhir membahas tentang kerangka pikir penelitian. 
Bab ketiga membahas tentang metodologi penelitian yang berisi pendekatan dan jenis penelitian, kehadiran peneliti, lokasi penelitian, sumber data yang ada, teknik pengumpulan data yang meliputi wawancara, observasi, dan dokumentasi, selanjutnya membahas tentang analisis data yang meliputi pengelompokan data, reduksi data dan penarikan kesimpulan, selanjutnya uji keabsahan data yang meliputi triangulasi, dan member cheking, yang terakhir prosedur penelitian.

Bab keempat membahas paparan data dan hasil penelitian yang meliputi gambaran umum lokasi sekolah dasar, visi misi dan tujuan sekolah, jumlah guru dan tenaga administrasi, jumlah peserta didik dan jumlah kelas, sarana dan prasarana, yang terakhir membahas tentang hasil penelitian strategi guru dalam membentuk karakter kemandirian belajar siswa berkebutuhan khusus melalui metode pembiasaan di sekolah dasar luar biasa tunarungu di Tulungagung, strategi guru dalam pelaksanaan pembentukan karakter kemandirian belajar siswa berkebutuhan khusus melalui metode pembiasaan di sekolah dasar luar biasa tunarungu di Tulungagung, dampak dalam pembentukan karakter kemandirian belajar siswa berkebutuhan khusus melalui metode pembiasaan di sekolah dasar luar biasa tunarungu di Tulungagung.

Bab kelima berisi tentang pembahasan yang terdiri dari strategi guru dalam membentuk karakter kemandirian belajar siswa berkebutuhan khusus melalui metode pembiasaan di sekolah dasar luar biasa tunarungu di Tulungagung, strategi guru dalam pelaksanaan pembentukan karakter kemandirian belajar siswa berkebutuhan khusus melalui metode pembiasaan di sekolah dasar luar biasa Tunarungu di Tulungagung, dampak pembentukan karakter kemandirian belajar 
siswa berkebutuhan khusus melalui metode pembiasaan di sekolah dasar luar biasa tunarungu di Tulungagung.

Bab keenam berisi tentang penutup yang meliputi kesimpulan dari strategi guru dalam membentuk karakter kemandirian belajar siswa berkebutuhan khusus melalui metode pembiasaan di sekolah dasar luar biasa tunarungu di Tulungagung, strategi guru dalam pelaksanaan pembentukan karakter kemandirian belajar siswa berkebutuhan khusus melalui metode pembiasaan di sekolah dasar luar biasa tunarungu di Tulungagung, dampak pembentukan karakter kemandirian belajar siswa berkebutuhan khusus melalui metode pembiasaan di sekolah dasar luar biasa tunarungu di Tulungagung, selanjutnya membahas implikasi dan saran. 


\section{BAB II}

\section{KAJIAN PUSTAKA}

\section{A. Pendidikan Karakter}

\section{Pengertian Pendidikan Karakter}

Secara etimologis kata karakter berasal dari bahasa inggris character, dalam bahasa Yunani charassein yang berarti to engrave. Kata to engrave diterjemahkan mengukir, melukis, atau menggoreskan. Karakter dalam KBBI diartikan sebagai tabiat, watak, sifat-sifat kejiwaan, akhlak atau budi pekerti yang membedakan seseorang dengan yang lain. ${ }^{37}$ Karakter adalah watak, tabiat, akhlak, atau kepribadian seseorang yang terbentuk dari hasil internalisasi berbagai kebajikan yang diyakininya dan digunakannya sebagai landasan untuk cara pandang, berpikir, bersikap dan bertindak. $^{38}$ Pendidikan karakter adalah upaya pendidik untuk menanamkan nilai-nilai karakter kepada peserta didik yang bertujuan mengembangkan kemampuan peserta didik untuk memberikan keputusan baik-buruk, memelihara apa yang baik dan mewujudkannya dalam kehidupan sehari-hari dengan sepenuh hati. ${ }^{39}$ Pendidikan karakter dimaknai sebagai suatu sistem penanaman nilai-nilai karakter kepada warga sekolah yang meliputi komponen pengetahuan, kesadaran atau kemauan, dan tindakan untuk melaksanakan nilai-nilai tersebut, baik

\footnotetext{
${ }^{37}$ John M. Echlos dan Hasan Shadily, An English-Indonesian Dictionary, (Jakarta: PT. Gramedia Pustaka Utama, 2003), hal. 214.

38 Agus Salim Mansyur, Pengembangan Kurikulum Berbasis Karakter: Konsepsi dan Implmentasinya, (Jurnal Pendidikan Universitas Garut, Vol. 01, No. 01, 2007), hal. 1.

39 Kemendiknas, Panduan Pelaksanaan Pendidikan Karakter, (Jakarta: Pusbukur Kemendiknas, 2011), hal. 5.
} 
terhadap Tuhan, diri sendiri, sesama, lingkungan, maupun kebangsaan sehingga menjadi manusia insan kamil (manusia paripurna). ${ }^{40}$ Berdasarkan pendapat tersebut dapat disimpulkan bahwa pendidikan karakter adalah watak, tabiat, akhlak, atau kepribadian yang ditanamkan melalui pengetahuan, kesadaran atau kemauan dan tindakan dalam pendidikan sehingga merubah cara pandang, berpikir, bersikap dan bertindak siswa.

\section{Tujuan Pendidikan Karakter}

Tujuan pendidikan untuk mengembangkan nilai-nilai yang membentuk karakter, meliputi a) mengembangkan potensi peserta didik agar menjadi manusia berhati baik, berpikiran baik, dan berprilaku baik, b) membangun bangsa yang berkarakter, c) mengembangkan sikap percaya diri, bangga pada bangsa dan negaranya serta mencintai umat manusia. ${ }^{41}$

Menurut Nurul Zuriah ujuan pendidikan karakter adalah sebagai berikut: $^{42}$ a) siswa memahami nilai-nilai karakter di lingkungan keluarga, lokal, nasional dan internasional melalui adat istiadat, hukum, undangundang, dan tatanan antarbangsa, b) siswa mampu mengembangkan watak atau tabiatnya secara konsisten dalam mengambil keputuan budi pekerti ditengah-tengah rumitnya kehidupan bermasyarakat saat ini, c) siswa mampu menghadapi masalah nyata dalam masyarakat secara rasional bagi pengambilan keputusan yang terbaik setelah melakukan pertimbangan sesuai dengan norma budi pekerti/karakter, d) siswa mampu menggunakan

\footnotetext{
${ }^{40}$ Agus Salim Mansyur, Pengembangan Kurikulum Berbasis Karakter: Konsepsi dan Implmentasinya ..., hal. 1.

41 Kemendiknas, Panduan Pelaksanaan Pendidikan Karakter, (Jakarta: Pusbukur Kemendiknas, 2011), hal. 7.

${ }^{42}$ Nurul Zuriah, Pendidikan Moral dan Budi Pekerti dalam Prospek Perubahan, (Jakarta: Bumi Aksara, 2007), hal. 38.
} 
pengalaman karakter/budi pekerti yang baik bagi pembentukan kesadaran dan pola perilaku yang berguna dan bertanggunga jawab atas tindakannya.

\section{Fungsi Pendidikan Karakter}

Menurut Kementerian Pendidikan Nasional fungsi pendidikan karakter yaitu: ${ }^{43}$

a. Pengembangan potensi peserta didik untuk menjadi pribadi berperilaku baik; ini bagi peserta didik yang telah memiliki sikap dan perilaku yang mencerminkan budaya dan karakter bangsa.

b. Perbaikan : memperkuat kiprah pendidikan nasional untuk bertanggung jawab dalam pengembangan potensi peserta didik yang lebih bermartabat.

c. Penyaring: untuk menyaring budaya bangsa sendiri dan budaya bangsa lain yang tidak sesuai dengan nilai-nilai budaya dan karakter bangsa yang bermartabat.

\section{Jenis-Jenis Pendidikan Karakter}

Ada empat jenis karakter yang selama ini dikenal dan dilaksanakan dalam proses pendidikan, yaitu: ${ }^{44}$

a. Pendidikan karakter berbasis nilai religius, yang merupakan kebenaran wahyu tuhan (konservasi moral).

b. Pendidikan karakter berbasis nilai budaya, antara lain yang berupa budi pekerti, pancasila, apresiasi sastra, keteladanan tokoh-tokoh sejarah dan para pemimpin bangsa.

c. Pendidikan karakter berbasis lingkungan (konservasi lingkungan).

\footnotetext{
${ }^{43}$ Kemendiknas, Panduan Pelaksanaan Pendidikan Karakter ..., hal. 6.

44 Yahya Khan, Pendidikan Karakter Berbasis Potensi Diri, (Yogyakarta: Pelangi Publishing, 2010), hal. 54.
} 
d. Pendidikan karakter berbasis potensi diri, yaitu sikap pribadi, hasil proses kesadaran pemberdayaan potensi diri yang diarahkan untuk meningkatkan kualitas pendidikan (konservasi humanis).

\section{Tahapan dalam Pendidikan Karakter}

Tiga tahapan dalam pendidikan karakter yaitu: ${ }^{45}$

a. Moral Knowing

Tahap ini adalah langka pertama dalam pendidika karakter. Dalam tahap ini diorientasikan pada penguasaan pengetahuan tentang nilainilai moral, kesadaran moral, penentuan sudut pandang, logika moral, pengenalan diri dan keberanian menentukan sikap. Penguasaan terhadap enam unsur ini menjadikan peserta didik mampu membedakan nilainilai akhlak mulia dan akhlak tercela serta nilai universal, dan memahami akhlak mulia secara logis dan rasional bukan secara doktrin.

b. Moral Loving

Merupakan penguat aspek emosi manusia untuk menjadi manusia berkarakter. Penguatan ini berkaitan dengan bentuk sikap yang harus dirasakan oleh siswa, yaitu percaya diri, empaty, cinta kebenaran, pengendalian diri dan kerendahan hati. Tahapan ini dimaksudkan untuk menumbuhkan rasa cinta dan rasa butuh terhadap nilai-nilai akhlak mulia. Jadi, yang menjadi sasaran guru adalah dimensi emosi, hati, dan jiwa bukan kognitif, logika atau akal.

\footnotetext{
${ }^{45}$ Abdul Madjid, Pendidikan Karakter Perspektif Islam, (Bandung: Rosdakarya, 2011),
} hal. 113 . 


\section{c. Moral Doing/Acting}

Merupakan outcome dan puncak keberhasilan peserta didik dalam pendidikan karakter. Wujud dari tahapan ketiga ini adalah mempraktikkan nilai-nilai akhlak dalam perilaku sehari-hari.

\section{B. Kemandirian Belajar}

\section{Pengertian Kemandirian Belajar}

Kemandirian belajar menurut Knowles adalah sebuah proses di mana individu mengambil inisiatif tanpa bantuan orang lain dalam memenuhi kebutuhan belajar, merumuskan tujuan belajar, mengidentifikasi sumber daya materi-materi belajar, memilih dan menerapkan strategi pembelajaran yang tepat serta mengevaluasi hasil pembelajaran. Proses kemandirian belajar meliputi kebutuhan belajar, motivasi belajar, sumber belajar, tujuan pembelajaran, rencana dan kegiatan pembelajaran, evaluasi belajar dan keterampilan komunikasi. ${ }^{46}$ Pendidikan karakter adalah upaya mendorong peserta didik tumbuh dan berkembang dengan kompetensi berpikir dan berpegang teguh pada prinsip-prinsip moral dalam hidupnya serta mempunyai keberanian untuk melakukan yang benar meskipun dihadapkan pada berbagai tantangan. ${ }^{47}$ Tirtahardja mengatakan bahwa kemandirian dalam belajar adalah aktivitas belajar yang berlangsung lebih didorong oleh kemauan sendiri, pilihan sendiri dan tanggung jawab sendiri dari pembelajaran. ${ }^{48}$ Mudjiman

\footnotetext{
${ }^{46}$ Knowles dalam Su-fen cheng, dkk., Development and Preliminary Testing of A selfrating Instrument to Measure Self-directed Learning Ability of Nursing Students, (International Journal of Nursing Studies, Vol. 47, No. 9, 2010), hal. 1152-1158.

47 Zubaidi, Desain Pendidikan Karakter Konsepsi dan Aplikasinya dalam Lembaga Pendidikan, (Jakarta: Pt. Rajagrafindo, 2010), hal. 25.

${ }^{48}$ Tirtahardja, Pengantar Pendidikan, (Jakarta: Rineka Cipta, 2005), hal. 50.
} 
mendefinisikan kemandirian dalam belajar adalah motif atau niat untuk menguasai sesuatu kompetensi adalah kekuatan pendorong kegiatan belajar secara intensif, terarah dan kreatif. ${ }^{49}$ Berdasarkan pendapat tersebut disimpulkan bahwa kemandirian belajar adalah suatu proses pengambilan inisiatif sendiri dalam memenuhi kebutuhan belajar.

\section{Fungsi Kemandirian Belajar}

Kemandirian belajar berfungsi meningkatkan hasil belajr. Menurut Egok kemandirian belajar siswa menuntut untuk aktif baik sebelum dan sesudah proses pembelajaran berlangsung. Siswa yang mandiri akan mempersiapkan materi yang akan dipelajari. Sesudah proses pembelajaran selesai, siswa akan belajar kembali mengenai materi yang sudah disampaikan dengan cara membaca atau berdiskusi. Sehingga siswa yang menerapkan belajar mandiri akan mendapat prestasi lebih baik jika dibandingkan dengan siswa yang tidak menerapkan prinsip mandiri. ${ }^{50}$

\section{Faktor-faktor yang Mempengaruhi Kemandirian Belajar}

Karakter dalam pandangan Lickona karakter mengacu kepada serangkaian pengetahuan (cognitives), sikap (attitudes), motivasi (motivations), perilaku (behaviors) dan keterampilan (skills). ${ }^{51}$

\footnotetext{
${ }^{49}$ Haris Mudjiman, Belajar Mandiri, (Surakarta: UNS Press, 2011), hal. 4.

${ }^{50}$ Asep Sukenda Egok, Kemampuan Berpikir Kritis dan Kemandirian Belajar dengan Hasil Belajar Matematika, (Jurnal Pendidikan Dasar, Vol. 7, No. 2, 2016), hal. 185-198.

51 T. Lickona, Education for Character: How Our Schools can Teach Respect and Responsibility, (New York: Bantam Books, 1991), hal. 51.
} 
Menurut Hasan Basri menjelaskan bahwa kemandirian belajar dipengaruhi oleh faktor internal dan faktor eksternal. ${ }^{52}$

a. Faktor Endogen (Internal)

Semua pengaruh yang bersumber dari dalam dirinya sendiri, seperti keadaan keturunan dan konstitusi tubuhnya sejak dilahirkan, kematangan usia dan jenis kelamin.

b. Faktor eksogen (eksternal)

Pengaruh dari luar seperti kebudayaan, masyarakat yang maju dan kompleks tuntutan kehidupannya cenderung mendorong tumbuhnya kemandirian disbanding dengan masyarakat yang sederhana. Keluarga, meliputi aktifitas pendidikan dalam keluarga, kecenderungan cara mendidik anak, cara memberikan penilaian kepada anak, bahkan sampai cara hidup orangtua berpengaruh terhadap kemandirian anak.

Muhammad Ali dan Muhammad Asrori menyebutkan sejumlah faktor yang mempengaruhi perkembangan kemandirian, yaitu: ${ }^{53}$

a. Gen atau keturunan orang tua

Orang tua memiliki sifat kemandirian tinggi seringkali menurunkan anak yang memiliki kemandirian juga.

b. Pola asuh orang tua

Cara orang tua mengasuh dan mendidik anak akan mempengaruhi perkembangan kemandirian anak remajanya.

${ }^{52}$ Hasan Bahri, Remaja Berkualitas (Problema Remaja dan Solusinya), (Yogyakarta: Pustaka Pelajar, 2000), hal. 54.

${ }_{53}$ Chabib Thoha, Kapita Selekta Pendidikan Islam, (Yogyakarta: Pustaka Pelajar IKAPI, 1996), hal.124. 
c. Sistem pendidikan di sekolah

Proses pendidikan di sekolah yang tidak mengembangkan demokrasi pendidikan dan cenderung menekankan indoktrinasi tanpa argumentasi akan menghambat perkembangan kemandirian remaja sebagai siswa.

d. Sistem kehidupan di masyarakat

Sistem kehidupan masyarakat yang terlalu menekankan pentingnya hirarki struktur sosial, merasa kurang aman.

\section{Indikator Kemandirian Belajar}

Terdapat beberapa indikator kemandirian belajar pada anak Menurut Chabib Thoha membagi ciri kemandirian belajar pada dalam delapan jenis yaitu: ${ }^{54}$

a. Mampu berpikir secara kritis, kreatif dan inovatif.

b. Tidak mudah terpengaruh oleh pendapat orang lain.

c. Tidak lari atau menghindari masalah.

d. Memecahkan masalah dengan berpikir mendalam.

e. Apabila menjumpai masalah dipecahkan sendiri tanpa meminta

f. Berusaha bekerja dengan penuh ketekunan dan kedisiplinan.

g. Bertanggung jawab atas tindakannya sendiri.

Negoro menyatakan bahwa ciri-ciri kemandirian belajar adalah memiliki kebebasan untuk berinisiatif, memilki rasa percaya diri, mampu

\footnotetext{
${ }^{54}$ Chabib Thoha, Kapita Selekta Pendidikan Islam ..., hal.123.
} 
mengambil keputusan, dapat bertanggung jawab, dan mampu menyesuaikan diri dengan lingkungan. ${ }^{55}$

Menurut SC Munandar kemandirian belajar pada ABK dapat diketahui dari $:^{56}$

a. Kemandirian anak dalam menyiapkan alat-alat sekolah.

b. Kemandirian anak dalam mengerjakan pekerjaan rumah.

c. Kemandirian dalam memanfaatkan waktu.

d. Bisa beradaptasi dengan lingkungan.

e. Bertanggung jawab dengan tugasnya.

Sedangkan dalam bukunya Muhamad Afandi tentang Pendidikan Anak Berkebutuhan Khusus indikator kemandirian belajar pada ABK yaitu: ${ }^{57}$

a. Bertanggung jawab atas tugasnya.

b. Mampu mengerjakan tugasnya.

c. Mampu beradaptasi dengan lingkungan.

d. Percaya diri dalam melakukan suatu hal.

Bertanggung jawab atas tugasnya yaitu segala sesuatu yang ditugaskan kepada seseorang tersebut langsung dikerjakan bukan untuk ditunda-tunda, mampu mengerjakan tugasnya semua tugas yang diberikan akan mampu dikerjakan dengan semaksimal mungkin, yang dimaksud mampu beradaptasi dengan lingkungan yaitu dimana seseorang bisa berbaur dengan anggota keluarga, tetangga dan teman-temannya, percaya

\footnotetext{
17.

${ }^{55}$ Suratina Tirto Negoro, Kecenderungan Hidup Mandiri, (Bandung: Tarsito, 2008), hal.

${ }^{56}$ Sc Utami Munandar, Kreatifitas dalam keberbakatan, (Jakarta: Gramedia, 2011), hal. 51.

${ }^{57}$ Muhamad Afandi dan Galuh, Pendidikan Anak Berkebutuhan Khusus, (Semarang: Unisulla Press, 2013), hal. 95.
} 
diri dalam melakukan segala hal yang dimaksud yaitu seseorang itu mau melakukan segala hal yang diperintahkan, meskipun itu nanti hasil dari pekerjaannya salah, namun mereka sudah mau mencoba melakukannya.

\section{Langkah-Langkah Menciptakan Kemandirian Belajar}

Kemandirian belajar adalah proses belajar dengan beberapa langkah-langkah. Menurut Hiemstra langkah-langkah kemandirian belajar terbagi menjadi 6 yaitu preplanning, menciptakan lingkungan belajar yang positif, mengembangkan rencana pembelajaran, mengidentifikasi aktivitas pembelajaran yang sesuai, melaksanakan kegiatan pembelajaran dan monitoring, dan mengevaluasi hasil belajar individu. ${ }^{58}$

\section{Pendidikan Karakter Kemandirian di Sekolah}

Pendidikan karakter pada dasarnya mencakup pengembangan substansi, proses, dan suasana atau lingkungan yang menggugah, mendorong, dan memudahkan seseorang untuk mengembangkan kebiasaan baik dalam kehidupan sehari-hari. Kebiasaan ini timbul dan berkembang dengan didasari oleh kesadaran, keyakinan, kepekaan, dan sikap orang yang bersangkutan. Dengan demikian, karakter yang ingin dibangun melalui pendidikan karakter bersifat inside-out, dalam arti bahwa perilaku yang berkembang menjadi kebiasaan baik ini terjadi karena adanya dorongan dari dalam, bukan karena adanya paksaan dari luar. ${ }^{59}$

Pendidikan karakter disini berusaha mengajak peserta didik untuk menghayati nilai-nilai yang ditanamkan pada mereka.

\footnotetext{
${ }^{58}$ Roger Hiemstra, More Than Three Decades of Self-Directed Learning: From Whence Have We Come?, (Adult Learning, 14, 5, 2003), hal. 1-8.

59 Zubaedi, Desain Pendidikan Karakter: Konsepsi dan Aplikasinya Dalam Lembaga Pendidikan, (Jakarta: Kencana, 2012), hal. 191.
} 
Desmita menerangkan, beberapa upaya pengembangan kemandirian peserta didik yang dapat dilaksanakan oleh sekolah, diantaranya:

a. Mengembangkan proses belajar mengajar yang demokratis, yang memungkinkan anak merasa dihargai.

b. Mendorong anak untuk berpartisipasi aktif dalam pengambilan keputusan dan dalam berbagai kegiatan sekolah.

c. Memberi kebebasan kepada anak untuk mengeksplorasi lingkungan, mendorong rasa ingin tahu mereka.

d. Penerimaan positif tanpa syarat kelebihan dan kekurangan anak, tidak membeda-bedakan anak yang satu dengan yang lain. Menjalin hubungan yang harmonis dengan anak. ${ }^{60}$

Upaya pengembangan kemandirian sebagaimana disebutkan di atas, mengisyaratkan bahwa setiap pendidik harus memiliki keterbukaan kepada peserta didik dan kedekatan dengan mereka.

Syamsul Kurniawan menyebutkan, untuk menjadi mandiri, peserta didik di lingkungan sekolah hendaknya "sesekali" dibiasakan belajar mandiri. Peserta didik mempunyai otonomi dalam belajar. Otonomi tersebut terwujud dalam beberapa kebebasan sebagai berikut:

${ }^{60}$ Desmita, Psikologi Perkembangan Peserta Didik Cet III, (Bandung: PT Remaja Rosdakarya,2011), hal. 190. 
a. Peserta didik mempunyai kesempatan untuk ikut menentukan tujuan pembelajaran yang ingin dicapai sesuai dengan kondisi dan kebutuhan belajarnya.

b. Peserta didik boleh ikut menentukan bahan belajar yang ingin dipelajarinya dan cara mempelajarinya.

c. Peserta didik mempunyai kebebasan untuk belajar sesuai dengan kecepatannya sendiri. ${ }^{61}$

Namun dalam implementasi otonomi di atas pendidik harus tetap membimbing dan mendampingi peserta didik, agar mereka tetap dalam batas-batas yang benar dalam pencapaian kompetensi yang hendak dicapai.

Membangun karakter mandiri pada peserta didik juga dapat dimulai dengan mengajarkan kemandirian dalam belajar.Hal ini supaya mereka mempunyai tanggung jawab dalam mengatur dan mendisiplinkan dirinya dan dalam mengembangkan kemampuan belajar atas kemauannya sendiri. Mohamad Mustari menjelaskan bahwa peserta didik yang mandiri adalah peserta didik yang aktif, independen, kreatif, kompeten, dan spontan. Pendapat ini dapat digunakan sebagai indikator kemandirian peserta didik.

${ }^{61}$ Syamsul Kurniawan, Pendidikan Karakter: Konsepsi dan Implementasinya Secara Terpadu di Lingkungan Keluarga, Sekolah, Perguruan Tinggi, dan Masyarakat (Jakarta: PT Rosdakarya, 2010), hal. 143. 


\section{Dampak dalam Pelaksanaan Pendidikan Karakter}

Terdapat berbagai dampak dalam pelaksanaan pendidikan karakter diantaranya Dampak pendidikan karakter terbagi menjadi dua yaitu: ${ }^{62}$

\section{Terhadap pembangunan SDM secara keseluruhan}

Pendidikan karakter sebagai pondasi pembangunan sumber daya manusia seutuhnya, dimana karakter merupakan input yang penting dalam pembangunan sumber daya manusia. Manusia selain mempunyai kecerdasan emosi juga harus mempunyai kecerdasan spiritual.

2. Terhadap keberhasilan akademik

Menunjukkan peningkatan motivasi siswa sekolah dalam meraih prestasi akademik pada sekolah yang menerapkan pendidikan karakter. Kelas-kelas yang secara komprehensif terlibat dalam pendidikan karakter menunjukkan penurunan drastis pada prilaku negatif yang menghambat keberhasilan akademik.

\section{Anak Berkebutuhan Khusus (ABK)}

\section{Pengertian Anak Berkebutuhan Khusus}

ABK merupakan istilah yang digunakan untuk menyebutkan anakanak yang memiliki keunikan tersendiri dalam jenis dan karakteristiknya. Anak berkebutuhan khusus adalah anak dengan karakteristik khusus yang berbeda dengan anak pada umumnya tanpa selalu menunjukan pada ketidakmampuan mental, emosi atau fisik. ${ }^{63} \mathrm{ABK}$ adalah anak yang memiliki kelainan penyimpangan dari kondisi rata-rata anak normal

${ }^{62}$ Kusuma dan Darma, Pendidikan Karakter Kajian Teori dan Praktik Di Sekolah, (Bandung: Rosda Karya, 2011), hal. 7.

${ }^{63}$ Nurul Hidayati Rofiah, Bimbingan Belajar Untuk Anak Berkebutuhan Khusus di Sekolah Dasar, (Prosiding Seminar Nasional dan Call for Papers), hal. 257. 
umumnya, dalam fisik, mental maupun karakteristik perilaku sosialnya atau anak yang berbeda dari rata-rata umumnya, dikarenakan ada permasalahan dalam kemampuan berpikir, penglihatan, pendengaran, sosialisasi dan bergerak. ${ }^{64} \mathrm{ABK}$ adalah mereka yang memiliki disabilitas intelektual dan perkembangan, disabilitas fisik, disabilitas sensoris (indera), hambatan/masalah perilaku, kesulitan belajar, serta cerdas dan bakat istimewa. ${ }^{65}$ Berdasarkan pendapat diatas disimpulkan ABK adalah anak yang memiliki kelainan dalam fisik, mental maupun karakteristik perilaku sosialnya yang berbeda dari rata-rata umumnya.

\section{Jenis-Jenis Anak Berkebutuhan Khusus}

Tedapat berbagai jenis ABK. Menurut Rofiah jenis-jenis ABK terdiri dari: ${ }^{66}$

a. Anak dengan gangguan penglihatan (Tunanetra)

Anak yang mengalami gangguan daya penglihataan sedemikian rupa, sehingga membutuhkaan layanan khusus dalam pendidikanmaupun kehidupannya. Layanan khusus dalam pendidikan bagi mereka, yaitu dalam membaca menulis dan berhitungdiperlukan huruf Braille bagi yang buta, dan bagi yang sedikit penglihatan (low vision)diperlukan kaca pembesar atau huruf cetak yang besar, media yang dapat diraba dan didengar atau diperbesar.

${ }^{64}$ Mohammad Efendi, Pengantar Psikopedagogik Anak Berkelainan, (Jakarta: PT Bumi Aksara, 2006), hal. 2.

${ }^{65}$ Safrudin Aziz, Pendidikan Seks bagi Anak Berkebutuhan Khusus, (Jurnal Kependidikan, Vol. 2, No. 2, 2014), hal. 183.

${ }^{66}$ Nurul Hidayati Rofiah, Bimbingan Belajar Untuk Anak Berkebutuhan Khusus di Sekolah Dasar ..., hal. 257-258. 
b. Anak dengan Gangguan Pendengaran (Tuna rungu)

Anak yang kehilangan seluruh atau sebagian daya pendengarannya sehinggamengalami gangguan berkomunikasi secara verbal. Walaupun telah diberikan pertolongandengan alat bantu dengar, mereka masih tetap memerlukan layanan pendidikan khusus.

c. Anak dengan gangguan Intelektual (Tuna grahita)

Anak yang secara nyata mengalami hambatan danketerbelakangan perkembangan mental- intelektual di bawah rata-rata, sehingga mengalamikesulitan dalam menyelesaikan tugas-tugasnya.

d. Anak dengan gangguan Gerak Anggota Tubuh (Tunadaksa)

Anak yang mengalami kelainan atau cacat yang menetap pada anggota gerak tulang, sendi, dan otot. Mereka mengalami gangguan gerak karena kelayuhan otot, atau gangguanfungsi syaraf otak (disebut Cerebral Palsy /CP].Pengertian anak Tunadaksa bisa dilihat dari segi fungsi fisiknya dan dari segi anatominya.

e. Anak dengan gangguan prilaku dan emosi (tuna laras)

Anak yang berperilaku menyimpang baik pada taraf sedang, berat dan sangat berat, terjadi pada usia anak dan remaja, sebagai akibatterganggunya perkembangan emosi dan sosial atau keduanya, sehingga merugikan dirinyasendiri maupun lingkungan, maka dalam mengembangkan potensinya memerlukan pelayanandan pendidikan secara khusus. 
f. Anak dengan Kecerdasan Tinggi dan Bakat Istimewa (Gifted and Tallented)

Anak yang memiliki potensi kecerdasan (intelegensi), kreativitas, dan tanggung jawab terhadap tugas (task commitment) di atas anakanak seusianya (anak normal), sehinggauntuk mengoptimalkan potensinya, diperlukan pelayanan pendidikan khusus.

g. Lamban belajar (slow learner)

Anak yang memiliki potensi intelektual sedikit di bawahanak normal, tetapi tidak termasuk anak tunagrahita (biasanya memiliki IQ sekitar 80-85).Dalam beberapa hal anak ini mengalami hambatan atau keterlambatan berpikir, meresponrangsangan dan kemampuan untuk beradaptasi, tetapi lebih baik dibanding dengan yangtunagrahita. Mereka membutuhkan waktu belajar lebih lama dibanding dengan sebayanya.Sehingga mereka memerlukan layanan pendidikan khusus.

\section{Penyebab Anak Berkebutuhan Khusus}

Penyebab terjadinya anak berkebutuhan khusus sangat bervariasi tergantung pada setiap jenis kelainan. Pada umumnya terjadi kecacatan atau kelainan berdasarkan terjadinya tergolong kedalam 3 macam.Yaitu disebabkan oleh faktor-faktor yang terjadi pada saat dalam kandungan, pada saat kelahiran, dan setelah kelahiran. ${ }^{67}$

a. Faktor penyebab Saat di dalam kandungan, meliputi: kelainan hereditas atau bawaan yang merupakan faktor genetika, Keracuanan pada saat di dalam kandungan, faktor psikologis, Infeksi dalam kandungan, seperti

67 Muhammad Awwad, Urgensi Layanan Bimbingan dan Konseling bagi Anak Berkebutuhan Khusus, (Al-Tazkiah, Vol. 7, No. 1, 2015), hal. 54; Nandiyah Abdullah, Mengenal Anak Berkebutuhan Khusus, (Magistra, Vol. 86, No. 25, 2013), hal. 6. 
rubella, kekurangan gizi, berbagai penyakit yang disebabkan virus seperti Shypilis HIV, kerusakan biokimia yang menyebabkan abnormalitas kromosomal.

b. Faktor saat kelahiran meliputi: pendarahan di otak, asfiksia, kerusakan bagian otak yang diakibatkan terkena penjepit, lahir dengan vacuum, sesak nafas, premature.

c. Faktor setelah kelahiran meliputi: Infeksi, Encephalitis, Meningitis, Malnutrisi, Disebabkan kecelakaan, Perkembangannya yang lambat.

\section{E. Metode Pembiasaan}

\section{Pengertian Metode Pembiasaan}

Metode pembiasaan dapat diartikan sebagai sebuah cara yang dapat dilakukan untuk membiasakan anak didik berfikir, bersikap dan bertindak sesuai dengan tuntutan ajaran islam. Pembiasaan dinilai efektif jika penerapannya dilakukan terhadap peserta didik. Karean memiliki rekaman ingatan yang kuat dan kondisi kepribadian yang belum matang, sehingga mereka mudah terlarut dengan kebiasaan kebiasaan yang mereka lakukan sehari-hari. $^{68}$

Dalam bidang psikologi pendidikan, metode pembisaan dikenal dengan istilah operan conditioning, mengajarkan peserta didik untuk membiasakan perilaku terpuji, disiplin, giat belajar, bekerja keras, ikhlas, jujur, dan bertanggung jawab atas setiap tugas yang telah diberikan. Pembiasaan adalah sesuatu yang sengaja dilakukan secara berulang-ulang agar sesuatu itu dapat menjadi kebiasaan. Pembiasaan sebenarnya 
berintikan pengalaman, yang dibiasakan adalah sesuatu yang diamalkan.

Pembiasaan menentukan manusia sebagai sesuatu yang diistemawakan, yang dapat menghemat kekuatan, karena akan menjadi kebiasaan yang melekat dan spontan agar kekuatan itu dapat dipergunakan untuk berbagai kegiatan dalam setiap pekerjaan dan aktivitas lainnya. ${ }^{69}$

Pembiasaan merupakan upaya praktis dalam pendidikan dan pembinaan anak. Hasil dari pembiasaan yang dilakukan seorang pendidik adalah terciptanya suatu kebiasaan bagi anak didiknya. Seorang anak yang terbiasa melakukan kebiasaan- kebiasaan yang baik maka anak tersebut menjadi anak yang mudah diatur dalam hal positif. Pembiasaan yang dilakukan sejak dini akan membawa kegemaran dan kebiasaan yang menjadi bagian tidak terpisahkan dari kepribadiannya. Al- Ghazali mengatakan:

Anak adalah amanah orang tuanya, hatinya yang bersih adalah permata berharga nan murni, yang kosong dari setiap tulisan dan gambar. Hati itu siap menerima setiap tulisan dan cenderung pada setiap yang ia inginkan. Oleh karena itu, jika dibiasakan mengerjakan yang baik, lalu tumbuh di atas kebaikan itu maka bahagialah ia didunia dan akhirat, orang tuanya pun mendapat pahala bersama. ${ }^{70}$

Ciri khas daripada metode pembiasaan adalah kegiatan yang berupa pengualangan yang berkali-kali dari suatu hal yang sama. Pengulangan ini sengaja dilakukan berkali-kali supaya asosiasi antara srimulus dengan respon menjadi sangat kuat. Atau dengan kata lain, tidak

\footnotetext{
${ }^{69}$ Mulyasa, ed. Dewi Ispurwanti, Manajemen Pendidikan Karakter, (Jakarta: Bumi Aksara, 2003), hal. 166.

${ }^{70}$ Muhammad Rabbi dan Muhammad Jauhari, Akhlaquna, terjemahan. Dadang Sobar Ali, (Bandung : Pustaka Setia, 2006), hal. 109.
} 
mudah dilupakan. Dengan demikian, terbentuklah pengetahuan siap atau ketrampilan siap yang setiap saat siap untuk dipergunakan oleh yang bersangkutan.

Metode pembiasaan perlu diterapkan oleh guru dalam proses pembentukan karakter, untuk membiasakan peserta didik dengan sifatsifat terpuji dan baik, sehingga aktivitas yang dilakukan oleh peserta didik terekam secara positif.

Pendidikan melalui pembiasaan dapat dilaksanakan sebagai berikut:

a. Kegiatan terprogram dalam pembelajaran dapat dilaksanakan dengan perencanaan khusus dalam kurun waktu tertentu untuk mengembangkan pribadi peserta didik secara individual, kelompok, dan atau klasikal antara lain:

1) Biasakan peserta didik untuk bekerja sendiri, menemukan sendiri, dan mengkonstrusi sendiri pengetahuan, ketrampilan, dan sikap baru dalam setiap pembelajaran.

2) Biasakan peserta didik untuk bertanya dalam setiap pembelajaran.

3) Biasakan peserta didik untuk bertnaya dalam setiap pembelajaran.

4) Biasakan peserta didik bekerjasama, dan saling menunjang.

5) Biasakan peserta didik untuk berani menanggung resiko. 
b. Kegiatan pembiasaan secara tidak terprogram dapat dilaksanakan sebagai berikut:

1) Rutin, yaitu pembiasaan yang dilakukan terjadwal. Seperti: upacara bendera, senam, shalat berjamah, pemeliharaan kebersihan, dan kesehatan diri.

2) Spontan, adalah pembiasaan tidak terjadwal dalam kejadian khusus. Seperti: pembentukan perilaku memberi salam, membuang sampah pada tempatnya, antre, mengatasi silang pendapat.

3) Keteladanan, adalah pembiasaan dalam bentuk perilaku seharihari. Seperti: berpakaian rapi, berbahasa yang baik, rajin membaca, memuji kebaikan dan atau keberhasilan orang lain, datang tepat waktu. $^{71}$

$$
\text { Penerapan metode pembiasaan dapat dilakukan dengan }
$$

membiasakan anak untuk mengerjakan hal-hal positif dalam keseharian mereka. Dengan melakukan kebiasaan-kebiasaan secara rutinitas setiap harinya, anak didik akan melakukan dengan sendirinya, dengan sadar tanpa ada paksaan. Dengan pembiasaan secara langsung, anak telah diajarkan disiplin dalam melakukan dan menyelesaikan suatu kegiatan.

\section{Landasan Metode Pembiasaan}

Dalam teori perkembangan anak didik, dikenal dengan adanya teori konvergensi, dimana pribadi dapat dibentuk oleh lingkungannya dan dengan mengembangkan potensi dasar yang ada padanya. Potensi dasar ini

\footnotetext{
${ }^{71}$ Mulyasa, ed. Dewi Ispurwanti, Manajemen Pendidikan Karakter..., hal. 169.
} 
dapat menjadi penentu tingkah laku. Oleh karena itu, potensi dasar harus selalu diarahkan agar tujuan pendidikan dapat tercapai dengan baik. Salah satu cara yang dapat dilakukan untuk mengembangkan potensi dasar tersebut adalah melalui kebiasaan yang baik.

Pendekatan pembiasaan sesungguhnya sangat efektif dalam menanamkan nilai-nilai positif kedalam diri anak didik, baik pada aspek kognitif, afektif dan psikomotorik. Selain itu, pendekatan pembiasaan juga dinilai sangat efektif dalam mengubah kebiasaan negative menjadi positif. Namun demikian, pendekatan ini jauh dari keberhasilan jika tidak diiringi dengan contoh tauladan yang baik dari si pendidik. ${ }^{72}$

\section{Dasar dan Tujuan Pembiasaan}

a. Dasar Pembiasaan

Pembiasaan merupakan salah satu metode pendidikan yang sangat penting, terutama bagi anak-anak. Mereka belum menginsafi apa yang disebut baik dan buruk dalam arti susila. Mereka juga belum mempunyai kewajiban-kewajiban yang harus dikerjakan seperti pada orang dewasa. Sehingga mereka perlu dibiasakan dengan tingkah laku, keterampilan, kecakapan, dan pola pikir tertentu. Anak perlu dibiasakan pada sesuatu yang baik. Lalu mereka akan mengubah seluruh sifat-sifat baik menjadi kebiasaan, sehingga jiwa dapat menunaikan kebiasaan itu tanpa terlalu payah, tanpa kehilangan banyak tenaga, dan tanpa menemukan banyak kesulitan. ${ }^{73}$

\footnotetext{
${ }^{72}$ Armai Arief, Pengantar Ilmu dan Metodologi Pendidikan Islam ..., hal. 114.

${ }^{73}$ Abudin Nata, Filsafat Pendidikan Islam, (Jakarta: Logos Wacana Ilmu, 1997), hal.10.
} 
Para ahli pendidikan senantiasa mengingatkan agar anak-anak segera dibiasakan dengan sesuatu yang diharapkan menjadi kebiasaan yang baik sebelum terlanjur mempunyai kebiasaan lain yang berlawanan dengannya.

b. Tujuan Pembiasaan

Pembiasaan adalah proses pembentukan kebiasaan- kebiasaan baru atau perbaikan kebiasaan-kebiasaan yang telah ada. Belajar kebiasaan, selain menggunakan perintah, suri tauladan dan pengalaman khusus juga menggunakan hukuman dan ganjaran. Tujuannya agar siswa memperoleh sikap-sikap dan kebiasaan- kebiasaan perbuatan baru yang lebih tepat dan positif dalam arti selaras dengan kebutuhan ruang dan waktu (kontekstual). Selain itu arti tepat dan positif di atas ialah selaras dengan norma dan tata nilai moral yang berlaku baik yang bersifat religius maupun tradisional dan kultural.

c. Langkah- langkah Pembiasaan

Langkah-langkah pembiasaan yaitu pendidik hendaknya sesekali memberikan motivasi dengan kata-kata yang baik dan sesekali dengan petunjuk-petunjuk. Suatu saat dengan memberi peringatan dan kabar gembira. Kalau memang diperlukan, pendidik boleh memberi sanksi jika ia melihat ada kemaslahatan bagi anak guna meluruskan penyimpangan dan pada saat yang lain dengan penyelewengannya. Semua langkah tersebut memberikan arti positif dalam membiasakan anak dengan keutamaan-keutamaan jiwa, akhlak mulia dan tata cara sosial. 


\section{Bentuk- bentuk Pembiasaan}

Metode pembiasaan di sekolah adalah untuk melatih serta membiasaakan anak didik secara konsisten dan kontinyu dengan sebuah tujuan, sehingga benar-benar tertanam pada diri anak dan akhrinya menjadi kebiasaan yang sulit ditinggalkan. Bentuk-bentuk pembiasaan dalam pendidikan dapat dilakukan dalam berbagai bentuk diantaranya yaitu:

a. Pembiasaan dalam akhlak, berupa pembiasaan bertingkah laku yang baik, baik di sekolah maupun di luar sekolah.

b. Pembiasaan dalam beribadah, berupa pembiasaan solat berjamaah di sekolah, mengucapkan salam sewaktu masuk dan keluar kelas, serta membaca basmallah dan hamdalah ketika akan memulai pembelajaran dan mengakhiri pembelajaran.

c. Pembiasaan dalam keimanan, berupa pembiasaan agar anak beriman dengan sepenuh jiwa. ${ }^{74}$

\section{Kelebihan dan Kekurangan Metode Pembiasaan}

Sebagaimana metode-metode lainnya didalam proses pendidikan, metode pembiasaan tidak bisa terlepas dari dua aspek yang saling bertentangan yaitu kelebihan dan kekurangan adapun penjabaran kelebihan dan kekurangan metode pembiasaan yaitu:

${ }^{74}$ Muhibbin Syah, Psikologi Pendidikan Dengan Pendekatan Baru, (Bandung: PT Remaja Rosdakarya, 2010), hal. 123. 
a. Kelebihan metode ini antara lain:

1) Dapat menghemat tenaga dan waktu dengan baik.

2) Pembiasaan tidak hanya berkaitan dengan lahiriyah aspek tetapi juga berhubungan dengan aspek batiniah.

3) Pembiasaan dalam sejarah tercatat sebagai metode yang paling berhasil dalam pembentuan kepribadian anak didik.

b. Kekurangan metode ini antara lain:

1) Apabila telah tertanam kebiasaan buruk,sulit untuk dihilangkan.

2) Memerlukan pengawasan, supaya kebiasaan yang dilakukan tidak menyimpang.

3) Membutuhkan stimulus atau rangsangan, supaya anak dapat melakukan kebiasaan baiknya dengan istiqamah. ${ }^{75}$

Dengan adanya kekurangan di atas bisa diminimalisir dengan cara hanya latihan untuk bahan atau tindakan yang otomatis, latihan harus memiliki arti yang luas dan dijelaskan secara detail, masa latihan harus relatif singkat tetapi harus sering dilakukan pada waktu-waktu tertentu.

\section{F. Strategi Guru}

\section{Pengertian Strategi Guru}

Istilah strategi berasal dari bahasa Yunani yaitu strategia, strategi merupakan sebuah perencanaan yang panjang untuk berhasil dalam mencapai suatu keuntungan. Strategi didefinisikan sebagai suatu garis

\footnotetext{
${ }^{75}$ Muhammad Fadlillah dan Lilif Mualifatu Khorida, Pendidikan Karakter Anak Usia Dini: Konsep dan Aplikasinya dalam PAUD, (Jogjakarta: Ar-Ruzz Media, 2013), hal. 172.
} 
besar haluan bertindak untuk mencapai sasaran yang telah ditetapkan. ${ }^{76}$ Menurut Andi Muhammad asbar strategi diartikan sebagai perencanaan yang berisi tentang rangkaian kegiatan yang didesain untuk mencapai tujuan tertentu. Strategi merupakan tehnik atau siasat yang digunakan guru dan diperagakan oleh guru dan siswa dalam berbagai peristiwa pembelajaran untuk mewujudkan tujuan pembelajaran agar lebih efektif dan efisien. ${ }^{77}$ Dalam bukunya Wina Sanjaya menjelaskan bahwa strategi menunjuk pada sebuah perencanaan untuk mencapai sesuatu, sedangkan metode adalah cara yang dapat digunakan untuk melaksanakan strategi. ${ }^{78}$ Guru adalah pendidik profesional dengan tugas utama mendidik,mengajar, membimbing, mengarahkan, melatih, menilai, dan mengevaluasi peserta didik pada pendidikan anak usia dini jalur pendidikan formal, pendidikan dasar dan pendidikan menengah. ${ }^{79}$ Guru merupakan tenaga pendidikan yang profesional pedagogis merupakan tanggung jawab besar di dalam proses pembelajaran menuju keberhasilan pendidikan khususnya keberhasilan siswanya untuk masa depannya.

Jika dihubungkan dengan belajar mengajar, strategi bisa diartikan sebagai pola umum kegiatan guru dan murid dalam mewujudkan belajar mengajar untuk mencapai tujuan yang telah digariskan.

\footnotetext{
${ }^{76}$ Martinis Yamin, Strategi dan Metode Dalam Model Pembelajaran, Referensi, (Jakarta: Gp Press Goup, Ciputat, 2013), hal. 1.

77 Andi Muhammad Asbar, Strategi Guru dalam Pengelolaan Kelas pada Pembelajaran Pendidikan Agama Islam di Smp Negeri 39 Bulukumba, (Jurnal Ilmiah Al Qalam, Vol. 12, No. 1, 2018), hal. 89-112.

${ }^{78}$ Wina Sanjaya, Strategi Pembelajaran Berorientasi Standar Proses Pendidikan, (Jakarta: Kencana, 2007), hal. 126.

79 Kunandar, Guru Profesional Implementasi Kurikulum Tingkat Satuan Pendidikan (KTSP), (Jakarta: PT Raja Grafindo Persada, 2009), hal. 54.
} 
Strategi dasar dari setiap usahanya ada empat hal yaitu:

a. Pengidentifikasian dan penetapan spesifikasi dan kualifikasi yang harus dicapai dan menjadi sasaran usaha tersebut dengan mempertimbangkan aspirasi rakyat yang memerlukannya.

b. Pertimbangan dan penetapan pendekatan utama yang ampuh untuk mencapai sasaran.

c. Pertimbangan dan penetapan langkah-langkah yang ditempuh sejak awal sampai akhir.

d. Pertimbangan dan penetapan tolak ukur dan ukuran baku yang akan digunakan untuk menilai keberhasilan usaha yang dilakukan. ${ }^{80}$

Kalau diterapkan dalam konteks pendidikan, keempat strategi dasar tersebut bisa diterjemahkan menjadi :

a. Mengidentifikasi serta menetapkan spesifikasi dan kualifikasi perubahan tingkah laku dan kepribadian anak didik sebagaimana yang diharapkan.

b. Memilih sistem pendekatan belajar mengajar berdasarkan aspirasi dan pandangan hidup masyarakat.

c. Memilih dan menetapkan prosedur, metode dan teknik belajar mengajar yang dianggap paling tepat dan efektif.

d. Menetapkan norma-norma dan batas minimal keberhasilan atau standar keberhasilan dalam pendidikan.

${ }^{80}$ Anissatul Mufarokah, Strategi dan Model-model Pembelajaran, (Tulungagung, STAIN Press, 2013), hal. 1. 
Dalam pelaksanaan pembelajaran peserta didik diharapkan mengerti dan paham tentang strategi pembelajaran untuk mempermudah proses pembelajaran sehingga dapat mencapai hasil yang maksimal.

\section{Strategi Guru dalam Implementasi Pendidikan Karakter}

\section{a. Langkah-langkah implementasi pendidikan karakter di sekolah}

Strategi guru dalam implementasi pendidikan karakter di sekolah meliputi langkah-langkah ${ }^{81}$ sebagai berikut.

1) Integrasi dalam Mata Pelajaran

Setiap mata pelajaran terdapat muatan nilai-nilai karakter yang perlu dikembangkan, dieksplisitkan, dikaitkan dengan konteks kehidupan sehari-hari. Dengan demikian, pembelajaran nilai-nilai karakter tidak hanya pada tataran kognitif, tetapi menyentuh pada internalisasi, dan pengamalan nyata dalam kehidupan siswa sehari-hari di masyarakat.

\section{2) Integrasi dalam Muatan Lokal}

Muatan lokal adalah bahan kajian atau mata pelajaran pada satuan pendidikan yang berisi muatan dan proses pembelajaran tentang potensi dan keunikan lokal yang dimaksudkan untuk membentuk pemahaman peserta didik terhadap keunggulan dan kearifan di daerah tempat tinggalnya.

Muatan lokal diajarkan dengan tujuan membekali siswa dengan sikap, pengetahuan, dan keterampilan yang diperlukan untuk mengenal dan mencintai lingkungan alam, sosial, budaya, dan spiritual di

81 Kemdiknas, Panduan Pelaksanaan Pendidikan Karakter, (Jakarta: Pusbukur Kemendiknas, 2011), hal. 15. 
daerahnya, dan melestarikan dan mengembangkan keunggulan dan kearifan daerah yang berguna bagi diri dan lingkungannya dalam rangka menunjang pembangunan nasional.

Nilai-nilai karakter yang dapat dikembangkan melalui pembelajaran muatan lokal antara lain: peduli lingkungan, peduli sosial, cinta tanah air, rasa ingin tahu, kerja keras, kreatif dan mandiri.

3) Pengembangan budaya dan pusat kegiatan belajar

Pengembangan budaya sekolah dan pusat kegiatan belajar dilakukan melaui kegiatan pengembangan diri, yang meliputi:

a) Pengkondisian, yaitu penciptaan kondisi yang mendukung keterlaksanaan pendidikan karakter, misalnya kebersihan badan dan pakaian, toilet yang bersih, tersedianya tempat sampah, halaman yang hijau dengan pepohonan, poster kata-kata bijak di sekolah dan di dalam kelas.

b) Kegiatan rutin, yaitu kegiatan yang dilakukan siswa secara terus menerus dan konsisten setiap saat, misalnya kegiatan upacara hari senin, upacara besar kenegaraan, pemeriksaan kebersihan badan, piket kelas, shalat berjamaah, berbaris ketika masuk kelas, berdoa sebelum pelajaran dimulai dan diakhiri, dan mengucapkan salam apabila bertemu guru, tenaga pendidik dan teman.

c) Kegiatan Spontanitas, yaitu kegiatan yang dilakukan siswa secara spontan pada saat itu juga, misalnya, mengumpulkan sumbangan ketika ada teman yang terkena musibah atau sumbangan untuk masyarakat ketika terjadi bencana. 
d) Keteladanan, yaitu perilaku, sikap guru, tenaga kependidikan dan siswa dalam memberikan contoh melalui tindakan-tindakan yang baik sehingga diharapkan menjadi panutan bagi siswa lain, misalnya nilai disiplin (kehadiran guru yang lebih awal dibanding siswa), kebersihan, kerapihan, kasih sayang, kesopanan, perhatian, jujur, kerja keras dan percaya diri.

4) Kegiatan Pembelajaran

Salah satu upaya untuk mengintegrasikan nilai-nilai karakter dalam kegiatan pembelajaran adalah dengan merancang dan menerapkan pendekatan atau strategi pembelajaran aktif atau pembelajaran yang berpusat pada peserta didik. Beberapa pendekatan dan strategi pembelajaran yang dapat digunakan untuk mengintegrasikan nilai-nilai karakter dalam kegiatan pembelajaran antara lain; pendekatan kontekstual, pendekatan saintifik, pembelajaran discovery, pembelajaran berbasis masalah, pembelajaran berbasis proyek dan strategi pembelajaran lainnya yang berbasis aktivitas.

Kegiatan ekstra kurikuler yang selama ini diselenggarakan sekolah merupakan salah satu media yang potensial untuk pembinaan karakter dan peningkatan mutu akademik peserta didik. Menurut Permendikbud nomor 62 Tahun 2014, kegiatan ekstrakurikuler adalah kegiatan kurikuler yang dilakukan oleh peserta didik di luar jam belajar kegiatan intrakurikuler dan kegiatan kokurikuler, di bawah bimbingan dan pengawasan satuan pendidikan. Kegiatan ekstrakurikuler diselenggarakan dengan tujuan untuk mengembangkan potensi, bakat, 
minat, kemampuan, kepribadian, kerjasama, kemandirian serta nilainilai karakter peserta didik secara optimal dalam rangka mendukung pencapaian tujuan pendidikan nasional. ${ }^{82}$

\section{b. Strategi implementasi pendidikan karakter di sekolah}

Strategi Implementasi Pendidikan Karakter di Sekolah sebagai berikut. $^{83}$

1) Dengan mengintegrasikan konten kurikulum pendidikan karakter yang telah dirumuskan ke dalam seluruh mata pelajaran yang relevan, terutama mata pelajaran agama, kwarganegaraan, dan bahasa (baik bahasa Indonesia maupun bahasa daerah).

2) Dengan mengintegrasikan pendidikan karakter ke dalam kegiatan sehari-hari di sekolah.

3) Dengan mengintegrasikan pendidikan karakter ke dalam kegiatan yang diprogramkan atau direncanakan.

Agar implementasi pendidikan karakter di sekolah dapat berhasil, maka syarat utama yang harus dipenuhi, ${ }^{84}$ diantaranya: teladan dari guru, karyawan, pimpinan sekolah dan para pemangku kebijakan di sekolah, pendidikan karakter dilakukan secara konsisten dan secara terus-menerus, penanaman nilai-nilai karakter yang utama. Karena semua guru dalah guru pendidikan, maka mereka memiliki kewajiban untuk memasukkan atau menyelipkan nilai-nilai pendidikan karakter dalam kegiatan pembelajarannya (intervensi).

\footnotetext{
${ }^{82}$ Permendikbud Nomor 62 Tahun 2014 tentang Kegiatan Ekstrakurikuler.

${ }^{83}$ Siti Nurchotimah, Implementasi Kurikulum Pendidikan Berkarakter di Sekolah, (Seminar Nasional Evaluasi Pendidikan Tahun 2013 di Unes, 2013), hal. 219.

84 Agus Wibowo, Pendidikan Karakter Strategi Membangun Karakter Bangsa Berperadaban, (Yogyakarta: Pustaka Belajar, 2012), hal. 201.
} 
Darmiyati Zuchdi sendiri telah memberikan beberapa strategi yang dapat digunakan dalam mengimplementasikan pendidikan karakter di sekolah secara efektif dan efisien yaitu: ${ }^{85}$ Tujuan, sasaran, dan target yang akan dicapai harus jelas dan konkret, ada kerjasama antara pihak sekolah dengan orang tua siswa, Menyadarkan pada semua guru akan peran yang penting dan bertanggung jawab dalam keberhasilan melaksanakan dan mencapai tujuan pendidikan karakter, Kesadaran guru akan perlunya "hidden curriculum".

Dalam masing-masing pilar pendidikan akan ada dua jenis pengalaman belajar yang dibangun melalui dua pendekatan yakni intervensi dan habituasi. ${ }^{86}$ Dintervensi dikembangkan suasana interaksi belajar dan pembelajaran yang sengaja dirancang untuk mencapai tujuan pembentulkan karakter dengan menerapkan kegiatan yang terstruktur. Agar proses pembelajaran tersebut berhasil guna, peran guru sebagai sosok panutan sangat penting dan menentukan. Sementara itu dalam habituasi diciptakan situasi dan kondisi dan penguatan yang memungkinkan peserta didik pada satuan pendidikannya, di rumahnya, di lingkungan masyarakatnya membiasakan diri berperilaku sesuai nilai dan menjadi karakter yang telah diinternalisasi dan dipersonalisasi dari dan melalui proses intervensi. Proses pembudayaan dan pemberdayaan yang mencakup pemberian contoh, pembelajaran, pembiasaan, dan penguatan harus dikembangkan secara sistemik, holistik, dan dinamis.

85 Darmiyati Zuchdi, dkk. Pendidikan Karakter: Konsep Dasar dan Implementasi di Perguruan Tinggi, (Yogyakarta: UNY Press, 2013), hal. 26.

${ }^{86}$ Pemerintah Republik Indonesia, Kebijakan Nasional Pembangunan Karakter Bangsa, (Jakarta: Pemerintah Repubilk Indonesia, 2010). 
Pelaksanaan pendidikan karakter dimulai dengan pengkondisian lingkungan sekolah, pelaksanaan kegiatan pengembangan diri meliputi bimbingan konseling dan kegiatan ekstrakurikuler, serta kegiatan pembiasaan dan keteladanan yang dilakukan secara rutin, ${ }^{87}$

\section{G. Strategi Guru dalam Perspektif Islam}

QS. Ali Imran ayat 104:

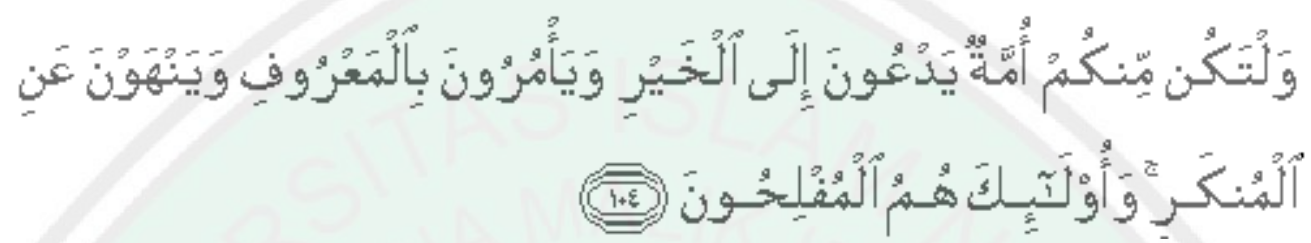

Artinya: Dan hendaklah ada di antara kamu segolongan umat yang menyeru kepada kebajikan, menyuruh kepada yang ma'ruf dan mencegah dari yang munkar merekalah orang-orang yang beruntung.

QS.al-Nahl ayat 125:

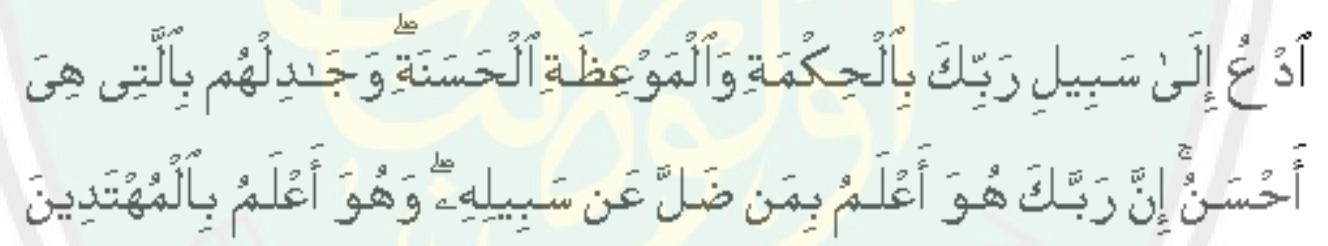

Artinya: Serulah (manusia) kepada jalan Tuhan-mu dengan hikmah dan pelajaran yang baik dan bantahlah mereka dengan cara yang baik. Sesungguhnya Tuhanmu Dialah yang lebih mengetahui tentang siapa yang tersesat dari jalan-Nya dan Dialah yang lebih mengetahui orang-orang yang mendapat petunjuk.

${ }^{87}$ Sriyanto, Pengelolaan Pendidikan Karakter pada Kegiatan Pengembangan Diri di SD Muhammadiyah 1 Wonogiri, Tesis, Program Pascasarjana, Universitas Muhammadiyah Surakarta, 2013, hal. 14. 


\section{H. Pendidikan Karakter dalam Perspektif Islam}

QS. al-Ahzab ayat 21:

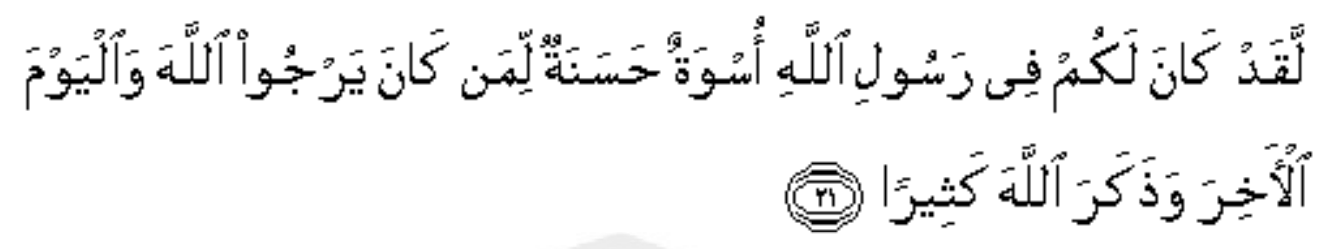

Artinya: Sesungguhnya telah ada pada (diri) Rasulullah itu suri teladan yang baik bagimu (yaitu) bagi orang yang mengharap (rahmat) Allah dan (kedatangan) hari kiamat dan dia banyak menyebut Allah.

Nabi Muhammad SAW diutus adalah agar supaya menjadi contoh bagi seluruh umat karena kekuatan karakter kepribadiannya telah menjadikan beliau sebagai sosok yang harus diteladani.

Hadits HR. Ahmad:

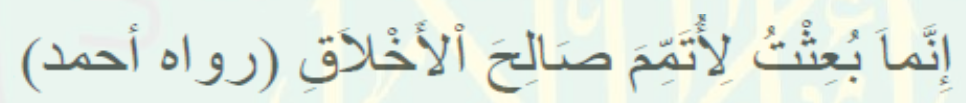

Artinya: Bahwasanya aku diutus Allah untuk menyempurnakan keluhuran akhlak (budi pekerti).

Guru telah berperan sebagai penerus perjuangan Nabi dalam mengajarkan akhlak serta menanamkan karakter pada peserta didiknya sebagaimana tercantum dalam tujuan pendidikan nasional. 


\section{Kerangka Pikir Penelitian}

Kerangka berpikir merupakan penjelasan sementara terhadap suatu gejala yang menjadi objek permasalahan penelitian.

Strategi Guru Dalam Membentuk Karakter Kemandirian Belajar Siswa Berkebutuhan Khusus Melalui Metode Pembiasaan Di SLB Tunarungu Negeri Tulungagung

Fokus Penelitian

1. Bagaimana strategi guru dalam pembentukan karakter kemandirian belajar pada siswa berkebutuhan khusus melalui metode pembiasaan di SDLB Tunarungu Negeri Tulungagung?

2. Bagaimana pelaksanaan strategi guru dalam pembentukan karakter kemandirian belajar pada siswa berkebutuhan khusus melalui metode pembiasaan di SDLB Tunarungu Negeri Tulungagung?

3. Apa dampak dalam pembentukan karakter kemandirian belajar pada siswa berkebutuhan khusus melalui metode pembiasaan di SDLB Tunarungu Negeri Tulungagung?

\section{Tujuan Penelitian}

1. Mengungkap strategi guru dalam pembentukan karakter kemandirian belajar pada siswa berkebutuhan khusus melalui metode pembiasaan di SDLB Tunarungu Negeri Tulungagung.

2. Mengungkap pelaksanaan strategi guru dalam pembentukan karakter kemandirian belajar pada siswa berkebutuhan khusus melalui metode pembiasaan di SDLB Tunarungu Negeri Tulungagung.

3. Mengungkap dampak dalam pembentukan karakter kemandirian belajar pada pada siswa berkebutuhan khusus melalui metode pembiasaan di SDLB Tunarungu Negeri Tulungagung.

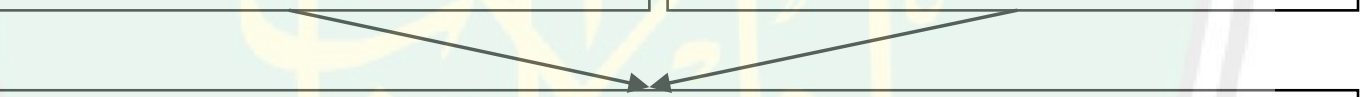

Kajian Pustaka

Pendidikan karakter, kemandirian belajar, strategi guru, metode pembiasaan dan anak berkebutuhan khusus.

\begin{tabular}{|c|c|}
\hline $\begin{array}{c}\text { Pendekatan dalam penelitian ini } \\
\text { pendekatan kualitatif dan jenis } \\
\text { penelitian ini menggunakan } \\
\text { Deskriptif }\end{array}$ \\
\hline \begin{tabular}{c} 
Latar penelitian ini dilakukan di \\
Sekolah Dasar Luar Biasa \\
Tunarungu Negeri tulungagung \\
\hline Tekhnik pengumpulan \\
data \\
Observasi,Wawancara \\
dan Dokumentasi
\end{tabular} & $\begin{array}{c}\text { Kehadiran peneliti bertindak } \\
\text { sebagai instrumenpenelitian. } \\
\text { penelitian } \\
\text { perpanjangan } \\
\text { waktu dan } \\
\text { triangulasi }\end{array}$ \\
$\begin{array}{c}\text { Pengecekan data utama adalah } \\
\text { kepala sekolah, wakil } \\
\text { kurikulum, guru wali kelas, } \\
\text { siswa, }\end{array}$ \\
$\begin{array}{c}\text { Tehnik Analisis } \\
\text { data } \\
\text { Pengumpulan } \\
\text { Data,Reduksi } \\
\text { Data }\end{array}$ \\
\hline
\end{tabular}

Gambar 3.1 Kerangka Pikir Penelitian 


\section{BAB III}

\section{METODE PENELITIAN}

\section{A. Pendekatan dan Jenis Penelitian}

Penelitian ini digunakan untuk memaparkan realitas yang ada tentang strategi yang digunakan guru dalam membentuk karakter kemandirian belajar siswa berkebutuhan khusus di SDLB, untuk mencapai tujuan itu peneliti terjun langsung ke lapangan, peneliti bertemu dengan kepala sekolah, guru serta murid untuk mengumpulkan data, sekaligus melakukan analisis data. Untuk itu peneliti menggunakan penelitian pendekatan kualitatif. Menurut Sugiyono penelitian kualitatif adalah suatu metode penelitian yang digunakan untuk meneliti pada kondisi objek yang alamiah. ${ }^{88}$

Adapun jenis penelitian yang digunakan dalam penelitian ini yaitu deskriptif berupa kata-kata tertulis dari orang-orang dan prilaku yang dapat diamati. Menurut Sugiyono penelitian diskriptif adalah penelitian yang dilakukan untuk mengetahui nilai variabel mandiri, baik satu variabel atau lebih (independen) tanpa membuat perbandingan, atau menghubungkan dengan variabel yang lain. ${ }^{89}$

\section{B. Kehadiran Peneliti}

Peneliti berperan sebagai instrumen kunci dalam penelitian ini. Peneliti selaku instrumen utama masuk ke latar penelitian supaya dapat berhubungan langsung dengan informan, dapat memahami secara alami kenyataan yang ada di

${ }^{88}$ Sugiyono, Metode Penelitian Pendidikan Pendekatan Kuantitatif, Kualitatif Dan R\&D., (Bandung: Alfabeta, 2014), hal. 112.

${ }^{89}$ Sugiyono, Metode Penelitian Pendidikan Pendekatan Kuantitatif, Kualitatif Dan R\&D $\ldots, 113$. 
latar penelitian, dapat mengamati langsung proses pembelajaran yang dilakukan. Peneliti berusaha melakukan interaksi dengan informan penelitian secara wajar dan menyikapi segala perubahan yang terjadi di lapangan, berusaha menyesuaikan diri dengan situasi yang ada di SDLB. Peneliti melakukan pengumpulan data dan peneliti mengamati terjadinya proses pembelajaran.

\section{Lokasi Penelitian}

Lokasi yang dijadikan tempat penelitian yaitu SDLB Tunarungu Negeri Tulungagung. Penetapan lokasi penelitian dalam penelitian ini dilakukan secara purposif. Pemilihan lokasi penelitian dilandasi oleh pertimbangan bahwa SDLB Tunarungu Negeri Tulungagung merupakan satu-satunya SDLB di Kabupaten Tulungagung yang menangani khusus anak tuna rungu tanpa dicampur dengan anak berkebutuhan khusus lainnya, situasi dan kondisi sekolah kondusif untuk dijadikan lokasi penelitian karena SDLB Tunarungu Negeri Tulungagung merupakan sekolah negeri sehingga tidak ada pengaruh dari yayasan tertentu.

\section{Sumber Data}

Data adalah keterangan yang benar dan nyata yang bisa diartikan sebagai keterangan atau bahan yang nyata untuk dijadikan dasar kajian atau kesimpulan. Data dalam penelitian disini merupakan segala informasi yang dapat diambil sebagai bahan untuk merumuskan hasil yang berkaitan dengan masalah yang akan diteliti pada sekolah tersebut.

Data menurut cara memperolehnya dikelompokkan menjadi dua yaitu:

1. Data Primer

Data primer merupakan data yang langsung dari nara sumber yang dilakukan dengan jalan mengadakan wawancara, pada penelitian ini orang- 
orang yang terlibat langsung dalam pembentukan karakter kemandirian belajar siswa diantaranya kepala sekolah, wakil kurikulum, guru wali kelas 1 dan 4 di Sekolah Dasar Luar Biasa Tunarungu Negeri Tulungagung

2. Data Sekunder

Data sekunder adalah data yang diperoleh dari studi dokumentasi yang di peroleh dari Sekolah Dasar Luar Biasa Tunarungu Negeri Tulungagung, literasi dan bacaan yang sesuai dengan tema penelitian. Data sekunder merupakan sumber data yang bersifat mendukung, dapat berupa dokumen, laporan, program kerja, dan arsip-arsip yang ada di Sekolah Dasar Luar Biasa Tunarungu Negeri Tulungagung.

\section{E. Teknik Pengumpulan Data}

1. Wawancara

Wawancara digunakan untuk mengumpulkan data tentang bentukbentuk strategi guru, implementasi stategi guru dan dampak yang dihadapi guru dalam pelaksanaan strategi untuk membentuk karakter kemandirian belajar. Wawancara dilakukan kepada kepala sekolah, wakil kurikulum dan 2 guru yaitu guru kelas 1 dan 4 .

Wawancara dilakukan secara terstruktur dan tidak terstruktur. Wawancara terstruktur yang dimaksud dalam penelitian ini yaitu wawancara yang pertanyaannya ditentukan oleh peneliti dan jawabannya terikat pada pedoman wawancara. Wawancara tidak terstruktur dalam penelitian ini yaitu wawancara yang dilakukan menggunakan pengembangan pertanyaan tanpa batasan dan jawaban yang tidak terikat pada pedoman wawancara. 
Wawancara dilakukan menggunakan lembar wawancara. Hasil wawancara dianalisis menggunakan lembar identifikasi hasil wawancara. Waktu pelaksanaan wawancara ditentukan sesuai kesepakatan antara peneliti dengan guru. Hasil wawancara juga akan diuji menggunakan trianggulasi sumber yaitu membandingkan hasil wawancara antara guru. Hasil wawancara juga diuji keabsahanya menggunakan trianggulasi metode yaitu dengan cara membandingkan hasil wawancara dengan hasil observasi dan studi dokumen. Hasil wawancara akan ditidaklanjuti dengan metode observasi dan studi dokumen dengan maksud untuk melengkapi data.

2. Observasi

Observasi digunakan untuk mengumpulkan data tentang implementasi pendidikan karakter dan dampak dalam implenetasi pendidikan karakter kemandirian belajar. Observasi dilakukan pada saat guru mengajar di kelas dan aktivitas sehari-hari di sekolah.

Observasi dilakukan secara terstruktur menggunakan lembar lembar observasi. Hasil observasi dianalisis menggunakan lembar identifikasi hasil observasi. Waktu pelaksanaan observasi ditentukan oleh peneliti dengan guru. Hasil observasi diuji keabsahan data menggunakan trianggulasi metode yaitu dengan cara membandingkan data dari hasil observasi dengan hasil wawancara maupun dengan hasil studi dokumen.

\section{Dokumentasi}

Dokumentasi menurut Sugiyono merupakan pelengkap dari penggunaan metode wawancara dan metode observasi dalam penelitian 
kualitatif. ${ }^{90}$ Metode wawancara merupakan metode yang tidak terlalu sulit, karena bila terjadi kekeliruan maka sumber yang kita jadikan rujukan dalam penelitian masih bisa dibuka dan direvisi lagi. Data dari hasil dokumentasi ini digunakan untuk melengkapi data yang diperoleh oleh dokumentasi kegiatan pembelajaran siswa Sekolah Dasar Luar Biasa Tunarungu Negeri Tulungagung, selain dokumen tersebut masih ada dokumen penunjang lain seperti profil sekolah, dan peraturan-peraturan tertulis yang ada di Sekolah Dasar Luar Biasa Tunarungu Negeri Tulungagung.

Tabel 3.1 Dokumentasi yang diperlukan

\begin{tabular}{|l|l|}
\hline No & \multicolumn{1}{|c|}{ Jenis Dokumentasi } \\
\hline 1 & $\begin{array}{l}\text { Data Siswa } \\
\text { a. Jumalah ruangan, jumlah siswa } \\
\text { b. Dokumen biodata siswa } \\
\text { c. Laporan nilai siswa dari berbagai aspek }\end{array}$ \\
\hline 2 & $\begin{array}{l}\text { Saran prasarana } \\
\text { a. Denah lokasi dan bangunan sekolah } \\
\text { b. Gedung dan ruangan yang ada } \\
\text { c. Fasilitas (perpustakaan, laboratorium dan sebagainya) } \\
\text { d. Sarana pendidikan lainnya }\end{array}$ \\
\hline 3 & $\begin{array}{l}\text { Data ketenagaan } \\
\text { a. Kepala Sekolah Dasar Luar Biasa B Negeri Tulungagung } \\
\text { b. Guru Sekolah Dasar Luar Biasa B Negeri Tulungagung } \\
\text { c. Karyawan Sekolah Dasar Luar Biasa B Negeri Tulungagung }\end{array}$ \\
\hline 4 & $\begin{array}{l}\text { Proses belajar mengajar } \\
\text { a. Jadwal pelajaran dan Jadwal ekstrakurikuler } \\
\text { b. Tata tertib siswa }\end{array}$ \\
\hline 5 & $\begin{array}{l}\text { Sejarah sekolah } \\
\text { a. Sejarah dan berkembangnya Sekolah Dasar Luar Biasa B } \\
\text { Negeri Tulungagung } \\
\text { b. Visi, misi dan tujuan Sekolah Dasar Luar Biasa B Negeri } \\
\text { Tulungagung dan struktur organisasi sekolah. }\end{array}$ \\
\hline
\end{tabular}

${ }^{90}$ Sugiyono, Metode Penelitian Kuantitatif, Kualitatif dan $R \& B$..., hal. 240. 
Keterkaitan pertanyaan peneliti, sumber data dan pengumpulan data dijelaskan dalam bentuk tabel sebagai berikut.

Tabel 3.2 Keterkaitan Data, Sumber Data dan Pengumpulan Data

\begin{tabular}{|c|c|c|c|c|}
\hline No & Data & $\begin{array}{l}\text { Sumber } \\
\text { data }\end{array}$ & $\begin{array}{c}\text { Teknik } \\
\text { Pengumpulan } \\
\text { Data }\end{array}$ & $\begin{array}{c}\text { Rambu-Rambu yang } \\
\text { Dibutuhkan }\end{array}$ \\
\hline \multirow[t]{3}{*}{1} & \multirow[t]{3}{*}{$\begin{array}{l}\text { Strategi guru } \\
\text { dalam } \\
\text { pembentukan } \\
\text { karakter } \\
\text { kemandirian } \\
\text { belajar pada } \\
\text { siswa } \\
\text { berkebutuhan } \\
\text { khusus tuna } \\
\text { rungu }\end{array}$} & Guru & Wawancara & $\begin{array}{l}\text { 1. Pedoman penyusunan } \\
\text { silabus, RPP, media } \\
\text { pembelajaran, buku ajar } \\
\text { 2. Tahapan proses } \\
\text { Penyusunan silabus, } \\
\text { RPP, media } \\
\text { pembelajaran, buku ajar } \\
\text { 3. Strategi pengelolaan } \\
\text { Kelas }\end{array}$ \\
\hline & & $\begin{array}{l}\text { Kepala } \\
\text { sekolah }\end{array}$ & Wawancara & $\begin{array}{l}\text { 1. Strategi pembelajarana } \\
\text { 2. Strategi pengelolaan } \\
\text { Kelas } \\
\text { 3. Penyusunan ulang } \\
\text { kurikulum }\end{array}$ \\
\hline & & $\begin{array}{l}\text { Dokumen } \\
\text { Naskah } \\
\text { pembelaja } \\
\text { ran }\end{array}$ & Dokumentasi & $\begin{array}{l}\text { 1. Sumber belajar yang } \\
\text { digunakan } \\
\text { 2. Laporan hasil nilai } \\
\text { siswa dari berbagai } \\
\text { aspek (kognitif, afektif } \\
\text { dan psikomotorik) }\end{array}$ \\
\hline 2 & $\begin{array}{l}\text { Pelaksanaan } \\
\text { strategi guru } \\
\text { dalam } \\
\text { pembentukan } \\
\text { karakter } \\
\text { kemandirian } \\
\text { belajar pada } \\
\text { siswaABK }\end{array}$ & Guru & Observasi & $\begin{array}{l}\text { 1. Pelaksanaan } \\
\text { pembelajaran } \\
\text { 2. Faktor pendukung } \\
\text { pelaksanaan } \\
\text { pembelajaran }\end{array}$ \\
\hline
\end{tabular}




\begin{tabular}{|l|l|l|l|l|}
\hline No & \multicolumn{1}{|c|}{ Data } & $\begin{array}{c}\text { Sumber } \\
\text { data }\end{array}$ & $\begin{array}{c}\text { Teknik } \\
\text { Pengumpulan } \\
\text { Data }\end{array}$ & \multicolumn{1}{c|}{$\begin{array}{c}\text { Rambu-Rambu yang } \\
\text { Dibutuhkan }\end{array}$} \\
\hline 3 & $\begin{array}{l}\text { Dampak dalam } \\
\text { pembentukan } \\
\text { karakter } \\
\text { kemandirian } \\
\text { belajar pada } \\
\text { siswa }\end{array}$ & Guru & Wawancara & $\begin{array}{l}\text { 1. Faktor pendukung } \\
\text { pelaksaan pembelajaran }\end{array}$ \\
& & & $\begin{array}{l}\text { 2. Dampak pembentukan } \\
\text { karakter kemandirian } \\
\text { belajar pada siswa }\end{array}$ \\
\hline
\end{tabular}

\section{F. Analisis Data}

Analisis data dalam penelitian ini menggunakan tiga langkah analisis yang disarankan Miles dan Huberman yaitu reduksi data, pemaparan bahan empiris dan penarikan kesimpulan dan verifikasi. Analisis data dijelaskan sebagai berikut.

1. Pengelompokan Data

Pengelompokan data dilakukan untuk mempermudah dalam menganalisis data yang telah terkumpul. Pengelompokan data dilakukan berdasarkan pada rumusan-rumusan masalah dalam penelitian. Hasil pengelompokan data merupakan kumpulan data penelitian yang merupakan data hasil dari wawancara, hasil observasi dan hasil analisis dokumen.

2. Reduksi Data

Reduksi data merupakan penyederhanaan data. Penyederhanaan data dilakukan jika hasil pengelompokan data ditemukan data yang sejenis atau data yang bermakna sama. Data yang sama atau sejenis direduksi sehingga menjadi data tunggal. Penyederhanaan data dilakukan untuk mempermudah dalam menjawab rumusan masalah penelitian. 


\section{Penarikan Kesimpulan dan Verifikasi}

Hasil dari reduksi data dijadikan dasar dalam membuat atau menarik kesimpulan penelitian. Kesimpulan penelitian merupakan jawaban dari rumusan masalah dalam penelitian. Kesimpulan penelitian untuk selanjutnya akan diuji keabsahan menggunakan teknik member check.

\section{G. Uji Keabsahan Data}

Untuk menguji keabsahan data pada penelitian ini menggunakan triangulasi dan cek member.

1. Triangulasi

Triangulasi yaitu membandingkan data penelitian. Triangulasi yang digunakan dalam penelitian ini diklasifikasikan sebagai berikut.

a. Triangulasi Sumber

Triangulasi sumber merupakan cara membandingkan data primer yaitu membandingkan data antar informan. Triangulasi sumber dalam penelitian ini berarti membandingkan data hasil wawancara antar guru dokumen. Trianggulasi sumber dilakuakan dengan cara membandingkan hasil wawancara antara guru kelas dan kelapa sekolah.

b. Triangulasi Metode

Triangulasi metode merupakan cara membandingkan data antar metode. Triangulasi metode dilakukan melalui membandingkan data hasil wawancara dengan data hasil observasi, membandingkan data hasil observasi dengan data hasil analisis 
dokumen dan membandingkan data hasil wawancara dengan data hasil analisis dokumen.

\section{Member Checking}

Menurut Sutopo member checking yaitu melakukan pengecekan terhadap keabsahan data dengan mengkonfirmasikan hasil penelitian kepada sumber data. ${ }^{91}$ Member check dilakukan untuk mendapat persetujuan dan persamaan pemahaman antara peneliti dengan informan yaitu guru di SDLB Negeri Tulungagung.

\section{H. Prosedur Penelitian}
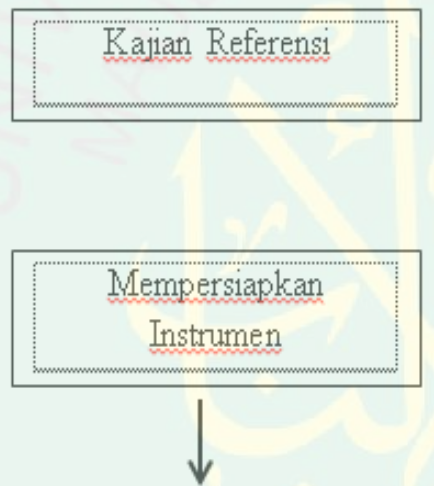

Pengumpulan data

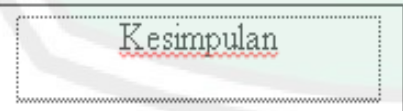

$\downarrow$

Penyusunan Laporan

Penelitian
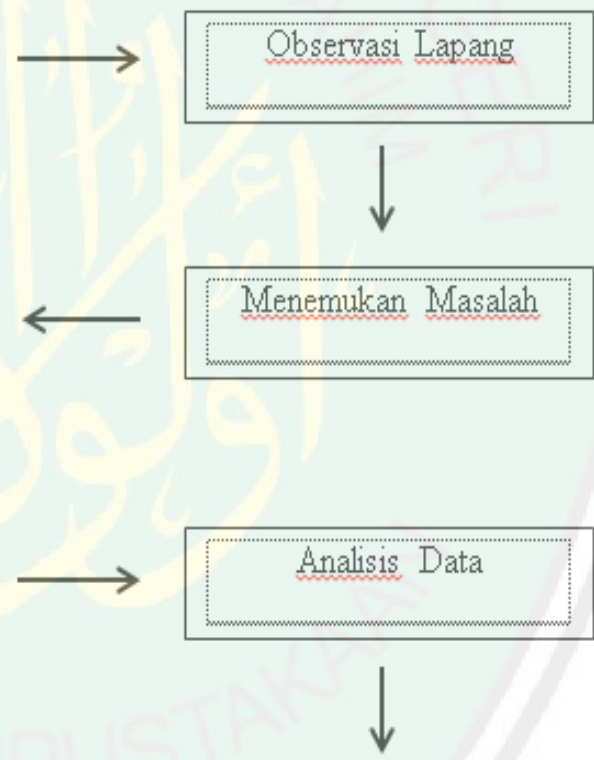

Uj1 Keabsahan Data

Gambar 3.1 Prosedur Penelitian

${ }^{91}$ Sutopo, Metodologi Penelitian Kualitatif, (Surakarta: UNS, 2006), hlm. 92. 
Prosedur dalam penelitian ini terdiri dari tiga tahapan yaitu tahap awal, tahap pelaksanaan dan tahap akhir. Prosedur penelitian dijelaskan sebagai berikut.

\section{Identifikasi Masalah}

Identifikasi masalah menggunakan kajian literatur. Identifikasi masalah dilakukan untuk menemukan masalah penelitian. Masalah penelitian yaitu kesenjangan (gap) antara harapan dan kenyataan. Hasil dari identifikasi masalah dilakukan obsevasi lapang.

2. Observasi lapang

Observasi lapang dimaksudnya untuk mendapatkan fakta empiris. Observasi lapang dilakukan sebagai studi pendahuluan dalam penelitian untuk mendapatkan korelasi dan relevansi antara kajian literatur dengan pengalaman nyata.

3. Penyusunan Instrumen Penelitian

Instrumen penelitian merupakan alat untuk pengumpulan data di lapangan. Instrumen penelitian berupa angket, lembar wawancara, lembar observasi dan lembar identifikasi dokumen.

4. Pengumpulan Data

Pengumpulan data di lapangan menggunakan instrumen yang telah disusun. Instrumen penelitian dalam penelitian ini mengunakan angket, lembar wawancara, lembar observasi dan lembar identifikasi dokumen.

5. Analisis Data

Analisis data kualitatif dilakukan melalui tahapan yaitu 
pengelompokan data, reduksi data, verifikasi dan penarikan kesimpulan.

\section{Uji Keabsahan Data}

Uji keabsahan data kualitatif dilakukan melalui triangulasi data dan member check.

7. Membuat Kesimpulan Penelitian

Kesimpulan penelitian dibuat berdasarkan rumusan masalah penelitian. Kesimpulan penelitian merupakan jawaban dari rumusan masalah penelitian.

8. Penyusunan Laporan Penelitian

Laporan penelitian disusun sebagai bentuk pertanggung jawaban keilmuan. Laporan penelitian dimanfaatkan untuk membatu menyelesaikan masalah di tempat penelitian maupun diterbitkan secara umum di jurnal penelitian. 


\section{BAB IV}

\section{PAPARAN DATA DAN HASIL PENELITIAN}

\section{A. Paparan Data}

\section{Gambaran Umum Lokasi Sekolah Dasar Luar Biasa}

Sekolah Dasar Negeri Luar Biasa bagian B atau Tunarungu ini terletak di Jalan Pangeran Diponegoro V/2 Tamanan Kecamatan Tulungagung Kabupaten Tulungagung, dibangun dengan gotong royong swada oleh masyarakat pada tahun 1984 M dengan status tanah wakaf. Pada tahun 1990 sekolah ini beralih status sekolah dasar luar biasa Negeri, sekolah ini terletak di kota Tulungagung sehingga mudah dijangkau. Sekolah Dasar Luar Biasa ini memiliki tanah seluas 2,542 M dengan batas timur rumah masyarakat sebelah barat toko cat sebelah, sebelah utara jalan raya dan sebelah selatan rumah masyarakat.

Sekolah Dasar Negeri Luar Biasa Tunarungu Negeri Tulungagung ini melaksanakan proses belajar mengajarnya setiap hari senin sampai kamis, untuk hari jumat nya digunakan untuk melakukan kegiatan ekstrakurikuler, kelas I sampai kelas III mengikuti ekstrakurikuler mengambar, mewarnai dan melukis, untuk kelas IV sampai VI mengikuti ekstrakurikuler tataboga (memasak, menganyam, potong rambut). Hari sabtu dan minggu anak-anak libur. Proses belajar mengajarnya semua dimulai dari pukul 07.30 WIB, untuk kelas I dan II pulang pukul 11.00 WIB, kelas III pulang pukul 11.30 WIB, dan kelas IV sampai VI pulang pukul 12.00 WIB. 


\section{Visi, Misi dan Tujuan Sekolah}

Visi

Mendidik siswa bisa mandiri, berkemampuan optimal dan berakhlak mulia.

Misi

a. Melaksanakan kegiatan belajar mengajar mengacu pada perundangundangan yang berlaku.

b. Melaksanakan program kurikulum yang berlaku.

c. Menambahkan kegiatan ketrampilan.

d. Menambah bimbingan agama.

Tujuan Sekolah

a. Menampung anak berkebutuhan khusus (anak luar biasa/penyandang ketunaan) di daerah Tulungagung dan sekitarnya dalam lembaga pendidikan formal.

b. Mengembangkan potensi anak didik untuk menghadapi masa depan mereka yang kompetitif.

c. Memberikan pelayanan pendidikan secara utuh dan berkesinambungan.

\section{Jumlah Guru dan Tenaga Administrasi}

Pada tahun 2018/2019 jumlah guru dan tenaga kependidikan di Sekolah Dasar Luar Biasa Tunarungu Negeri Tulungagung 11 orang, yang terdiri dari 1 kepala sekolah dan 1 orang petugas perpus. Dari keseluruhan jumlah guru tersebut dengan guru status tetap/pegawai negeri sipil berjumlah 4 orang dengan 2 orang laki-laki dan 2 orang perempuan, guru honorer 3 orang laki-laki dan 2 orang perempuan, serta 1 orang perempuan 
petugas perpustakaan dan 1 orang laki-laki penjaga sekolah.

Ditinjau dari latar belakang pendidikannya guru dan tenaga kependidikan di Sekolah Dasar Luar Biasa Tunarungu Negeri Tulungagung mayoritas lulusan Strata 1 (S1), dengan jumlah 10 orang tamatan Strata 1 dan 1 orang penjaga sekolah lulusan Madrasah Aliyah.

Tabel 4.1

\begin{tabular}{|c|c|c|}
\hline \multicolumn{3}{|c|}{ Jabatan guru } \\
\hline Negeri & Honorer & Jumlah \\
\hline 4 & 7 & 11 \\
\hline
\end{tabular}

Dari jumlah keseluruhan guru yang ada di Sekolah Dasar Luar

Biasa Tunarungu Negeri Tulungagung ini harus sudah memiliki ijazah strata 1, dikarenakan untuk memenuhi persyaratan menjadi guru, selain itu dengan lulusan strata 1 diharapkan bisa menjadikan siswa-siswinya menjadi anak-anak yang berprestasi serta berakhlak.

\section{Jumlah Peserta Didik dan Jumlah Kelas}

Tercatat pada tahun 208/2019 Sekolah Dasar Luar Biasa Tunarungu Negeri Tulungagung mempunyai siswa sebanyak 35 siswa dengan jumlah siswa laki-laki 18 orang dan 17 orang perempuan dari jumlah keseluruhan ini terbagi dari kelas I sampai dengan kelas IV. Kelas I berjumlah 6 orang yang terdiri dari 3 orang laki-laki dan 3 orang perempuan, kelas II berjumlah 7 orang 3 orang laki-laki dan 4 orang perempuan, kelas III berjumlah 6 orang 4 orang laki-laki dan 2 orang perempuan, kelas IV berjumlah 6 orang 2 orang laki-laki dan 4 orang perempuan, kelas $\mathrm{V}$ berjumlah 6 orang 4 orang laki-laki dan 2 orang 
perempuan, kelas VI berjumlah 4 orang 2 orang laki-laki dan 2 orang perempuan, keseluruhannya terdiri dari 6 ruang belajar.

Tabel 4.2

\begin{tabular}{|c|c|c|c|}
\hline Kelas & Laki-laki & Perempuan & Jumlah \\
\hline I & 3 & 3 & 6 \\
II & 3 & 4 & 7 \\
III & 4 & 2 & 6 \\
IV & 2 & 4 & 6 \\
V & 4 & 2 & 6 \\
VI & 2 & 2 & 4 \\
\hline mlah & 18 & 17 & 35 \\
\hline
\end{tabular}

Dokumentasi Sekolah Dasar Luar Biasa Tunarungu Negeri Tulungagung

Dari keseluruhan jumlah siswa diatas bisa dilihat setiap kelas jumlah siswa tidak ada yang lebih dari 7, dikarenakan untuk sekolah luar biasa ada batas maksimal siswa yang mana setiap kelas tidak boleh lebih dari 7 orang, batas maksimal itu sesuai dengan pasal 24 Permendikbud nomor 17 tahun 2017 yang menyatakan batas maksimal dalam SDLB tidak lebih dari 7 siswa.

\section{Sarana dan Prasarana}

Untuk mewujudkan visi misi Sekolah Dasar Luar Biasa Tunarungu Negeri Tulungagung mempunyai sarana dan prasarana:

a. Gedung dan ruang belajar meliputi 6 rombongan belajar dan 1 perpustakaan.

b. Ruang kantor diisi ruang kepala sekolah dan ruang guru.

c. Ruang penunjang meliputi 1 aula dan 2 kamar mandi.

d. Lapangan untuk olahraga dan upacara. 
Tabel 4.3

Sarana dan Prasarana

\begin{tabular}{|c|c|c|c|c|}
\hline \multirow[t]{2}{*}{ No } & \multicolumn{4}{|c|}{ Sarana } \\
\hline & Nama Barang & Banyaknya & Rusak Ringan & Rusak Berat \\
\hline & $\begin{array}{l}\text { ja siswa } \\
\text { rsi siswa } \\
\text { ja guru } \\
\text { rsi guru } \\
\text { mari } \\
\text { k } \\
\text { pan tulis } \\
\text { pan pengumuman } \\
\text { pan data kelas } \\
\text { pe recorder } \\
\text { mputer } \\
\text { nter } \\
\text { D }\end{array}$ & $\begin{array}{c}37 \\
35 \\
6 \\
6 \\
6 \\
6 \\
6 \\
1 \\
6 \\
1 \\
1 \\
1 \\
1 \\
1\end{array}$ & $\begin{array}{l}- \\
- \\
- \\
- \\
- \\
- \\
- \\
- \\
- \\
- \\
- \\
- \\
- \\
-\end{array}$ & $\begin{array}{l}2 \\
- \\
- \\
- \\
- \\
- \\
- \\
- \\
- \\
- \\
- \\
- \\
- \\
-\end{array}$ \\
\hline
\end{tabular}

Dokumentasi Sekolah Dasar Luar Biasa Tunarungu Negeri Tulungagung

Menurut paparan data diatas untuk sarana dan prasarana di Sekolah

Dasar Luar Biasa Tunarungu Negeri Tulungagung masih belum lengkap, untuk sarana olahraga belum memadai.

\section{B. Hasil Penelitian}

Berdasarkan hasil penelitian di Sekolah Dasar Luar Biasa B Negeri Tulungagung, maka diperoleh data-data yang mengacu pada fokus penelitian.

Pengumpulan data-data ini mengunakan observasi, wawancara dan dokumentasi. Adapun poin-poin yang menjadi fokus penelitian sebagai berikut: 


\section{Strategi guru dalam membentuk karakter kemandirian belajar siswa}

berkebutuhan khusus melalui metode pembiasaan di Sekolah Dasar

\section{Luar Biasa Tunarungu Negeri Tulungagung.}

Peran guru pembelajaran dalam proses pembentukan karakter yang di miliki oleh para siswa sangat penting, peran ini harus di dukung oleh kemampuan para guru- guru yang berada di lingkungan sekolah dasar luar biasa tersebut, melalui metode pembiasaan guru dapat memberikan pembelajaran yang bermakna pada siswa sehingga siswa diharapkan mampu melakukan pembiasaan yang positif.

Sekolah luar biasa adalah sekolah di mana siswa-siswinya mempunyai kebutuhan khusus yang berbeda dengan siswa-siswi normal lainnya. Di sekolah ini juga mempunyai cara khusus untuk proses pembelajarannya, dan pada umumnya proses penyampaian pembelajarannya juga lebih sulit dibandingkan dengan sekolah normal.

Hasil observasi yang dilakukan peneliti kepada Kepala Sekolah yaitu tentang kegiatan rutin sebelum memulai pelajaran dan sebelum pulang dari sekolah yakni anak-anak harus bersalaman dengan para guru dan mengucapkan assalamualaikum yang keras, peneliti mengamati kegiatan tersebut memang rutin dilaksankan di Sekolah Dasar Luar Biasa Tunarungu Negeri Tulungagung, bentuk dari pembiasaan kemandirian siswa yaitu anak-anak dengan sendirinya bisa melakukan kegiatan itu secara rutin tanpa diberitahu dan tanpa paksaan dari orang lain. 
Hasil observasi peneliti menunjukkan kegiatan awal siswa setelah masuk tidak langsung memulai pelajaran melainkan berdoa dulu, untuk kegiatan berdoa anak-anak tunarungu mempunyai caranya sendiri yang pastinya berbeda dengan anak normal lainnya, setelah berdoa dilanjutkan anak-anak maju satu persatu ke depan untuk mengucapkan "assalamualaikum" dengan keras kepada teman-temannya.

Menurut Ibu Dra. Yayuk Triani selaku wakil kurikulum di Sekolah Dasar Luar Biasa B Negeri Tulungagung menuturkan upaya untuk membentuk karakter kemandirian siswa sekolah luar biasa diantaranya yaitu:

Untuk membentuk karakter kemandirian siswa luar biasa dengan melakukan banyak hal mulai dari yang ringan ataupun hal yang sepele, dikarenakan anak yang berkebutuhan khusus khususnya disini siswa tunarungu masih sulit untuk melakukan sesuatu dengan sendiri, masih banyak yang kurang percaya diri dengan keadaannya. Strategi yang digunakannya pun lebih ektra dibandingkan dengan yang biasa, disini guru wali kelas diberikan kebijakan sendiri untuk membentuk karakter kemandirian siswa sebagaimana memulainya dengan melakukan hal-hal kecil. Untuk kelas I masih mengalami kesulitan dalam melakukan kegiatan belajar mengajar dimana kelas I masih berada dalam tahap peralihan dari taman kanak-kanak. Di sini anak-anak tetap diberikan kegitan yang sama dengan anak normal pada sekolah umum lainnya, akan tetapi dengan ketentuan yang sesuai dengan anak. $^{92}$

Hasil obesrvasi yang dilakukan di Sekolah Dasar Luar Biasa

Tunarungu Negeri Tulungagung dalam strategi yang dilakukankan oleh guru yang berada di lingkungan sekolah tersebut dalam pembentukan karakter mandiri pada diri siswa yakni melalui metode pembiasaan, peneliti melihat dan mengamati proses yang di ajarkan oleh guru kepada

\footnotetext{
${ }^{92}$ Wawancara dengan Ibu Yayuk tanggal 09 Oktober 2018
} 
para peserta didik juga dikaitkan melalui pembelajaran tematik tema lingkungan pembelajaran IPA kelas IV, lingkungan ini dikaitkan dengan pelajaran PPKN bahwa setiap orang harus saling tolong menolong tidak boleh saling bermusuhan dan hidup rukun dengan temannya. ${ }^{93}$

Penelitian yang dilakukan pada Sekolah Dasar Luar Biasa Tunarungu Negeri Tulungagung dengan mengadakan wawancara tentang strategi dari guru Pembelajaran dalam pembentukan karakter kemandirian melalui metode pembiasaan pada siswa di Sekolah Dasar Luar Biasa Tunarungu Negeri Tulungagung. Berikut penuturan Ibu menjabat Sebagai wali kelas IV pada Sekolah Dasar Luar Biasa Tunarungu Negeri Tulungagung yang beliau ajarakan:

Dalam setiap kali proses pembelajara Saya selalu merangsang para peserta didik untuk berani tampil di depan kelas untuk mengerjakan soal-soal, disamping itu di luar kelas saya juga merangsang/memotivasi mereka untuk berani tampil di depan umum, khususnya pada kegiatan lomba-lomba yang di adakan oleh Dinas Tulungagung. Mengadakan acara perpisahan dengan kelas VI, pada acara tersebut para siswa yang kelas IV dan kelas $\mathrm{V}$ di berikan kesempatan untuk menyampaikan pesan dan kesan selama berada di sekolah menggunakan bahasa isyarat dan menggunakan bahasa tubuh. Membiasakan para siswa untuk meyapu ruangan belajar (Kelas), menata ruangan belajar agar bersih dan rapi yang diatur ketua kelas setiap hari. Membiasakan para siswa untuk membersihkan papan tulis sebelum memulai pelajaran dan setelah pembejaran berlangsung agar bersih untuk kegiatan belajar mata pelajaran berikutnya. Membiasakan para siswa membersihkan dalam dan luar kelas agar sekolah menjadi tempat yang nyaman untuk tempat menuntut ilmu, dan pembiasaan di sekolah ini akan di laksanakan di rumah para siswa. Saya juga membiasakan siswa melakukan kegiatannya sendiri, seperti jika waktu praktek keterampilan anak harus bisa melakukan kegiatan itu sendiri, untuk anak kelas IV ada target harus bisa melakukan sosialisasi dengan teman-teman yang berbeda dengan kelasnya, dengan cara setiap setengah jam

${ }^{93}$ Observasi di Sekolah Dasar Luar Biasa Tunarungu Negeri Tulungagung tanggal 11 Oktober 2018 
sebelum pulang sekolah anak kelas IV harus pergi ke kelas $\mathrm{V}$ dan VI, dengan bergantian satu persatu menyapa mereka dengan mengeluarkan suara keras. ${ }^{94}$

Selanjutnya ibu Tri Agus Winarni sebagai wali kelas I menuturkan strategi untuk membentuk karakter kemandirian belajar siswa sebagai berikut:

Anak kelas I atau kelas rendah masih sulit dikendalikan, di mana mereka masih berada ditahap peralihan dari sekolah taman kanakkanak (TK), disini saya selaku wali kelas selalu mengupayakan yang pertama agar anak-anak mau ditinggal orang tuanya, setelah itu saya melakukan pembiasaan dengan menyuruh anak-anak dirumah menyiapkan peralatan sekolahnya sendiri, setiap pagi saya bertanya kepada anak-anak siapa saja yang tadi pagi sebelum berangkat sekolah menyiapkan peralatannya sendiri, siapa saja yang sudah menyiapkan peralatannya sendiri saya kasih hadiah. Hal ini selain bisa membentuk karakter kemandirian siswa juga bisa membiasakan diri untuk berkata jujur. Dalam hal pembelajaran saya selalu mengaitkan tema dengan kegiatan sehari-hari, pada tema diriku saya mengaitkan dengan kegiatan merawat lingkungan dan merawat tubuh dengan cara menerapkan anak supaya membuang sampah (bungkus jajan dan sebagainya) pada tempatnya dan menyuruh anak-anak dirumah mandi sendiri tanpa bantuan orangtua, di dalam kelas anak dilatih untuk bisa menulis suatu kalimat yang ada di papan tulis. ${ }^{95}$

Bapak Ahsan selaku guru olahraga menuturkan karakter

kemandirian siswa di Sekolah Dasar Luar Biasa Tunarungu Negeri

Tulungagung antara lain:

Lebih khusus dibidang olahraga siswa di Sekolah Dasar Luar Biasa Tunarungu Negeri Tulungagung mereka mampu melakukan persiapan menyiapkan alat-alat untuk olahraga dan anak-anak mampu melakukan kegiatan olahraga dengan baik. ${ }^{96}$

\footnotetext{
${ }^{94}$ Wawancara dengan Ibu Puput tanggal 15 Oktober 2018

${ }^{95}$ Wawancara dengan Ibu Tri Agus Winarni tanggal 22 Oktober 2018

${ }^{96}$ Wawancara dengan bapak Ahsan tanggal 19 Oktober 2018
} 
Hal ini menunjukkan bahwa semua kegiatan yang dipaparkan oleh guru-guru mampu memupuk karakter-karakter siswa di Sekolah Dasar Luar Biasa Tunarungu Negeri Tulungagung, khususnya dalam hal karakter kemandirian siswa.

2. Strategi guru dalam pelaksanaan pembentukan karakter kemandirian belajar siswa berkebutuhan khusus melalui metode pembiasaan di Sekolah Dasar Luar Biasa Tunarungu Negeri Tulungagung •

Strategi merupakan cara yang dilakukan pihak sekolah khususnya guru yang berkecimpung di dalam ruang lingkup sekolah, untuk melaksanakan pembentukan karakter kemandirian belajar siswa yang sudah mulai terbentuk. Srtategi guru yang dilakukan diantaranya yaitu dengan cara setiap harinya selalu memeriksa kebiasan anak yang bertujuan untuk mengetahui sejauh mana kemandirian anak sudah terbentuk.

Hasil observasi peneliti dari strategi yang dilakukan oleh guru dalam pelaksanan pembentukan karakter kemandirian belajar siswa melalui metode pembiasaan diapresiasikan oleh kepala sekolah dengan cara setiap bulannya mengadakan perlombaan antar kelas maupun antar siswa dalam kelas, untuk anak kelas I sampai III mengikuti lomba menggambar, mewarnai dan melukis, untuk anak kelas IV sampai VI mengikuti lomba menganyam, memasak dan potong rambut, hal ini dilakukan oleh kepala sekolah diharapkan anak-anak bisa mempunyai kemandirian dan bisa dijadikan bekal setelah lulus sekolah, mengingat 
mereka merupakan siswa khusus. ${ }^{97}$

Ibu Yayuk juga menuturkan bahwa pelaksanaan pembentukan karakter mandiri siswa di Sekolah Dasar Luar Biasa melalui metode pembiasaan di SDLB Tunarungu Negeri Tulungagung adalah:

Proses dalam pelaksanaan pembentukan karakter kemandirian siswa di Sekolah Dasar Luar Biasa melalui metode pembiasaan di SDLB Tunarungu Negeri Tulungagung dengan mengadakan lomba-lomba diantara lomba menganyam dan memasak yang diikuti kelas IV sampai kelas VI, sedangkan untuk kelas I sampai III mengikuti lomba mewarnai dan melukis, lomba ini dilakukan setiap bulan sekali diharapkan siswa lebih bisa aktif serta mampu melakukan kegiatan itu secara mandiri. ${ }^{98}$

Dari penyataan bapak Kepala Sekolah dan wakil kurikulum diatas tentang strategi yang dilakukan untuk pelaksanaan pembentukan karakter mandiri para siswa, temuan ini di kuatkan oleh hasil observasi yang peneliti lakukan sebagaimana yang tertulis dalam catatan observasi berikut ini:

Peneliti berada di Sekolah Dasar Luar Biasa Tunarungu Negeri Tulungagung ini, peneliti melihat langsung kegiatan-kegiatan di Sekolah Dasar Luar Biasa Tunarungu Negeri Tulungagung ini antara lain lomba menganyam yang diikuti oleh anak kelas IV samapai VI, dimana lomba ini dilakukan untuk menumbuhkan mengetahui sejauh mana kemandirian siswa dan bisa dijadikan bekal setelah lulus sekolah. ${ }^{99}$

\footnotetext{
${ }^{97}$ Hasil observasi di Sekolah Dasar Luar Biasa Tunarungu Negeri tanggal 08 Oktober 2018

${ }^{98}$ Wawancara dengan Ibu Yayuk tanggal 09 Oktober 2018

${ }^{99}$ Observasi di Sekolah Dasar Luar Biasa Tunarungu Negeri Tulungagung tanggal 10 Oktober 2018
} 
3. Dampak pembentukan karakter kemandirian belajar siswa berkebutuhan khusus melalui metode pembiasaan di Sekolah Dasar Luar Biasa Tunarungu B Negeri Tulungagung.

Para siswa umumnya memiliki karakter-karakter yang berbedabeda begitu juga dengan siswa di sekolah dasar luar biasa ini dari karakter tersebut guru harus mampu memahami keadaan dan posisi mereka, melalui metode pembiasaan ini guru akan lebih mengetahui kemampuan-kemampuan para siswanya, lewat kebernian dan kemandirian yang ditunjukkan oleh para siswa dalam proses belajar mengajar berlangsung. Begitu juga dengan dampak yang dihasilkan dari siswa berbeda-beda.

Dalam membentuk karakter kemandirian yang dimiliki siswa di Sekolah Dasar Luar Biasa Tunarungu Negeri Tulungagung Bapak Sudarminto selaku kepala sekolah menuturkan bahwa dampak pembentukan karakter kemandirian siswa di Sekolah Dasar Luar Biasa melalui metode pembiasaan di SDLB Tunarungu Negeri Tulungagung antara lain:

Kemandirian para siswa di Sekolah Dasar Luar Biasa Tunarungu Negeri Tulungagung ditunjukkan saat kegiatan proses belajar misalnya saat pelajaran muatan lokal siswa mampu menyiapkan bahan-bahan untuk kegiatan memasak, karena mereka dari awal sudah dibiasaakan melakukan hal tersebut, untuk kelas rendah sudah mau melakukan aktifitasnya sendiri, dimana setiap kegiatan kecil yang positif merupakan sesuatu yang sangat baik, namun masih ada dampak negatifnya diantaranya siswa kelas I yang kurang aktif tetap tidak mau berkembang, dimana anak kelas I merupakan peralihan dari taman kanak-kanak yang notabennya masih suka bermain, untuk siswa kelas IV biasanya masih ada yang bermalas-malasan, dan susah dikendalikan. ${ }^{100}$

${ }^{100}$ Wawancara dengan bapak Sudarminto tanggal 08 Oktober 2018 
Temuan ini dikuatkan oleh hasil observasi yang peneliti lakukan sebagaimana yang tertulis dalam catatan observasi peneliti bahwa di kelas IV siswanya sudah mampu mandiri melakukan tugasnya dengan baik, dimana peneliti ikut masuk di kelas IV dan mengamati proses kegiatan belajar siswa kelas IV. Siswa kelas IV mampu mengerjakan setiap soal-soal yang diberikan oleh guru, mereka juga mampu mempraktekkan apa yang tadi diajarkan oleh guru, namun seperti yang dituturkan bapak kepala sekolah masih ada anak yang malas belajar. ${ }^{101}$

Ibu Puput menuturkan bahwa dampak dari pembentukan karakter kemandirian belajar siswa melalui metode pembiasaan diantaranya yaitu:

Sejauh ini masih ada dampak negatifnya, diantaranya anak yang IQ nya rendah masih mengalami kesulitan dalam melakukan aktifitasnya sendiri, dimana saya sendiri basic nya bukan pendidik SLB jadi untuk menangani anak yang IQ rendah masih mengalami kesulitan, dampak bagi anak yang seperti itu dia masih tetap ditempat dan sulit diajak berkembang. ${ }^{10}$

Ibu Tri Agus Winarni sebagai wali kelas I menuturkan bahwa siswa di Sekolah Dasar Luar Biasa Tunarungu Negeri Tulungagung yaitu:

Siswa kelas I di Sekolah Dasar Luar Biasa Tunarungu Negeri Tulungagung sudah mulai mampu mengerjakan soal-soal mudah dan mau mengerjakan soal yang diberikan guru dan mulai mau menyiapkan alat tulisnya sendiri. Namun untuk anak yang masih ditunggu orangtuanya mempunyai kelambatan dalam mengikuti pembelajaran, anak yang masih ditungguin orang tuanya cenderung manja, untuk menghadapi anak tersebut butuh waktu pembiasaan yang lama dan sangat lambat. ${ }^{103}$

${ }^{101}$ Observasi di Sekolah Dasar Luar Biasa Tunarungu Negeri Tulungagung tanggal 16 Oktober 2018

\footnotetext{
${ }^{102}$ Wawancara dengan Ibu Puput tanggal 16 Oktober 2018

${ }^{103}$ Wawancara dengan Ibu Tri tanggal 23 Oktober 2018
} 
Hal ini dikuatkan dengan hasil observasi yang peneliti lakukan di Sekolah Dasar Luar Biasa Tunarungu Negeri Tulungagung, peneliti ikut masuk di kelas I dan mengamati siswanya saat kegiatan belajar berlangsung, disini siswa sudah mau mengerjakan soal yang mudah tanpa dibantu guru dan teman, meskipun masih ada dua siswa yang malas untuk menyelesaikan soal dan masih minta ditemani orangtuanya. ${ }^{104}$

Temuan ini dikuatkan oleh hasil observasi yang dilakukan peneliti sebagaimana tertulis dalam catatan observasi bahwa siswa di Sekolah Dasar Luar Biasa Tunarungu Negeri Tulungagung mengikuti olahraga dengan tertib. ${ }^{105}$ Untuk anak kelas I dalam hal olahraga mereka sudah mampu mengikuti kegiatan olahraga sederhana diantaranya lempar bola dan tangkap bola, lari mengitari halaman, hal itu merupakan hal yang sangat positif meskipun hanya sesuatu yang sederhana, namun pembentukan karakter kemandirian belajar siswa melalui metode pembiasaan pada kelas I terkadang masih mengalami kesulitan dimana kelas I anak- anak masih sulit diatur.

${ }^{104}$ Observasi di Sekolah Dasar Luar Biasa Tunarungu Negeri Tulungagung tanggal 22 Oktober 2018

${ }^{105}$ Observasi di Sekolah Dasar Luar Biasa Tunarungu Negeri Tulungagung tanggal 19 Oktober 2018 


\section{BAB V}

\section{PEMBAHASAN}

Bab ini bertujuan menganalisis data-data di lapangan yang telah berhasil dihimpun dan di paparkan sesuai data yang di harapkan dalam rumusan penelitian pada bab sebelumnya. Selanjutnya data-data tersebut akan dianalisis, baik data yang terkait dengan hasil observasi, dokumentasi serta wawancara, dari kesemuanya akan di diskusikan dengan berbagai referensi secara dialektik. Lebih kongkritnya, cara kerja analisis dalam penelitian ini akan menghubungkan antara data temuan dilapangan yang telah dihimpun oleh peneliti, di diskusikan dengan seperangkat teori-teori yang tersedia dalam kajian teori, di kaitkan latar penelitian, intrument penelitian, dan beberapa unit analisis lain yang terkait. Sesuai dengan jenisnya yaitu penelitian kualitatif, data-data temuan tersebut diharapkan menjadi pijakan sekaligus dasar bagi peneliti untuk membangun teori dalam penelitian ini.

Dalam Bab IV telah dipaparkan data dan hasil temuan di lapangan. Selanjutnya pada Bab ini, temuan-temuan pada Bab IV tersebut akan di bahas dan di analisis untuk merekonstruksi konsep yang didasarkan pada informasi empiris, adapun bagian-bagian yang akan di bahas pada bagian ini sesuai dengan fokus penelitian meliputi: 
A. Strategi Guru dalam Membentuk Karakter Kemandirian Belajar Siswa Berkebutuhan Khusus melalui metode pembiasaan di Sekolah Dasar Luar Biasa Tunarungu Negeri Tulungagung.

Pendidikan di sekolah seharusnya memang bukan sekedar memberikan berbagai macam pengetahuan terutama sekolah luar biasa, melainkan juga harus bisa membentuk karakter para siswanya. Membentuk karakter siswa tidaklah mudah dan serta merta diajarkan secara terpisah melaikan menjadi satu kesatuan dalam setiap tindak-tanduk siswa dan guruguru di madrasah.

Guru atau pendidik memiliki tanggung jawab besar dalam menghasilkan generasi yang berkarakter, berbudaya, dan bermoral. Guru merupakan teladan bagi siswa dan memiliki peran yang sangat besar dalam pembentukkan karakter siswa. Tugas-tugas manusiawi itu merupakan trasformasi, identifikasi, dan pengertian diri sendiri.Ketiga tugas guru itu harus dilaksanakan secara bersama-sama dalam kesatuan yang organis, harmonis, dan dinamis. Seorang guru tidak hanya mengajar dalam kelas, tetapi juga harus mampu katalisator, motivator, dan dinamisator pembangunan ditempat tinggalnya.

Tugas Guru adalah melahirkan potensi siswa ke permukaan dengan banyak berlatih, mengasah kemampuan, dan mengembangkan potensi semaksimal mungkin. Salah satu upaya yang efektif adalah dengan menyediakan wahana aktualisasi sebanyak mungkin, misalnya sering mengadakan lomba, pentas seni, dan lainnya. Semakin banyak praktik, 
semakin baik dalam upaya melahirkan dan mengembangkan potensi. ${ }^{106}$

Merujuk dari teori diatas berdasarkan hasil observasi dan wawancara bahwa proses terbentuknya karakter siswa melalui metode pembiasaan di Sekolah Dasar Luar Biasa Tunarungu Negeri Tulungagung ini peran utama seorang guru dalam memberikan motivasi kepada para siswasiswi ini sangat berpengaruh terhadap pembentukan karakter kemandian yang dimiliki oleh para siswa di Sekolah tersebut, disamping itu di Sekolah Dasar Luar Biasa Tunarungu Negeri Tulungagung juga selalu mengadakan kegiatan-kegiatan baik di dalam lingkungan sekolah maupun di luar lingkungan sekolah, seperti lomba-lomba yang dapat meningkatakan karakter kemandirian yang di miliki oleh para siswa.

Berdasarkan wawancara dengan informan dan observasi di sekolah, Proses terbentuknya karakter khususnya kemandirian pada siswa di Sekolah Dasar Luar Biasa Tunarungu Negeri Tulungagung guru-guru mendorong para siswa untuk berpatisipasi aktif dalam proses pembelajaran dalam kelas disamping itu guru juga memberikan kebebasan kepada para siswa untuk mengerjakan soal-soal yang di berikan kepada siswa dan di kerjakan di papan tulis. Kegiatan ini dapat mengembagkan proses kemandirian yang ada pada diri siswa dan juga menumbuhkan rasa keberanian para siswa untuk tampil di depan teman-temannya.

106 Jamal Ma'ruf Asmani, Buku Panduan Internalisasi Pendidikan Karakter disekolah Cet VI, (Yogjakarta: Diva Press, 2013), hal. 77. 


\section{Menurut Muhamad Afandi tentang Pendidikan Anak Berkebutuhan}

Khusus indikator kemandirian belajar pada ABK yaitu: ${ }^{107}$

1. Bertanggung jawab atas tugasnya.

2. Mampu mengerjakan tugasnya.

3. Mampu beradaptasi dengan lingkungan.

4. Percaya diri dalam melakukan suatu hal.

Dari keempat ciri-ciri prilaku untuk karakter kemandirian anak yang berkebutuhan khusus, dari observasi yang dilakukan oleh peneliti di Sekolah Dasar Luar Biasa Tunarungu Negeri Tulungagung anak-anak kelas I maupun kelas IV sudah mampu mengerjakan dan menjawab soal-soal yang diberikan oleh guru serta mampu melaksanakan perintah yang diberikan guru dan mampu mengerjakan pekerjaan rumah. Untuk kelas IV anak sudah mampu beradaptasi dengan teman- temannya serta bisa melakukan pembelajaran dengan baik. Sedangkan untuk penerapan metode pembiasaan kepada siswa juga sudah terlaksana, diantaranya siswa sudah terbiasa selalu mengucapkan salam sebelum masuk kelas dan mau keluar kelas, membersihkan papan tulis sebelum kegiatan pembelajaran berlangsung, membersihkan ruang kelas, untuk anak kelas I mereka sudah mau membuang sampah jajan pada tempatnya dan mau maju satu persatu untuk mengerjakan soal di depan teman-temannya. Dari pembiasaan-pembiasaan sederhana tersebut bisa menumbuhkan karakter kemandirian dari siswa tersebut.

${ }^{107}$ Muhamad Afandi dan Galuh, Pendidikan Anak Berkebutuhan Khusus ..., hal. 95. 


\section{B. Strategi Guru dalam Pelaksanaan Pembentukan Karakter Kemandirian}

Belajar Siswa Berkebutuhan Khusus melalui metode pembiasaan di Sekolah Dasar Luar Biasa Tunarungu Negeri Tulungagung •

Secara teoritis strategi dalam pembentukan karakter kemandirian belajar melalui metode pembiasaan pada siswa di Sekolah Dasar Luar Biasa Tunarungu Negeri Tulungagung mempunyai konsep keteladanan merupakan faktor mutlak yang harus dimiliki oleh kepala sekolah dan guru di Sekolah Dasar Luar Biasa Tunarungu Negeri Tulungagung. Dalam pendidikan karakter keteladanan dibutuhkan oleh guru berupa konsistensi dalam menjalankan perintah agama dan menjauhi larang-larangannya, kepedulian terhadap nasib orang-orang tidak mampu, kegigihan dalam meraih prestasi secara individu dan social, ketahanan dalam menghadapi tantangan, rintangan, dan godaan; serta kecepatan dalam bergerak dan beraktualisasi. Selain itu, dibutuhkan pula kecerdasan guru dalam membaca, memanfaatkan, dan mengembangkan peluang secara produktif dan kompetitif. Keteladanan guru sangat penting demi efektifitas pendidikan karakter. Tanpa keteladanan, pendidikan karakter kehilangan ruhnya yang paling esensial, banyak slogan, kamuflase, fatamorgana, dan kata-kata negatif lainnya. ${ }^{108}$

Berdasrkan wawancara dengan kepala Sekolah Dasar Luar Biasa Tunarungu Negeri Tulungagung salah satu kebijakan yang utama dalam pelaksanaan pembentukan karakter kemandirian siswa melalui metode

108 Jamal Ma'ruf Asmani, Buku Panduan Internalisasi Pendidikan Karakter di Sekolah $\ldots$, hal. 75 . 
pembiasaan di Sekolah adalah mengadakan lomba antar kelas maupun lomba siswa dalam kelas yang rutinistas diadakan sebulan sekali yang harus di laksanakan oleh seluruh siswa dalam sekolah, serta salah satu bentuk pengaplikasian dari kegiatan-kegiatan lomba yang di keluarkan oleh kepala sekolah salah satunya adalah konsep ketedaladan/contoh dari guru-guru dan pembiasaan di sekolah tersebut yang dapat di ikuti oleh para siswa sehingga bisa dilaksanakan secara rutin dan dapat menjadi kebiasaan bagi para siswa sehingga dapat menumbuhkan karakter kemandirian para siswa yang telah ada pada diri siswa di Sekolah tersebut.

Strategi seorang pemimpin pada lembaga-lembaga pendidikan sering kali menjadi titik perhatian para ahli, baik dibidang ilmu pendidikan atau dibidang ilmu lainnya. Dalam ini berkaitan dengan kebijakan kepala sekolah sebagai penanggung jawab eksistensi atau keberadaan sebuah lembaga pendidikan.

Satu unsur penting dari proses kependidikan adalah pendidik. Di pundak pendidik terletak tanggung jawab yang amat besar dalam upaya mengantarkan peserta didik kearah tujuan pendidikan yang dicita-citakan. Hal ini disebabkan pendidikan merupakan cultural transition yang bersifat dinamis ke arah suatu perubahan secara continue, sebagai sarana vital dalam membangun kebudayaan dan peradaban umat manusia. Dalam hal ini, pendidik bertanggung jawab memenuhi kebutuhan peserta didik, baik spiritual, intelektual, moral, estetika, maupun kebutuhan pisik siswa. ${ }^{109}$

${ }^{109}$ Samsul Nizar, Pendidikan Filsafat Islam, (Jakarta: Ciputat Press, 2000), hal. 41. 
Berdasarkan temuan lapangan hasil observasi peneliti terhadap kepala Sekolah Dasar Luar Biasa Tunarungu Negeri Tulungagung, strategi kepala sekolah sangat efektif untuk pelaksanaan pembentukan karakter kemandirian siswa dari konsep keteladanan dan pembiasaan positif dari kepala sekolah, serta guru- guru yang berada dalam sekolah tersebut sehingga membentuk kemandirian siswa diantaranya siswa berdoa bersama sebelum memulai pelajaran yang dipimpin oleh satu orang di depan kelas setelah itu maju satu persatu mengucapkan assalamualaikum dengan keras dan kegiatan ini dijadikan rutinitas oleh guru dan para siswa di Sekolah Dasar Luar Biasa Tunarungu Negeri Tulungagung.

Pendidikan bukan merupakan sarana transfer ilmu pengetahuan saja, melainkan lebih luas lagi yakni sebagai sarana pemberdayaan dan penyaluran nilai engkulturasi dan sosialisasi. Anak harus mendapatkan pendidikan yang menyentuh dimensi dasar kemanusiaan itu mencakup sekurang-kurangnya tiga hal paling penting yaitu Afektif yang tercermin pada kwalitas keimanan, ketakwaan dan akhlak mulia, termasuk budi pekerti luhur serta kepribadian unggul, dan kompetensi estetis, Kognitif yang tercermin pada kapasitas pikir dan daya intlektual untuk menggali dan mengembangkan serta menguasi ilmu pengetahuan dan tekhnologi. Psikomotorik yang tercermin pada kemampuan mengembangkan keterampilan teknis, kecakapan praktis, dan kompetensi kinestetis. ${ }^{110}$

${ }^{110}$ Barnawi dan M Arifin, Pendidikan Karakter Strategi dan Kebijakan Pembelajaran, (Jogjakarta: Ar Ruzz Media, 2012), hal. 30. 
Sejalan dengan pendapat informan dalam wawancara disamping dari aspek afektif dan psikomotorik dalam pelaksanaan pembentukan karakter para peserta didik, akan tetapi aspek kognitif sangat utama dalam mengembangkan karakter para siswa dengan demikian siswa berani mengucapkan salam ketika pulang ke rumah maupun bertemu dengan masyarakat di lingkungan mereka tinggal.

Manfaat penerapan metode pembiasaan dalam pembentukan karakter kemandirian belajar siswa sangat berperan penting dimana dengan adanya pembiasaan yang positif bisa menciptakan karakter kemandirian pada siswa. Dari manfaat tersebut para siswa di Sekolah Dasar Luar Biasa Tunarungu Negeri Tulungagung bisa memiliki karakter kemandirian yang positif.

C. Dampak Pembentukan Karakter Kemandirian Belajar Siswa Berkebutuhan Khusus melalui metode pembiasaan di Sekolah Dasar Luar Biasa Tunarungu Negeri Tulungagung.

Menghadapi anak-anak, dibutuhkan kesabaran, pengertian, dan toleransi yang mendalam. Mengharapkan mereka bisa mengerti sesuatu secara tepat, dengan membayangkan bahwa mereka adalah orang-orang seperti kita, tentu bukan merupakan sikap yang bijaksana.

Guru diharapkan mampu memegang peran sentral dalam pendidikan karakter agar anak didik bisa cepat menemukan bakatnya, kemudian tinggal mengasahnya secara tekun, kreatif dan produktif sehingga tampak di permukaan dan membawa manfaat bagi banyak orang. Demikian pendidikan menjadi jembatan yang melejitkan potensi individu dan media 
yang memberikan karya terbaik untuk publik. ${ }^{111}$

Kemandirian sangat penting untuk pertumbuhan siswa, yang digunakan terutama untuk memotivasi siswa agar dapat melakukan kemandirian dalam melaksanakan pembelajaran dengan baik secara perorangan maupun kelompok, hal itu akan sangat bermanfaat mendidik siswa untuk mematuhi dan menyenangi peraturan, prosedur, maupun kebijakan yang ada, sehingga dapat menghasilkan prestasi yang baik.

Guru mengajarkan kepada siswa melalui metode pembiasaan, dengan proses pembiasaan ini Siswa yang mandiri adalah Siswa yang memiliki kepercayaan diri dan motivasi yang tinggi. Sehingga dalam setiap tingkah lakunya tidak banyak menggantungkan diri pada orang lain, biasanya pada orang tuanya. Siswa yang kurang mandiri selalu ingin ditemani orang tuannya, baik pada saat disekolah maupun saat bermain. Para Siswa di Sekolah Dasar Luar Biasa Tunarungu Negeri Tulungagung siswanya memiliki kemandiran yang cukup, meskipun kelas I masih ada anak yang belum mandiri dan selalu minta ditemani orang tuannya, selaian itu berani memutuskan pilihannya sendiri, tingkat kepercayaan dirinya lebih nampak, dan mudah menyesuaikan diri dengan lingkungan dan teman bermain di lingkungan Sekolah Dasar Luar Biasa Tunarungu Negeri Tulungagung. Untuk kelas IV anak sudah mampu melaksanakan kegiatannya sendiri dan melaksanakan tugas yang diberikan oleh guru, sedangkan untuk anak yang ber IQ rendah karakter kemandiriannya belum terbentuk. hal. 84 .

${ }^{111}$ Jamal Ma'ruf Asmani, Buku Panduan Internalisasi Pendidikan Karakter disekolah..., 


\section{BAB VI}

\section{PENUTUP}

\section{A. Kesimpulan}

Berdasarkan paparan data, temuan data penelitian dan pembahasan hasil penelitian pada bab-bab sebelumnya, maka kesimpulan dari penelitian ini adalah:

1. Strategi guru Sekolah Dasar Luar Biasa Tunarungu Negeri Tulungagung dalam membentuk karakter kemandirian siswa dengan melakukan pembiasaan di sekolah antara lain, menyapu di dalam dan di luar kelas, membersihkan papan tulis setelah selesai pembelajaran, selalu mengucapkan salam jika bertemu teman, melaksanakan tugas dari guru, merawat diri sendiri tanpa bantuan orang lain.

2. Strategi guru dalam pelaksanaan pembentukan karakter kemandirian pada siswa di Sekolah Dasar Luar Biasa Tunarungu Negeri Tulungagung dengan mengadakan lomba-lomba antar kelas maupun lomba siswa dalam kelas yaitu, lomba mewarnai, lomba melukis, lomba menyulam dan lomba memasak antar kelas.

3. Dampak pembentukan Karakter Kemandirian Siswa di Sekolah Dasar Luar Biasa Tunarungu Negeri Tulungagung antara lain mau bersosialisasi dengan teman lain kelas, mampu mengerjakan soal-soal yang diberikan guru dan kemandirianya bisa masak sendiri di sekolah dan di rumah. Masih ada yang belum bisa melakukan aktifitasnya sendiri, dan masih tergantung pada orang lain. 


\section{B. Implikasi}

Hasil dari penelitian ini akan memberikan tawaran baru konsep pengembangan karakter kemandirian pada siswa di Sekolah Dasar Luar Biasa Tunarungu Negeri Tulungagung, serta kebijakan mengoptimalkan penerapannya, berdasarkan hasil penelitian yang peneliti paparkan hasil penelitian ini memberikan implikasi terhadap pengembangan kajian pendidikan karakter kemandirian. Salah satu temuan penelitian menunjukkan bahwa kemandirian siswa dalam setiap proses pembelajaran dipengaruhi oleh motivasi dari sang guru, lingkungan sekolah dan pembiasaan terhadap hal-hal positif, sehingga para siswa dapat mengaplikasikanya dalam kehidupan sehari-hari baik di lingkungan sekolah, maupun di keluarga dan masyarakat.

Dari hasil penelitian tentang Strategi guru Sekolah Dasar Luar Biasa Tunarungu Negeri Tulungagung, dalam membentuk karakter kemandirian pada siswa melalui pembiasaan ini akan memberikan pengaruh positif kepada kepala sekolah, dan guru-guru di tingkat sekolah dalam proses pendampingan terhadap pengembangan bakat, minat dan potensi para siswa serta proses belajar siswa. Motivasi yang baik dari kepala sekolah dan guru-guru dapat menjadikan para siswa yang tangguh di masa mendatang. Para pendidik sudah sepatutnya memperlakukan sebagai individu yang merdeka, yang memiliki potensi untuk berkembang dan di aktualisasikan. Menjadi kurang tepat jika pendidikan menjadikan sekolah sebagai sarana transfer pengetahuan saja akan tetapi sebagai tempat pembentukan karakter atau nilai-nilai kehidupan. 


\section{Saran}

Berdasarkan Berdasarkan uraian dalam penelitian ini, ada beberapa saran yang peneliti identifikasi dari berbagai pihak yang diharapkan dapat menjadi masukan dalam penelitian selanjutnya, sehingga dapat menghasilkan penelitian yang lebih lagi sesuai dengan sasaran penelitian, diantaranya adalah :

1. Kepala sekolah atau pengelola lembaga pendidikan perlu menata orientasi sekolah agar tidak semata menjadikan siswa unggul secara kognitif. Dengan bukti prestasi pada kejuaraan atau perlombaan, melainkan lebih pada upaya mempersiapkan siswa menjadi individu yang tangguh menghadapi masalah yang di temui di depanya, memiliki akhlak yang baik di lingkungan masyarakat, serta memiliki kepedulian sosial. Dan mengadakan kerjasama dengan semua Pihak yang berada di sekolah diantaranya guru-guru, dan wali Murid.

2. Bagi guru: pendidikan karakter kemandirian diharapkan mampu menjadi wahana yang kontruktif bagi peningkatan pendidikan di sekolah. Kegiatan pembelajaran tidak seharusnya hanya menumbuhkan intelektual saja, apalagi ini siswa berkebutuhan khusus yang membutuhkan penanganan khusus, akan tetapi juga juga membutuhkan internalisasi nilai dan budaya, sehingga menjadikan siswa lebih responsif terhadap realitas yang ada dan pada lingkungan sekitarnya.

3. Para orang tua dan siswa hendaknya mengerti dan paham tujuan pendidikan karakter yang tidak fokus pada nilai-nilai tinggi pada lembaran ijazah, melainkan lebih pada upaya membantu siswa untuk menemukan potensi siswa, untuk di kembangkan dan diaktualisasikan. 


\section{DAFTAR RUJUKAN}

Abar, B. dan Loken, E. 2010. Self-Regulated Learning and Self-Directed Study in a Precollege Sample. Learning and Individual Differences, 20(1), 25-29.

Afandi, Muhamad. dan Galuh. 2013. Pendidikan Anak Berkebutuhan Khusus. Semarang: Unisulla Press.

Al Fatihah, Miftaqul. 2016. Hubungan Antara Kemandirian Belajar dengan Prestasi Belajar Pai Siswa Kelas III SDN Panularan Surakarta. At-Tanbawi, 1(2), 197-203.

Arief, Armai. 2002. Pengantar Ilmu dan Metodologi Pendidikan Islam. Jakarta: Ciputat Press.

Asbar, Andi Muhammad. 2018. Strategi Guru dalam Pengelolaan Kelas pada Pembelajaran Pendidikan Agama Islam di Smp Negeri 39 Bulukumba. Jurnal Ilmiah Al Qalam, 12(1), 89-112.

Asmani, Jamal Ma'ruf. 2013. Buku Panduan Internalisasi Pendidikan Karakter disekolah Cet VI. Yogjakarta: Diva Press.

Awwad, Muhammad. 2015. Urgensi Layanan Bimbingan dan Konseling bagi Anak Berkebutuhan Khusus. Al-Tazkiah, 7(1), 46-64.

Aziz, Safrudin. 2014. Pendidikan Seks bagi Anak Berkebutuhan Khusus. Jurnal Kependidikan, 2(2), 182-201.

Bahri, Hasan. 2000. Remaja Berkualitas (Problema Remaja dan Solusinya). Yogyakarta: Pustaka Pelajar.

Barnawi dan M Arifin. 2012. Pendidikan Karakter Strategi dan Kebijakan Pembelajaran. Jogjakarta: Ar Ruzz Media.

Battistich, Victor. 2010. Character Education, Preventation, and Positive Youth Development of University of Missouri St Louis. Journal of social Scine, Vol. 01, No. 2.

Bong, M. 2004. Academic Motivation in Self-efficacy, Task Value, Achievement Goal Orientation and Attributional Beliefs. Journal of Educational Research, 97(6), 115-125.

Dermawan, Oki. 2013. Strategi Pembelajaran bagi Anak Berkebutuhan Khusus di SLB. Psympathic, Jurnal Ilmiah Psikologi, 4(2), 886-897.

Desmita. 2011. Psikologi Perkembangan Peserta Didik Cet III. Bandung: PT Remaja Rosdakarya. 
Dwi Agustin, Leonita dan Weny Savitry S. Pandi. 2014. Pemahaman Pedagogik Guru dalam Mengajar Anak Berkebutuhan Khusus di Sekolah Inklusi. Provitae Jurnal Psikologi Pendidikan. Vol. 6, No. 1.

Echlos, John M. dan Hasan Shadily. 2003. An English-Indonesian Dictionary. Jakarta: PT. Gramedia Pustaka Utama.

Efendi, Mohammad. 2006. Pengantar Psikopedagogik Anak Berkelainan. Jakarta: PT BumiAksara.

Egok, Asep Sukenda. Kemampuan Berpikir Kritis dan Kemandirian Belajar dengan Hasil Belajar Matematika. Jurnal Pendidikan Dasar, 7(2), 185-198.

Fadlillah, Muhammad dan Lilif Mualifatu Khorida. 2013. Pendidikan Karakter Anak Usia Dini:

Konsep dan Aplikasinya dalam PAUD. Jogjakarta: Ar-Ruzz Media.

Hadi, Fida Rahmantika. 2014. Analisis Proses Pembelajaran Matematika pada Anak Berkebutuhan Khusus (ABK) Slow Learners di Kelas Inklusi (Penelitian Dilakukan di SD Al Firdaus Surakarta). Tesis, Pascasarjana, Universitas Sebelas Maret Surakarta.

Haerudin. 2015. Pembelajaran dengan Pendekatan Savi untuk Meningkatkan Kemampuan Penalaran Matematik dan Kemandirian Belajar Siswa SMP. Jurnal Pendidikan Unsika, 3(1), 23-33.

Hamdani. 2011. Strategi Belajar Mengajar. Bandung: Pustaka Setia.

Hiemstra, Roger. 2003. More Than Three Decades of Self-Directed Learning: From Whence Have We Come?. Adult Learning, 14(5), 1-8

Jayantini, Ni Md. Sri., dkk. 2014. Hubungan Pola Asuh Orang Tua terhadap Kemandirian Belajar Siswa Kelas XI SMA Negeri 1 Sukasada Tahun Pelajaran 2013/2014. E-Journal Undiksa Jurusan Bimbingan Konseling, 2(1), 1-10.

Kamus Besar Bahasa Indonesia dalam Kbbi.web.id.

Kemendiknas. 2011. Panduan Pelaksanaan Pendidikan Karakter. Jakarta: Puskurbuk Kemendiknas.

Kementrian Pendidikan Nasional. 2011. Panduan Pelaksanaan Pendidikan Karakter. Jakarta: Puskurbuk Kemendiknas.

Khan, Yahya. 2010. Pendidikan Karakter Berbasis Potensi Diri. Yogyakarta: Pelangi Publishing.

Knowles dalam Su-fen cheng, dkk. 2010. Development and Preliminary Testing of A self-rating Instrument to Measure Self-directed Learning Ability of Nursing Students. International Journal of Nursing Studies, Vol. 47, No. 9. 
Kunandar. 2009. Guru Profesional Implementasi Kurikulum Tingkat Satuan Pendidikan (KTSP). Jakarta: PT Raja Grafindo Persada.

Kurniawan, Syamsul . 2014. Pendidikan Karakter: Konsepsi \& Implementasinya secara Terpadu di Lingkungan Keluarga, Sekolah, Perguruan Tinggi, dan Masyarakat. Yogyakarta: Ar-Ruzz Media.

Kusuma dan Darma. 2011 Pendidikan Karakter Kajian Teori dan Praktik Di Sekolah. Bandung: Rosda Karya.

Lie, Anita, Sarah Prasasti. 2004. Menjadi Orang Tua Bijak, 101 Cara Membina Kemandirian dan Tanggung Jawab Anak. Jakarta: Elex Media Komputindo.

Lickona, T. 1991. Education for Character: How Our Schools can Teach Respect and Responsibility. New York: Bantam Books.

Madjid, Abdul. 2011. Pendidikan Karakter Perspektif Islam. Bandung: Rosdakarya.

Mahmud, Muhdar. 2003. Layanan Bimbingan bagi Anak Berkebutuhan Khusus di Sekolah Dasar Wilayah Kota Bandung. Tesis, Pascasarjana, Universitas Pendidikan Indonesia.

Maftuhatin, Lilik. Evaluasi Pembelajaran Anak Berkebutuhan Khusus (ABK) di Kelas Inklusif di SD Plus Darul 'Ulum Jombang. Religi: Jurnal Studi Islam, 5(2), 201-227.

Mansyur, Agus Salim. 2007. Pengembangan Kurikulum Berbasis Karakter: Konsepsi dan Implmentasinya. Jurnal Pendidikan Universitas Garut, 01(01), 1-9.

Marlinda, Evi. 2011. Pengalaman Ibu dalam Merawat Anak dengan Keutuhan Khusus: Autis di Banjarbaru Kalimantan Selatan. Tesis, Pascasarjana, Universitas Indonesia.

Mashur, Rena Lestari dan Dahlia. 2015. Analisis Kemandirian Belajar Siswa Kelas Vii Pada Mata Pelajaran Ipa Terpadu Di Smp Negeri 1 Rambah Samo Kabupten Rokan Hulu Tahun Pembelajaran 2014/2015. E-jurnal Mahasiswa Prodi Biologi, 1(1), 1-3.

Mudjiman, Haris. 2011. Belajar Mandiri. Surakarta: UNS Press.

Mufarokah, Anissatul. 2013. Strategi dan Model-model Pembelajaran. Tulungagung, STAIN Press.

Mulyasa, ed. Dewi Ispurwanti. 2003. Manajemen Pendidikan Karakter. Jakarta: Bumi Aksara.

Mulyatiningsih, Endang . Analisis Model-model Pendidikan Karakter Usia Aanak-anak, Remaja dan Dewasa. Jurnal UNY. Volume 4. 
Mulyono, Abdurrahman. 2010. Pendidikan Bagi Anak Berkesulitan belajar. Jakarta: Rineka Cipta.

Munandar, Sc Utami. 2011. Kreatifitas dalam keberbakatan. Jakarta: Gramedia.

Nata, Abudin. 1997. Filsafat Pendidikan Islam. Jakarta: Logos Wacana Ilmu.

Negoro, Suratina Tirto. 2008. Kecenderungan Hidup Mandiri. Bandung: Tarsito.

Nizar, Samsul. 2000. Pendidikan Filsafat Islam. Jakarta: Ciputat Press.

Nurchotimah, Siti. 2013. Implementasi Kurikulum Pendidikan Berkarakter di Sekolah. Seminar Nasional Evaluasi Pendidikan Tahun 2013 di Unes. dari unnes.ac.id.

Pemerintah Republik Indonesia. 2010. Kebijakan Nasional Pembangunan Karakter Bangsa. Jakarta: Pemerintah Repubilk Indonesia.

Peraturan Pemerintah Republik Indonesia Nomor 72 Tahun 1991 tentang Pendidikan Luar Biasa. Jakarta: Pemerintah Repubilk Indonesia.

Peraturan Menteri Pendidikan dan Kebudayaan Nomor 62 Tahun 2014 tentang Kegiatan Ekstrakurikuler. Jakarta: Kementerian Pendidikan dan Kebudayaan.

Pramartha, I Nyoman Bayu. 2015. Sejarah dan Sistem Pendidikan Sekolah Luar Biasa Bagian A Negeri Denpasar Bali. Jurnal Historia, 3(2), 67-74.

Rabbi, Muhammad dan Muhammad Jauhari. 2006. Akhlaquna, terjemahan. Dadang Sobar Ali. Bandung : Pustaka Setia.

Rianawati. 2014. Internalisasi Karakter Kemandirian Melalui Pembelajaran Konstruktif Di Perguruan Tinggi. At-turats. Jurnal Pemikiran Pendidikan Islam, 8(2), 1-23.

Rofiah, Nurul Hidayati. 2015. Bimbingan Belajar Untuk Anak Berkebutuhan Khusus di Sekolah Dasar. Prosiding Seminar Nasional dan Call for Papers Universitas Muhammadiyah Semarang, 257-258.

Sanjaya, Wina. 2007. Strategi Pembelajaran Berorientasi Standar Proses Pendidikan. Jakarta: Kencana.

Sriyanto, 2013. Pengelolaan Pendidikan Karakter pada Kegiatan Pengembangan Diri di SD Muhammadiyah 1 Wonogiri. Tesis, Program Pascasarjana, Universitas Muhammadiyah Surakarta.

Sugiyono. 2014. Metode Penelitian Pendidikan Pendekatan Kuantitatif, Kualitatif Dan $R \& D$. Bandung: Alfabeta.

Supardjo. 2016. Pengelolaan Pembelajaran Anak Berkebutuhan Khusus Di Sekolah Dasar Penyelenggaran Pendidikan Inklusif Sekolah Dasar Negeri 
III Giriwono Wonogiri. Tesis, Pascasarjana, Universitas Muhammadiyah Surakarta.

Suparno. 2007. Pendidikan Anak Berkebutuhan Khusus. Jakarta: Dirjen Dikti Depdiknas.

Suparno, P. 2002. Reformasi Pendidikan. Yogyakarta: Kanisius.

Syukur. Amin. 2010. Studi akhlak. Semarang: Wali Songo Press.

Syah, Muhibbin. 2010. Psikologi Pendidikan Dengan Pendekatan Baru. Bandung: PT Remaja Rosdakarya.

Tirtarahardja, Umar. 2005. Pengantar Pendidikan. Jakrta: Rineka Cipta.

Thoha, Chabib. 1996. Kapita Selekta Pendidikan Islam. Yogyakarta: Pustaka Pelajar IKAPI.

Undang-undang Republik Indonesia Nomor 20 Tahun 2003 tentang Sistem Pendidikan Nasional. Jakarta: Pemerintah Republik Indonesia.

Wibowo, Agus. 2012. Pendidikan Karakter Strategi Membangun Karakter Bangsa Berperadaban. Yogyakarta: Pustaka Belajar.

Wuryandani, Wuri. 2016. Implementasi Karakter Kemandirian di Muhammadiyah Boarding School. Jurnal cakrawala Pendidikan. Th 35, No. 2.

Yamin, Martinis. 2013. Strategi dan Metode Dalam Model Pembelajaran, Referensi. Jakarta: Gp Press Goup.

Yusuf, Syamsu. 2008. Psikologi Perkembangan Anak. Bandung: Remaja Rosdakarya.

Zins, Joseph., dkk. 2004. Building Academic Succes on Social and Emotional Learning. New York and London: Teachers College Press.

Zubaidi. 2010. Desain Pendidikan Karakter Konsepsi dan Aplikasinya dalam Lembaga Pendidikan. Jakarta: PT. Rajagrafindo.

Zuchdi, Darmiyati. dkk. 2013. Pendidikan Karakter: Konsep Dasar dan Implementasi di Perguruan Tinggi. Yogyakarta: UNY Press.

Zuriah, Nurul. 2007. Pendidikan Moral dan Budi Pekerti dalam Prospek Perubahan. Jakarta: Bumi Aksara. 


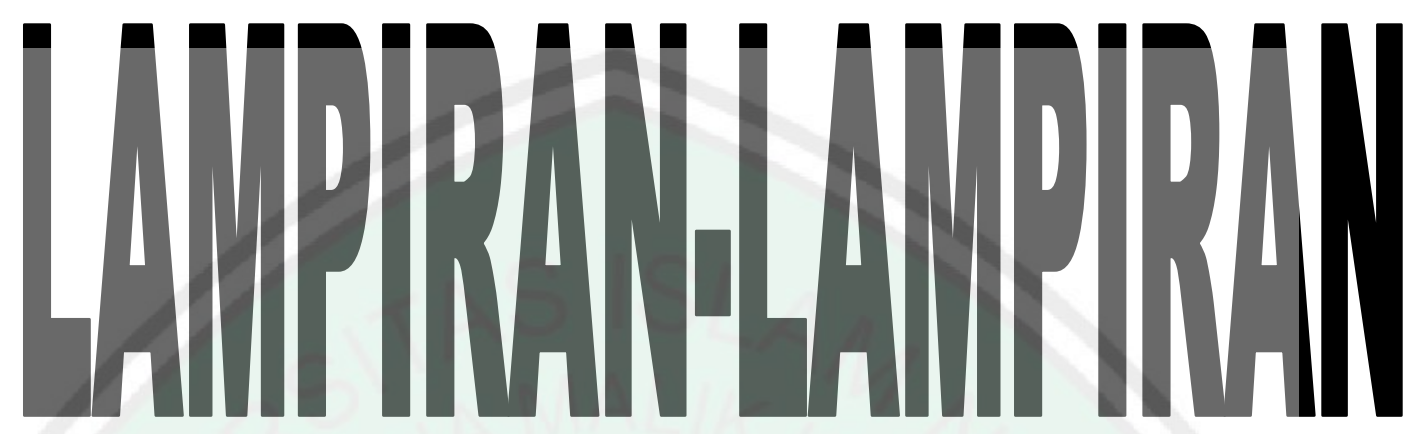

$\frac{1}{2}$

衣

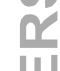

2

$\frac{0}{4}$

$\frac{1}{1}$

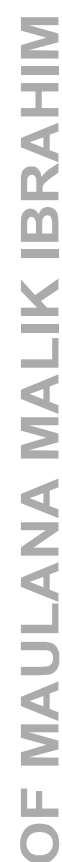




\section{VISI DAN MISI}

\section{Visi}

Mendidik siswa bisa mandiri, berkemampuan optimal dan berakhlak mulia.

\section{Misi}

1. Melaksanakan kegiatan belajar mengajar mengacu pada perundang-undangan yang berlaku.

2. Melaksanakan program kurikulum yang berlaku.

3. Menambahkan kegiatan ketrampilan.

4. Menambah bimbingan agama.

\section{Tujuan Sekolah}

1. Menampung anak berkebutuhan khusus (anak luar biasa/penyandang ketunaan) di daerah Tulungagung dan sekitarnya dalam lembaga pendidikan formal.

2. Mengembangkan potensi anak didik untuk menghadapi masa depan mereka yang kompetitif.

3. Memberikan pelayanan pendidikan secara utuh dan berkesinambungan. 


\section{TATA TERTIB SEKOLAH}

\section{HAL MASUK SEKOLAH}

1. Semua murid harus masuk Sekolah selambat-lambatnya 5 menit sebelum pelajaran dimulai.

2. Murid yang datang terlambat tidak diperkenankan langsung masuk kelas, melainkan harus meminta maaf kepada guru dan teman-temannya.

3. a. Murid absen hanya karena benar-benar sakit atau ada keperluan yang sangat penting, tidak bisa diwakilkan.

b. Urusan keluarga harus dikerjakan diluar sekolah atau (waktu libur sehingga tidak menggunakan hari sekolah)

c. Murid yang absen pada waktu masuk kembali harus melapor kepada kepala sekolah dengan membawa surat-surat yang diperlukan.

d. Murid tidak diperbolehkan meninggalkaan sekolah selama jam pelajaran berlangsung.

e. Kalau seandainya murid merasa sakit di rumah maka sebaiknya tidak masuk sekolah dan memberikan keterangan kepada sekolah.

\section{KEWAJIBAN MURID}

1. Taat kepada guru-guru dan kepala sekolah

2. Ikut bertanggung jawab atas kebersihan, keamanan, ketertiban dan sekolah pada umumnya.

3. Ikut bertanggung jawab atas pemeliharaan gedung, halaman, perabot, dan peralatan sekolah.

4. Membantu kelancaran pelajaran baik di kelasnya maupun di sekolah. 
5. Ikut menjaga nama baik sekolah, guru dan pelajar pada umumnya baik di dalam maupun di luar sekolah.

6. Menghormati guru dan saling menghargai antar sesama murid

7. Melengkapi diri dengan keperluan sekolah.

8. Ikut membantu agar tata tertib sekolah dapat berjalan dan ditaati

\section{LARANGAN MURID}

1. Meninggalkan sekolah selama pelajaran berlangsung. Penyimpangan dalam hal ini hanya dengan izin kepala sekolah.

2. Membeli makan dan minum diluar sekolah

3. Menerima surat-surat atau tamu di kelas.

4. Memakai perhiasan yang berlebihan serta berdandan yang tidak sesuai dengan kepribadian bangsa.

5. Merokok di dalam dan luar sekolah.

6. Menggangu jalanya pelajaran baik terhadap kelasnya maupun kelas lain.

7. Berada di dalam kelas selama waktu istirahat.

8. Berkelahi dan main hakim sendiri jika menemui peroalan antar teman.

9. Menjadi kumpulan anak-anak nakal dan geng-geng terlarang

\section{HAL PAKAIAN DAN LAIN-LAIN}

1. Setiap murid wajib memakai seragam sekolah lengkap sesuai dengan ketentuan sekolah

2. Murid-murid putri dilarang memelihara kuku panjang dan memakai alat kecantikan kosmetik yang lazim digunakan orang-orang dewasa.

3. Rambut di potong rapi, bersih dan terpelihara

4. Pakaian olahraga sesuai dengan ketentuan sekolah. 


\section{HAK-HAK MURID}

1. Murid-murid berhak mengikuti pelajaran selama tidak melanggar tata tertib

2. Murid-murid dapat meminjam buku-buku dari perpustakaan sekolah dengan mentaati peraturan perpustakaan yang berlaku.

3. Murid-murid berhak mendapatkan perlakuan yang sama dengan murid-murid yang lain sepanjang tidak melanggar TATA TERTIB.

\section{LAIN-LAIN}

1. Hal-hal yang belum tercantum dalam peraturan Tata Tertib ini diatur oleh sekolah.

2. Peraturan Tata Tertib sekolah ini berlaku sejak diumumkan. 


\section{TATA TERTIB KELAS}

1. Setelah tanda bel masuk dibunyikan semua siswa harus sudah berada di kelas.

2. Siswa-siswi diharuskan berdo'a sebelum pelajaran dimulai dan setelah pelajaran berakhir dipimpin oleh ketua kelas

3. 10 menit setelah bel masuk guru belum berada di kelas ketua kelas segera menghubungi guru piket.

4. Murid-murid yang terlambat harus memperlihatkan surat izin dari guru piket sebelum memasuki kelas.

5. Anak yang datang terlambat tanpa alasan yang tepat tidak diperkenankan mengikuti jam pelajaran pertama dan hari berikutnya harus membawa surat keterangan dari orang tua.

6. Tugas yang diberikan guru (PR) setelah dikerjakan harus dimintakan tanda tangan dari orang tua atau wali dan tidak boleh mengerjakan PR di sekolah.

7. Selama pelajaran murid-murid tidak diperkenankan meninggalkan kelas tanpa izin guru.

8. Murid-murid yang tidak masuk sekolah, pada hari berikutnya harus membawa surat izin dari orang tua atau wali atau pemberitahuan lewat telepon.

9. Murid-murid tidak diperkenankan pindah-pindah tempat duduk selama pelajaran kecuali selama pelajaran kelompok.

10. Selama kegiatan belajar mengajar berlangsung murid-murid tidak diperkenankan bercanda, berteriak, melakukan kegiatan yang mengganggu proses belajar mengajar.

11. Murid-murid wajib memiliki buku pelajaran bagi yang mampu. 
12. Seluruh murid berkewajiban menjaga dan merawat sarana dan prasarana dikelas termasuk meja, kursi, papan tulis, alat kebersihan dan lain-lain.

13. Kebersihan kewajiban dan keindahan kelas menjadi tanggung jawab ketua kelas, guru piket dan seluruh siswa. 


\section{Instrument Wawancara untuk Kepala Sekolah}

1. Berapa lama Bapak menjadi Kepala di Sekolah Dasar Luar Biasa Tunarungu Negeri Tulungagung?

2. Bagaimana sejarah berdirinya Sekolah Dasar Luar Biasa Tunarungu Negeri Tulungagung?

3. Apa Visi dan Misi dari Sekolah Dasar Luar Biasa Tunarungu Negeri Tulungagung?

4. Bagaimana keadaan sarana dan prasarana penunjang untuk pembentukan karakter kemandirian belajar siswa di Sekolah Dasar Luar Biasa Tunarungu Negeri Tulungagung?

5. Bagaimana pendapat bapak selaku kepala madrasah tentang karakter kemandirian belajar yang di miliki oleh siswa di Sekolah Dasar Luar Biasa Tunarungu Negeri Tulungagung?

6. Apa kegiatan ektra kurikuler yang dilakukan disekolah ini untuk bisa mengembangkan karakter kemandirian belajar siswa di Sekolah Dasar Luar Biasa Tunarungu Negeri Tulungagung?

7. Bagaimana kerjasama bapak sebagai kepala sekolah dengan guru-guru dan wali kelas untuk mengembangkan karakter kemandirian belajar pada siswa di Sekolah Dasar Luar Biasa Tunarungu Negeri Tulungagung?

8. Bagaimana proses pembentukan karakter kemandirian belajar pada siswa melalui metode pembiasaan di Sekolah Dasar Luar Biasa Tunarungu Negeri Tulungagung? 
9. Bagaimana Strategi bapak selaku kepala Sekolah Dasar Luar Biasa Tunarungu Negeri Tulungagung dalam melaksanakan pembentukan karakter kemandirian belajar pada Siswa melalui metode pembiasaan?

10. Apa sajakah kebijakan dari bapak sebagai kepala Sekolah Dasar Luar Biasa Tunarungu Negeri Tulungagung untuk mengembangkan karakter kemandirian belajar siswa melalui metode pembiasaan?

11. Bagiamana karakter kemandirian belajar yang di miliki siswa di Sekolah Dasar Luar Biasa Tunarungu Negeri Tulungagung? 


\section{Instrument wawancara untuk guru dan wali kelas}

1. Seperti apa keadaan di Sekolah Dasar Luar Biasa Tunarungu Negeri Tulungagung?

2. Bagaimana Menurut Bapak/ Ibu karakter kemandirian belajar siswa di Sekolah Dasar Luar Biasa Tunarungu Negeri Tulungagung kemandirian yang telah ada pada diri siswa?

3. Apa program khusus dari Bapak/ ibu yang bisa ibu lakukan untuk membentuk karakter kemandirian belajar pada siswa melalui metode pembiasaan di sekolah ini?

4. Bagaimana kerjasama Bapak/ Ibu sebagai wali kelas/ guru dengan kepala sekolah untuk membentuk karakter kemandirian belajar pada siswa melalui metode pembiasaan?

5. Apa kendala yang dihadapi oleh bapak/ibu dalam proses pembentukan karakter kemandirian belajar pada siswa?

6. Apa solusi dari bapak/ibu untuk mengatasi kendala-kendala tersebut?

7. Bagaimana proses pelaksanaan pembentukan karakter kemandirian belajar pada siswa di Sekolah Dasar Luar Biasa Tunarungu Negeri Tulungagung?

8. Bagaimana Strategi Bapak/ibu dalam pembentukan karakter kemandirian belajar pada Siswa melalui metode pembiassaan di Sekolah Dasar Luar Biasa Tunarungu Negeri Tulungagung?

9. Bagiamana Karakter Kemandirian belajar yang di miliki siswa di Sekolah Dasar Luar Biasa Tunarungu Negeri Tulungagung? 


\section{PEDOMAN PENGUMPULAN DATA}

\section{A. Pedoman Observasi}

1. Letak dan keadaan geografis Sekolah Dasar Luar Biasa Tunarungu Negeri Tulungagung.

2. Kondisi dan situasi di lingkungan Sekolah Dasar Luar Biasa Tunarungu Negeri Tulungagung.

3. Keadaan kelas di Sekolah Dasar Luar Biasa Tunarungu Negeri Tulungagung.

4. Aktivitas siswa Sekolah Dasar Luar Biasa Tunarungu Negeri Tulungagung.

5. Aktivitas Guru Sekolah Dasar Luar Biasa Tunarungu Negeri Tulungagung.

6. Strategi pengembangan karakter kemandirian belajar siswa melalui metode pembiasaan di Sekolah Dasar Luar Biasa Tunarungu Negeri Tulungagung.

B. Pedoman dokumentasi

1. Sejarah berdirinya dan berkembangnya Sekolah Dasar Luar Biasa Tunarungu Negeri Tulungagung.

2. Struktur organisasi Sekolah Dasar Luar Biasa B Negeri Tulungagung.

3. Keadaan guru dan siswa di Sekolah Dasar Luar Biasa Tunarungu Negeri Tulungagung.

4. Tata Tertib di Sekolah Dasar Luar Biasa Tunarungu Negeri Tulungagung.

5. Sarana dan prasarana di SDLB Tunarungu Negeri Tulungagung. 


\section{Pedoman Wawancara}

1. Wawancara dengan Kepala Sekolah Dasar Luar Biasa Tunarungu Negeri Tulungagung.

a. Nama, latar belakang pendidikan dan berapa lama menjadi kepala Sekolah Dasar Luar Biasa Tunarungu Negeri Tulungagung.

b. Sejarah berdirinya Sekolah Dasar Luar Biasa Tunarungu Negeri Tulungagung.

c. Visi dan Misi Sekolah Dasar Luar Biasa Tunarungu Negeri Tulungagung.

d. Sarana dan prasaran di Sekolah Dasar Luar Biasa Tunarungu Negeri Tulungagung.

e. Karakteristik pendidik di Sekolah Dasar Luar Biasa Tunarungu Negeri Tulungagung.

f. Pandangan umum terkait karakter kemandirian belajar siswa di Sekolah Dasar Luar Biasa Tunarungu Negeri Tulungagung.

g. Proses ,Strategi dan kendala dalam membentuk karakter kemandirian belajar siswa melalui metode pembiasaan di Sekolah Dasar Luar Biasa Tunarungu Negeri Tulungagung.

h. kebijakan-kebijakan dari kepala Sekolah Dasar Luar Biasa Tunarungu Negeri Tulungagung.

i. Proses pembentukan karakter siswa di Sekolah Dasar Luar Biasa Tunarungu Negeri Tulungagung

j. Dampak pembentukan karakter kemandirian belaja siswa di Sekolah Dasar Luar Biasa Tunarungu Negeri Tulungagung. 
2. Wawancara dengan Guru-guru di Sekolah Dasar Luar Biasa Tunarungu Negeri Tulungagung

a. Nama, latar pendidikan, lama mengajar di Sekolah Dasar Luar Biasa Tunarungu Negeri Tulungagung

b. Karakteristik siswa di Sekolah Dasar Luar Biasa Tunarungu Negeri Tulungagung

c. Kerjasama guru-guru dalam mengembangkan karakter kemandirian siswa melalui metode pembiasaan.

d. Proses ,Strategi dan kendala dalam membentuk karakter kemandirian belajar siswa melalui metode pembiasaan di Sekolah Dasar Luar Biasa Tunarungu Negeri Tulungagung.

e. Sarana dan prasaran di Sekolah Dasar Luar Biasa Tunarungu Negeri Tulungagung

f. Kerjasama guru- guru dalam menyukseskan kebijakan-kebijakan dari kepala Sekolah Dasar Luar Biasa Tunarungu Negeri Tulungagung.

g. Proses pembentukan karakter siswa di Sekolah Dasar Luar Biasa Tunarungu Negeri Tulungagung

h. Hubungan antara guru-guru dengan wali murid Sekolah Dasar Luar Biasa Tunarungu Negeri Tulungagung. 
LEMBAR OBSERVASI SARANA DAN PRASARANA SEKOLAH

DASAR LUAR BIASA TUNARUNGU NEGERI

TULUNGAGUNG

\begin{tabular}{|c|c|c|c|c|}
\hline \multirow[t]{2}{*}{ No } & \multicolumn{4}{|c|}{ Sarana } \\
\hline & Nama Barang & Banyaknya & Rusak Ringan & Rusak Berat \\
\hline 1 & Meja siswa & 50 & 10 & - \\
\hline 2 & Kursi siswa & 50 & - & - \\
\hline 3 & Meja guru & 6 & - & - \\
\hline 4 & Kursi guru & 6 & - & - \\
\hline 5 & Almari & 7 & - & - \\
\hline 6 & Rak & 3 & - & - \\
\hline 7 & Papan tulis & 6 & - & - \\
\hline 8 & Papan pengumuman & 1 & - & - \\
\hline 9 & Papan data kelas & 6 & 2 & - \\
\hline 10 & Tape recorder & 1 & - & - \\
\hline 11 & Komputer & 2 & - & 1 \\
\hline 12 & Printer & 1 & - & - \\
\hline 13 & TV & - & - & - \\
\hline 14 & VCD & - & - & - \\
\hline
\end{tabular}


DAFTAR NAMA-NAMA GURU DI SEKOLAH DASAR LUAR BIASA TUNARUNGU NEGERI TULUNGAGUNG

\begin{tabular}{|c|c|c|}
\hline NO & NAMA & JABATAN \\
\hline 1. & $\begin{array}{l}\text { Drs. Sudarminto } \\
\text { NIP } 195903151983031025\end{array}$ & Kepala Sekolah \\
\hline 2. & $\begin{array}{l}\text { Dra. Yayuk Triani } \\
\text { NIP } 198702178090103123\end{array}$ & Wakil Kurikulum \\
\hline 3. & $\begin{array}{l}\text { Dra. Tri Agus Winarni } \\
\text { NIP } 1963081519860320018\end{array}$ & Wali Kelas I \\
\hline 4. & Budi Santoso & Wali Kelas II \\
\hline 5. & $\begin{array}{l}\text { Imam Mulyakim } \\
\text { NIP } 195702011982081015\end{array}$ & Wali Kelas III \\
\hline 6. & Puput Novita Prasetya Sari & Wali Kelas IV \\
\hline 7. & Khoirul Anwar & Wali Kelas V \\
\hline 8. & Risa Yuliani Saputri & Wali Kelas VI \\
\hline 9. & Muhammad Abdul Ghofur & Guru Olahrag \\
\hline 10. & Sri Gunarsih & Petugas Perpustakaan \\
\hline 11. & Prayoga & Penjaga Sekolah \\
\hline
\end{tabular}




\section{LEMBAR WAWANCARA}

$\begin{array}{ll}\text { No } & : 1 \\ \text { Nama } & : \text { Bapak Sudarminto } \\ \text { Hari/tanggal } & : \text { 08 Oktober } 2018 \\ \text { Tema bahasan } & : \text { Peran Kepala Sekolah }\end{array}$

\begin{tabular}{|l|l|l|}
\hline No & \multicolumn{1}{|c|}{ Pertanyaan } & \multicolumn{1}{|c|}{ Jawaban } \\
\hline 1. & $\begin{array}{l}\text { Bagaimana peran kepala } \\
\text { sekolah dalam memajukan } \\
\text { kegiatan sekolah? }\end{array}$ & $\begin{array}{l}\text { Peran saya disini sebagai kepala sekolah } \\
\text { adalah mengkoordinasikan seluruh guru dalam } \\
\text { pelaksanaan program belajar mengajar, } \\
\text { memberikan motivasi kepada guru-guru untuk } \\
\text { membiasakan melakukan kegiatan positif } \\
\text { kepada para siswa. Setiap satu bulan sekali } \\
\text { mengadakan rapat bersama dewan guru untuk } \\
\text { mengevaluasi kinerja guru dalam } \\
\text { melaksanakan pembelajaran. } \\
\text { 2. }\end{array}$ \\
$\begin{array}{l}\text { Bagaimana strategi kepala } \\
\text { sekolah dalam membentuk } \\
\text { siswa? }\end{array}$ & $\begin{array}{l}\text { Saya sebagai kepala sekolah mempunyai cara } \\
\text { untuk membentuk karakter siswa dengan } \\
\text { melalui metode pembiasaan diantaranya } \\
\text { dengan kegiatan rutin sebelum memulai } \\
\text { pelajaran dan sebelum pulang dari sekolah } \\
\text { yakni anak-anak harus bersalaman dengan para } \\
\text { guru dan mengucapkan assalamualaikum yang } \\
\text { keras. Dengan begitu anak-anak akan terbiasa } \\
\text { dengan kegiatan itu secara langsung akan } \\
\text { terbentuk karakter kemandiriannya. Setiap satu } \\
\text { bulan sekali diadakan perlombaan diantaranya } \\
\text { lomba memasak dan menganyam dan } \\
\text { mewarnai dengan tujuan membiasakan anak } \\
\text { didik bisa mandiri melakukan tugasnya. }\end{array}$ \\
\hline
\end{tabular}




\section{LEMBAR WAWANCARA}

$\begin{array}{ll}\text { No } & : 2 \\ \text { Nama } & : \text { Ibu Yayuk } \\ \text { Hari/tanggal } & : \text { 09 Oktober } 2018 \\ \text { Tema bahasan } & : \text { Peran Wakil Kurikulum }\end{array}$

\begin{tabular}{|c|c|c|}
\hline No & Pertanyaan & Jawaban \\
\hline 1. & $\begin{array}{l}\text { Bagaimana peran ibu } \\
\text { sebagai wakil kurikulum? }\end{array}$ & $\begin{array}{l}\text { Peran saya sebagai wakil kurikulum yaitu } \\
\text { diantaranya membuat SK pembagian tugas } \\
\text { mengajar, menyusun kurikulum yang ada, } \\
\text { menyusun kalender akdemik, dan menyiapkan } \\
\text { daftar nilai untuk guru kelas dan guru mapel } \\
\text { serta memantau jalannya kegiatan } \\
\text { pembelajaran. }\end{array}$ \\
\hline 2. & $\begin{array}{l}\text { Bagaimana strategi Ibu } \\
\text { dalam membentuk } \\
\text { karakter kemandirian } \\
\text { siswa melalui metode } \\
\text { pembiasaan? }\end{array}$ & $\begin{array}{l}\text { Metode pembiasaan sangat erat hubungannya } \\
\text { dengan pembentukan karakter kemandirian } \\
\text { siswa dimana dengan diadakannya pembiasaan } \\
\text { yang positif akan membentuk kemandirian } \\
\text { siswa, dalam hal ini saya dan bapak kepala } \\
\text { sekolah melakukan kegiatan rutin setiap satu } \\
\text { bulan sekali mengadakan lomba-lomba, baik } \\
\text { lomba antar kelas ataupun antar sekolah. Untuk } \\
\text { kelas I sampai kelas III mengikuti lomba } \\
\text { mewarnai dan melukis sedangkan untuk kelas } \\
\text { IV sampai kelas VI lomba memasak dan } \\
\text { menganyam, lomba ini dilaksanakan selain } \\
\text { untuk membiasakan kegiatan positif pada } \\
\text { siswa juga untuk membentuk karakter } \\
\text { kemandirian siswa tersebut. }\end{array}$ \\
\hline
\end{tabular}




\section{LEMBAR WAWANCARA}

No $\quad: 3$

Nama : Ibu Puput

Hari/tanggal : 15 Oktober 2018

Tema bahasan : Menentukan strategi pembentukan karakter kemandirian siswa melalui metode pembiasaan

\begin{tabular}{|c|c|c|}
\hline No & Pertanyaan & Jawaban \\
\hline 1. & $\begin{array}{l}\text { Bagaimana peran ibu } \\
\text { sebagai wali kelas IV } \\
\text { menetukan strategi untuk } \\
\text { membentukan karakter } \\
\text { kemandirian siswa melalui } \\
\text { metode pembiasaan? }\end{array}$ & $\begin{array}{l}\text { Sebagai wali kelas IV saya mempunyai peran } \\
\text { penting dalam pelaksanaan pembentukan } \\
\text { karakter kemandirin siswa apalagi saya bukan } \\
\text { dari jurusan SLB. Disini saya membiasakan } \\
\text { para siswa diantaranya untuk meyapu ruangan } \\
\text { belajar (Kelas), menata ruangan belajar agar } \\
\text { bersih dan rapi yang diatur ketua kelas setiap } \\
\text { hari. Membiasakan para siswa untuk } \\
\text { membersihkan papan tulis sebelum memulai } \\
\text { pelajaran dan setelah pembejaran berlangsung } \\
\text { agar bersih untuk kegiatan belajar mata } \\
\text { pelajaran berikutnya. Membiasakan para siswa } \\
\text { membersihkan dalam dan luar kelas agar } \\
\text { sekolah menjadi tempat yang nyaman untuk } \\
\text { tempat menuntut ilmu, dan pembiasaan di } \\
\text { sekolah ini akan di laksanakan di rumah para } \\
\text { siswa. Dengan begitu siswa akan secara alami } \\
\text { melakukan kebiasan tersebut tanpa paksaan, } \\
\text { selain itu saya juga merangsang siswa dengan } \\
\text { memotivasinya untuk berani tampil di depan } \\
\text { kelas. }\end{array}$ \\
\hline
\end{tabular}




\begin{tabular}{|c|c|c|}
\hline 2. & $\begin{array}{l}\text { Bagaimana menurut anda } \\
\text { dampak adanya penerapan } \\
\text { karakter kemandirian } \\
\text { siswa melalui metode } \\
\text { pembiasaan tersebut? }\end{array}$ & $\begin{array}{l}\text { Dalam hal ini ada dampak positif dan } \\
\text { negatifnya tersendiri salah satu dampak } \\
\text { negatifnya yaitu disini saya sebagai wali kelas } \\
\text { IV yang basicnya bukan dari pendidikan SLB } \\
\text { masih mengalami kesulitan untuk memahami } \\
\text { karakter siswa, karena siswa luar biasa } \\
\text { memiliki emosional yang tidak stabil, sering } \\
\text { berubah-ubah. Anak-anak yang emosionalnya } \\
\text { kurang stabil karakter kemandiriannya juga } \\
\text { terhambat, untuk dampak positifnya siswa } \\
\text { secara tersendiri setelah melaksanakan } \\
\text { pembiasaan positif karakter kemandiriannya } \\
\text { sudah muncul. }\end{array}$ \\
\hline
\end{tabular}




\section{LEMBAR WAWANCARA}

No $\quad: 4$

Nama $\quad$ : Ibu Tri Agus Winarni

Hari/tanggal : 22 Oktober 2018

Tema bahasan : Menentukan strategi pembentukan karakter kemandirian siswa melalui metode pembiasaan

\begin{tabular}{|c|c|c|}
\hline No & Pertanyaan & Jawaban \\
\hline 1. & $\begin{array}{l}\text { Bagaimana peran ibu } \\
\text { sebagai wali kelas I } \\
\text { menetukan strategi untuk } \\
\text { membentukan karakter } \\
\text { kemandirian siswa melalui } \\
\text { metode pembiasaan? }\end{array}$ & $\begin{array}{l}\text { Saya sebagai wali kelas I dalam membentuk } \\
\text { karakter kemandirian siswa untuk kelas I } \\
\text { dengan cara mengupayakan yang pertama agar } \\
\text { anak-anak mau ditinggal orang tuanya, setelah } \\
\text { itu saya melakukan pembiasaan dengan } \\
\text { menyuruh anak-anak dirumah menyiapkan } \\
\text { peralatan sekolahnya sendiri, setiap pagi saya } \\
\text { bertanya kepada anak-anak siapa saja yang tadi } \\
\text { pagi sebelum berangkat sekolah menyiapkan } \\
\text { peralatannya sendiri, siapa saja yang sudah } \\
\text { menyiapkan peralatannya sendiri saya kasih } \\
\text { hadiah. Hal ini selain bisa membentuk karakter } \\
\text { kemandirian siswa juga bisa membiasakan diri } \\
\text { untuk berkata jujur. Saya juga membiasakan } \\
\text { dengan cara menerapkan anak supaya } \\
\text { membuang sampah (bungkus jajan dan } \\
\text { sebagainya) pada tempatnya dan menyuruh } \\
\text { anak-anak dirumah mandi sendiri tanpa } \\
\text { bantuan orangtua, di dalam kelas anak dilatih } \\
\text { untuk bisa menulis suatu kalimat yang ada di } \\
\text { papan tulis. }\end{array}$ \\
\hline
\end{tabular}




\begin{tabular}{|c|c|c|}
\hline 2. & $\begin{array}{l}\text { Bagaimana menurut anda } \\
\text { dampak adanya penerapan } \\
\text { karakter kemandirian } \\
\text { siswa melalui metode } \\
\text { pembiasaan tersebut? }\end{array}$ & $\begin{array}{l}\text { Dalam hal ini ada dampak positif dan } \\
\text { negatifnya tersendiri salah satu dampak } \\
\text { negatifnya. Anak kelas I atau kelas rendah } \\
\text { masih sulit dikendalikan, di mana mereka } \\
\text { masih berada ditahap peralihan dari sekolah } \\
\text { taman kanak-kanak (TK), dalam } \\
\text { pelaksanaannya memerlukan sedikit tenaga } \\
\text { ekstra. Disini saya lebih menekankan untuk } \\
\text { membiasakan anak untuk mandiri dengan saat } \\
\text { pembelajaran tidak } \\
\text { mendampinginya. Anak yang sudah mau } \\
\text { ditinggal orang tuanya dengan sendirinya dia } \\
\text { akan bisa membiasakan dirinya dengan } \\
\text { lingkungannya dan karakter kemandiriannya } \\
\text { akan mulai muncul. }\end{array}$ \\
\hline
\end{tabular}


Dokumentasi Kegiatan Di Sekolah Dasar Luar Biasa Tunarungu Negeri

\section{Tulungagung}

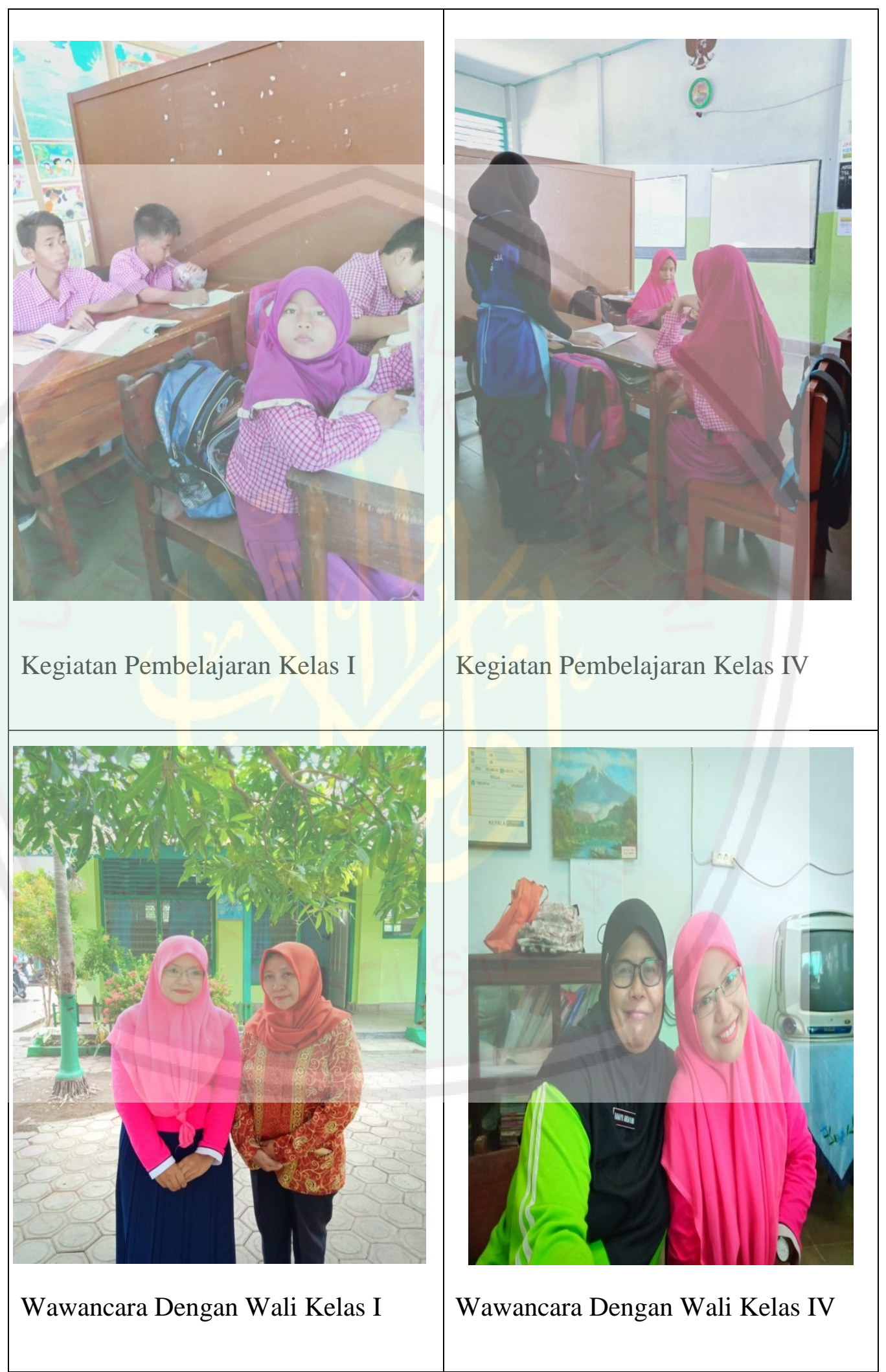




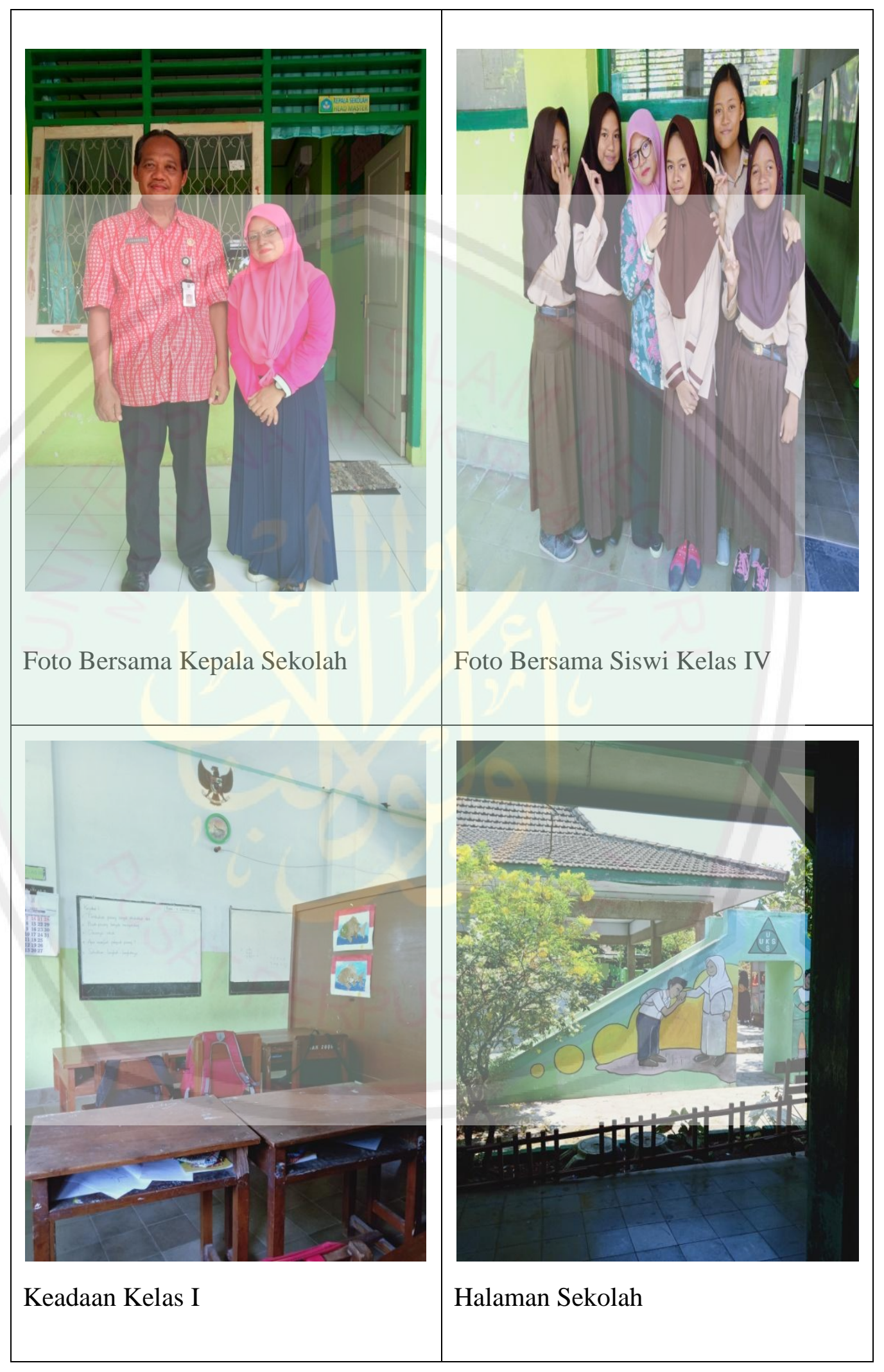




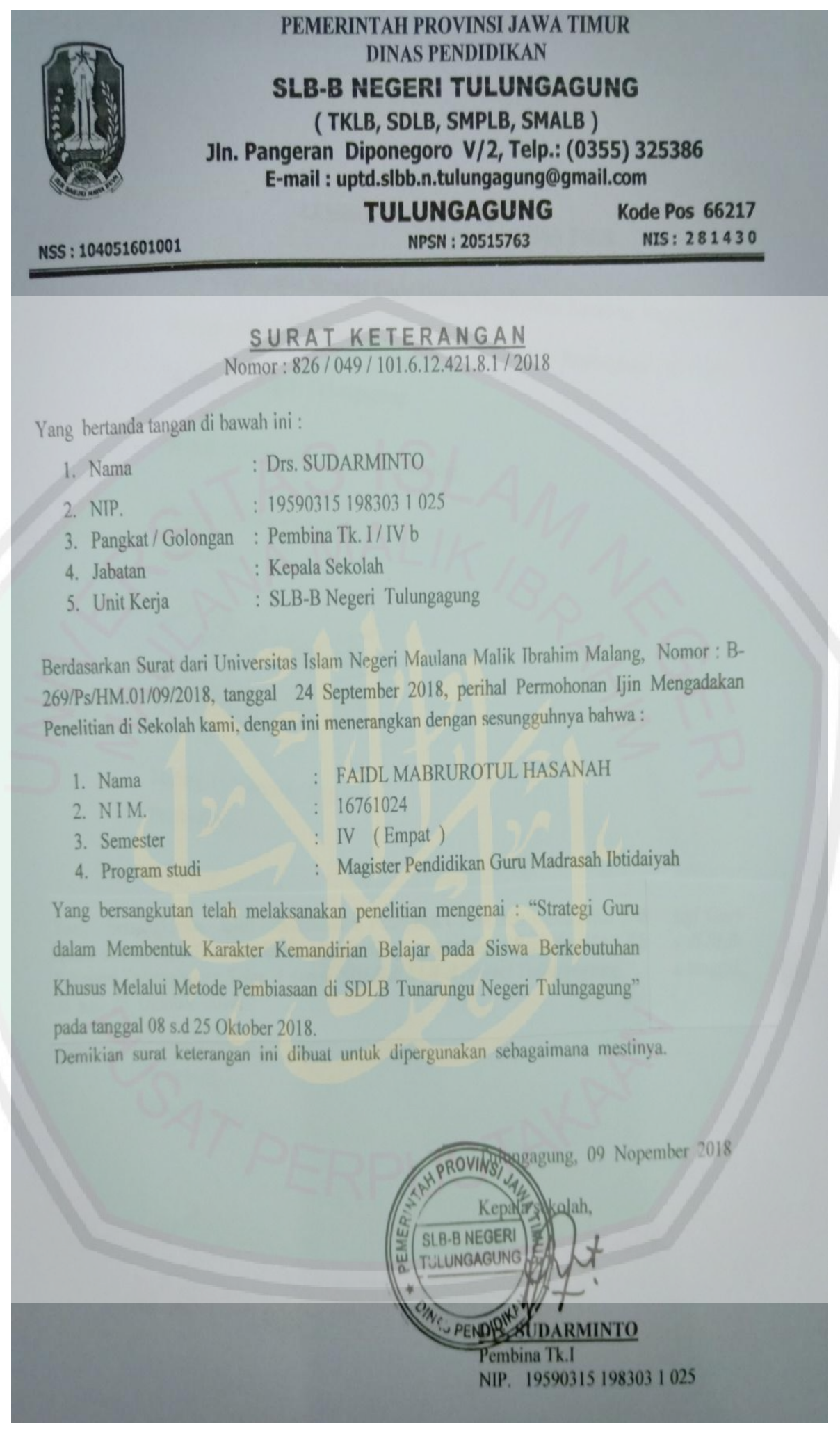




\section{BIODATA MAHASISWA}

$\begin{array}{ll}\text { Nama } & \text { : Faidl Mabrurotul Hasanah } \\ \text { Nim } & : \text { 16761024 } \\ \text { Tempat Tanggal Lahir } & : \text { Tulungagung, 30 April } 1990 \\ \text { Prodi } & : \text { Magister Pendidikan Guru Madrasah Ibtidaiyah } \\ \text { Alamat Rumah } & \text { : Desa Jeli Kecamatan Karangrejo Kabupaten } \\ & \text { Tulungagung } \\ \text { No HP } & : \text { O85749521208 } \\ \text { Email } & : \text { butterflayfla@yahoo.com }\end{array}$

\section{Jenjang pendidikan}

1. MIN Jeli Tulungagung

2. MTS Tribakti Kediri

3. SMA Islam Sunan Gunung Jati Tulungagung

4. S1 Pendidikan Guru Madrasah Ibtidaiyah (PGMI) STAIN Tulungagung

Malang, 14 Desember 2018

Mahasiswa,

Faidl Mabrurotul Hasanah 